\title{
The Cult Statues of the Pantheon
}

\author{
EDMUND THOMAS
}

ABSTRACT

This article reconsiders the possible statuary of the Pantheon in Rome, both in its original Augustan form and in its later phases. It argues that the so-called 'Algiers Relief' has wrongly been connected with the Temple of Mars Ultor and is in fact evidence of the association of the Divus Julius with Mars and Venus in the Pantheon of Agrippa, a juxtaposition which reflects the direction of Augustan ideology in the 20 S B.C. and the building's celestial purpose. This triple statue group became the focus of the later Pantheon, and its importance is highlighted by the hierarchized system of architectural ornament of the present building.

Keywords: Rome; Pantheon; Mars; Venus; Caesar; Augustan ideology; image; cult; twelve gods; divine statuary; sundial; architectural ornament

Everyone knows that the Pantheon in Rome is the best-preserved building from antiquity. Where, however, it is not at all well-preserved is in its statuary. In I 545 the last remaining trace, supposedly a bust of Cybele, was removed from its position in the wall of the chapel to the left of the entrance (Fig. I), which had become a 'rubbish dump' for fragments of the pagan building and two years earlier had been allocated to the Confraternity of Saint Joseph of the Holy Land, soon to become known as the famous Congregazione dei Virtuosi. ${ }^{1}$ The bust was thought to be 'something for gardens and not for holy places' 2 and was removed. ${ }^{3}$ Nothing is known about what happened to it after that. ${ }^{4}$ So, for moderns, the questions of which statues existed in the building and where they stood remain matters for debate. In a throwaway remark after a lecture at the Archaeological Society in Berlin in I867, Theodor Mommsen suggested that statues of the seven planetary divinities filled the seven exedras, a view which was immediately accepted by the lecturer Friedrich Adler. ${ }^{5}$ In 1906 the German ancient historian Heinrich Nissen looked more closely at the possible images that stood within the niches of the interior

\footnotetext{
1 Pasquali 2004: 37. Documents in Waga I992: 85-I 58.

2 Roma, Pantheon, Congregazione dei Virtuosi, Lib. I, fol. 3 r (I 543 ) (Census AAAKR, document I0563): 'Di poi si parlo infra li confratri se era bene o male che quella Cibele quale e nel muro della nostra capella vi stessi et fu resoluto non essere bene, anziche si levassi perche era cosa da giardini, et non da luoghi sacri ...'.

3 ibid., Lib. I, fol. I I v ( 5 October I 545): 'adi x d'Ottobre Quinto fu resolute che dalla nostra cappella si levassi quella testa di Cibele et quelli pesci, perche non vi stavan ben esendo cose de' tempi de' Gentili ...'.

4 Curiously, a bust of Cybele is recorded as having adorned the gardens of the Villa Grimani on the Quirinal before being donated in I $586 / 7$ to the Venetian Republic by Giovanni Grimani, Patriarch of Aquileia: Venice, Museo Archeologico, inv. V.3; Perry 1972: I2 I, no. 49, pl. 239. Grimani is reputed to have brought other statues from the Pantheon, including the marble standing statue of Agrippa now also in Venice, but both the provenance and identity of the latter figure are disputed: Romeo I998: I08.

Anon. I867: 55 .
}

JRS I07 (2017), pp. I46-2I2. (C) The Author(s) 2017. 
and proposed a reconstruction. ${ }^{6}$ Yet his reconstruction has not been widely accepted, and the question has not been pursued further. Indeed, thirty years ago, Paul Godfrey and David Hemsoll challenged the traditional identification of the building as a temple and argued that the principal round exedra facing the building's entrance was used not for statuary at all, but for a tribunal for the emperor. ${ }^{7}$ It can therefore no longer be taken for granted even that its statues were cult images.

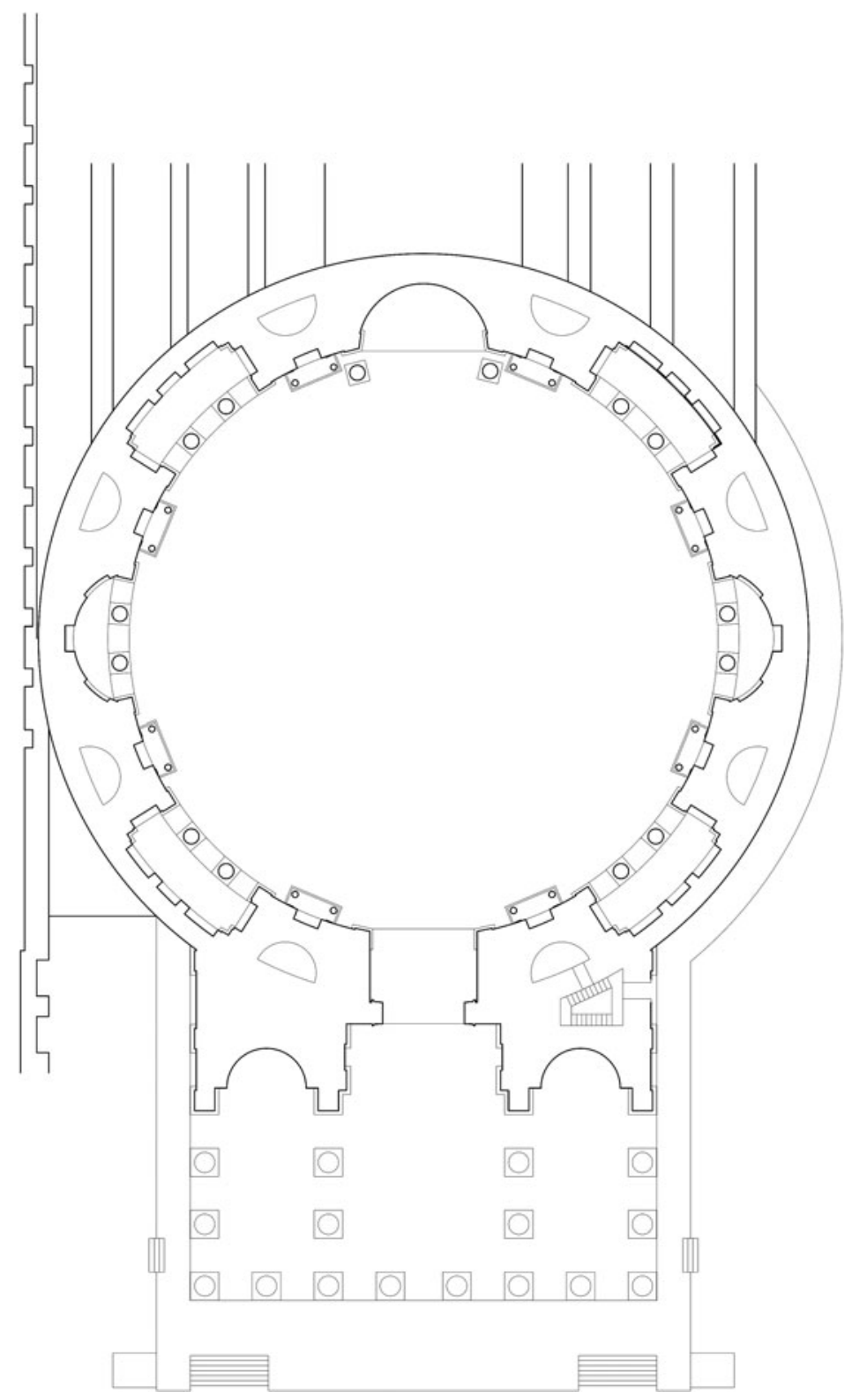

FIG. I. Plan of the Pantheon. (Drawing by Mark Wilson Jones, with his permission)

6 Nissen 1906.

7 Godfrey and Hemsoll I986. 
This article reconsiders the question and proposes a new reconstruction of the building's statuary. In so doing, it also reconsiders the statuary of the original building erected by Marcus Agrippa, overturns some accepted scholarly orthodoxies about the statuary of Augustan Rome, and throws light both on the evolution of Augustan ideology in the earliest phases of the régime and on the rôle played by the building and its statuary in the ideology of Hadrian and Septimius Severus.

\section{THE STATUES OF AGRIPPA'S PANTHEON: OF GODS AND MEN}

Cassius Dio's famous third-century account is the only ancient literary source which addresses the matter directly. His description of Agrippa's buildings is placed in Augustus' ninth consulship, in 25 B.C., directly after the wars in Spain and Germany, the successful conclusion of which resulted in Augustus closing the doors of the Temple of Janus. ${ }^{8}$ After mentioning the Poseidonion (Basilica of Neptune) and the Laconian Sudatorium (Agrippa's Baths), he refers to the Pantheon as follows:

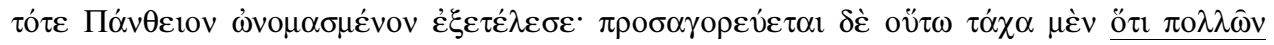

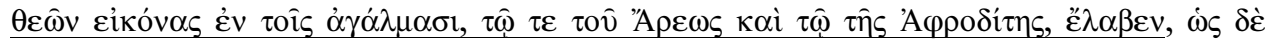

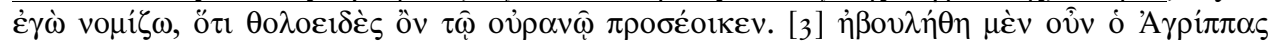

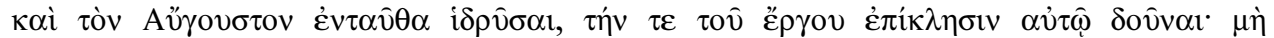

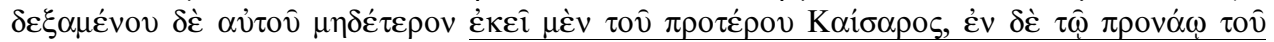

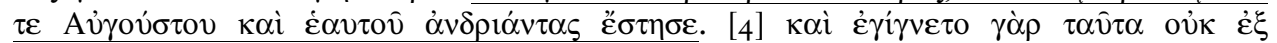

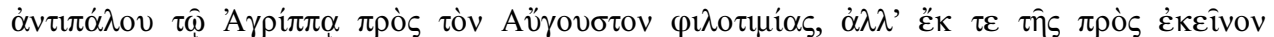

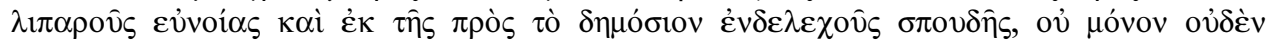
$\alpha$

At that time [Agrippa] completed the Pantheon ('all-divine') as it is called. It is known by this name, perhaps because it received images (eikonas) of many gods among the (cult?) statues (agalmata), that of Mars and that of Venus; but, I believe, because, being like a tholos, it resembles the heavens. [3] Agrippa, for his part, wished to place a statue of Augustus there too and to bestow on him the honour of having the structure named after him; but when the emperor would not accept either honour, he installed in that place a statue of the former Caesar and in the pronaos statues of Augustus and himself. [4] This was done, not out of any rivalry or ambition on Agrippa's part to make himself equal to Augustus, but from unctuous loyalty towards him and his incessant eagerness for the public good; Augustus, far from reprimanding him for that, honoured him all the more. ${ }^{9}$

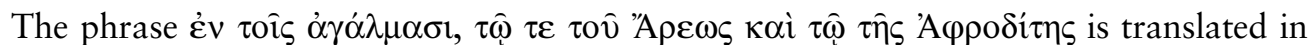
Cary's Loeb as 'among the images which decorated it (the statues of many gods), including Mars and Venus'. ${ }^{10}$ However, as Adam Ziolkowski has noted, this translation does not accurately render the peculiar syntax of the passage. ${ }^{11}$ The phrase $\tau \hat{\omega} \tau \varepsilon \tau o \hat{v}$

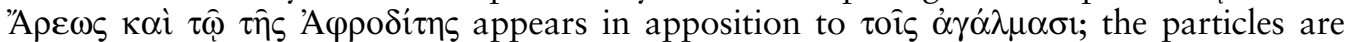
more straightforwardly translated, not as 'especially' (signalled by the $\tau \varepsilon$ after $\pi \mathrm{o} \lambda \lambda \hat{\omega} v$ ) or 'including', but as 'both ... and ...'. He therefore argues that the only true cult statues were those of Mars and Venus. But this translation draws attention to a second problem, the preposition '̇े before $\alpha \gamma \alpha \dot{\alpha} \lambda \mu \alpha \sigma \mathrm{l}$ : how can the 'many statues' be included

\footnotetext{
8 The date of 25 B.C. derived from Dio's narrative is corroborated by the reference on the frieze of the Trajano-Hadrianic building to Agrippa having served three consulships, the last of which was in 27 B.C.

9 Cass. Dio 53.27.2-4; author's translation.

10 Cary and Foster I9I7: 263.

11 Ziolkowski 2007: 469.
} 


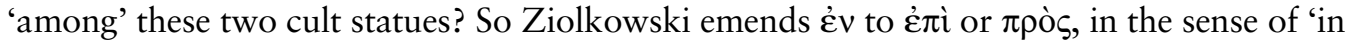
addition to', making the statues of the 'many gods' supplementary to the two cult statues of Mars and Venus. The solution is neat, but not unproblematic. Apart from the difficulty of making an unwarranted change to the text where the manuscripts are in full agreement, the emendation also gives a puzzling sense to this explanation of the building's name: if Dio means that the figures of Mars and Venus are the only cult statues and the images of many gods' are simply additional, the view that the building received its name from such supplementary statuary would have seemed less plausible. If, on the other hand, he was referring to images of many gods among the agalmata, highlighting those of Mars and Venus, this probably more widespread explanation of the name, that it was derived from its agalmata of 'all the gods', would be entirely understandable.

Nevertheless, the force of Ziolkowski's first point remains irresistible: it is indeed much

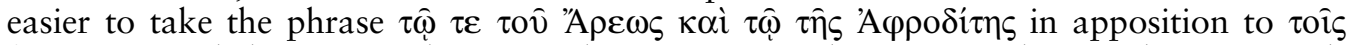
$\dot{\alpha} \gamma \alpha \dot{\alpha} \mu \alpha \sigma \mathrm{l}$ and thus to see these two deities, Mars and Venus, as the temple's main cult statues. That was exactly how Nissen interpreted the passage in his reconstruction of the building's statuary (Fig. 2). Taking the statues of Mars and Venus as the 'proper cult image of the temple (eigentliches Tempelbild)', he placed them accordingly in the central niche opposite the entrance. ${ }^{12}$ He filled the other exedras and intermediate tabernacles with other deities selected from the lists of gods in the Acts of the Secular Games of I7 B.C. - Jupiter Optimus Maximus, Juno Regina, Apollo and Diana ${ }^{13}-$ and in the various classifications of the Romans' penates by the late Republican authority Nigidius Figulus and the imperial antiquarian Cornelius Labeo (who include Neptune), Varro (who adds Minerva), and the Republican historian Cassius Hemina (who identifies them with the Great Gods of Samothrace); and he drew further support from the combatants at Actium described by Virgil on the Shield of Aeneas: Neptune, Venus and Minerva; and Mars and Apollo. ${ }^{14}$ The statue of Divus Julius Nissen assigned to the niche immediately to the right of the entrance, justifying this placement by the argument that it would have suited the orientation of his comet, on the western side of north. ${ }^{15}$ Other particular positions around the rotunda he assigned on the basis of orientation or simply proximity. He gave the position of precedence, in the aedicule to the left as one enters, to the goddess Salus because of her importance in the sacrifices of the Arval Brethren. ${ }^{16} \mathrm{He}$ was undecided whether or not minor deities stood beside the principal ones.

Most of this, of course, was pure speculation. What seems particularly anachronistic is that Nissen applied Dio's account of Agrippa's actions to the building as it appeared in the Bithynian senator's own time, after its rebuilding begun by Trajan and completed by Hadrian and its more recent restoration by Septimius Severus and Caracalla. Nissen infers that Dio was correct in his claim about the decorative scheme of Agrippa's building, but he also seems to assume that the same details were true of the building as it stood in Dio's own day. The use of texts about the gods of Augustan Rome to identify the contents of the Severan building, which consolidated the rebuilt Trajano-Hadrianic structure, is potentially problematic. On the other hand, there is no reason to disregard Dio's text altogether. The third-century senator is quite circumspect in what can be said about the statuary of a building destroyed over a hundred years previously. The only statues inside the cella that he names are those of Mars, Venus, and 'the former Caesar'; he leaves the identity of the others entirely vague. That guardedness is a reason for taking him at his word: those were either the only three statues which he knew to have been definitely present in Agrippa's building or at least

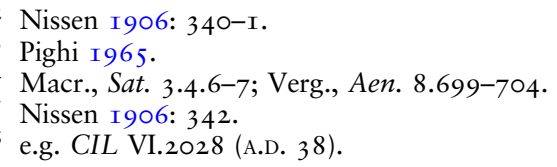




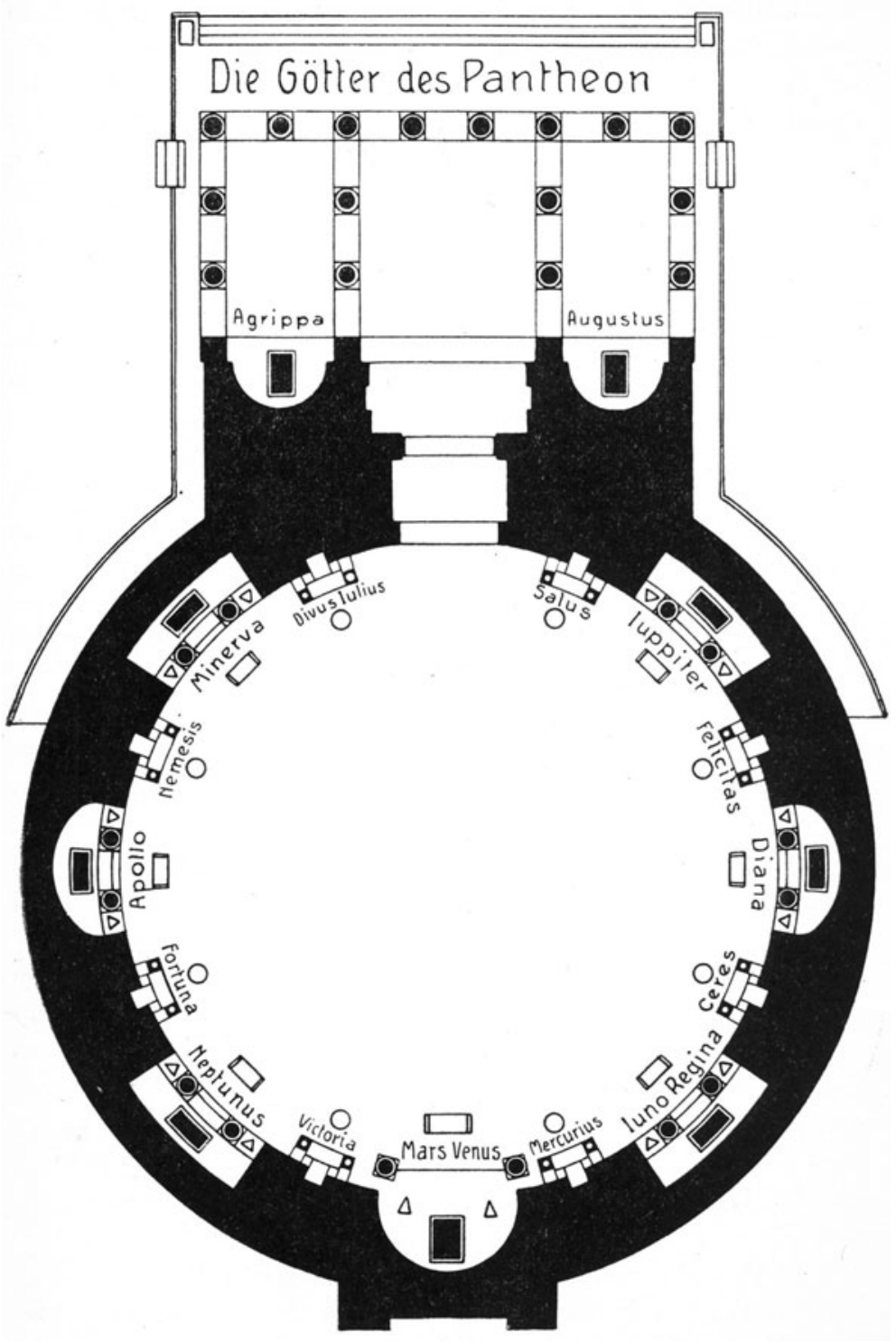

FIG. 2. Reconstruction of statues in Pantheon by Nissen. (From H. Nissen, Orientation (I894), 34I)

the ones most worth mentioning. One may wonder what grounds Dio had to be so certain that these statues had stood in Agrippa's Pantheon. Although he had arrived in Rome in A.D. I80, some twenty years before Severus' restoration of the building, he had no Roman ancestors who might have passed on memories of the Agrippan arrangement. His ten years of meticulous research for his history were based on reading the major historians, which for the Augustan era included Augustus' autobiography, but for the buildings of the past he more likely relied on oral report. As Fergus Millar wrote of Dio's account of the Theatre of Pompey: 'It is not surprising that stories should circulate about the foundation of a major public building which, as Dio says, was still in use. In considering the sources used by ancient historians, we perhaps underestimate the part 
played by the vague knowledge about figures and events in the past, and anecdotes and legends, which would be common to any given society.' 17

For a major monument like the Pantheon, associated with the first emperor, such oral stories were undoubtedly extensive. But they would have been particularly evident in A.D. 202, when Severus and Caracalla restored the building 'with all its decoration (cum omni cultu)'. ${ }^{18}$ The senator Dio was almost certainly present in Rome at that time, right in the middle of the ten-year period in which he was probably researching his history, and could hardly have ignored the ceremony or any reminiscences of the Agrippan building it may have prompted. It would have been natural to infer the identity of the principal statues of the Agrippan arrangement from what was clearly visible in his own day in the new Severan restoration for which continuity was so explicitly claimed in the inscription. But as he named only three figures - Mars, Venus and Caesar - one may assume that these were the most memorable statues, if not the most prominent, of the Agrippan building and that the others did not necessarily reflect the original arrangement, though they could still be considered agalmata. ${ }^{19}$ Stories about how this particular combination arose must have been widely circulated and will undoubtedly have contributed to Dio's understanding of Agrippa's Pantheon. The story of Agrippa's original intention to call the building after Augustus was just the sort of account that could have been passed on in this manner, and the possibility that another senator had communicated this to him, either from his own family knowledge or, in Millar's words, from his own 'historical or antiquarian reading', cannot be discounted. ${ }^{20}$

Dio's account of the Agrippan foundation cannot, then, be altogether dismissed. However, of the three statues that he names, Duncan Fishwick has argued that the statue of Caesar cannot have been a cult statue like those of the two Olympians. ${ }^{21} \mathrm{He}$ points to Dio's term andriantes, which seems to be distinguished from the eikones of the many gods and which Dio appears to use consistently in his work for statues of mortals, while for images of gods he uses agalmata. ${ }^{22}$ This follows what is often said about these terms, that andriantes and eikones usually refer to life-size, honorific statuary, whereas agalmata is used for religious images. For Fishwick, 'the statue of Caesar, far from being

17 Millar I964: 36.

18 Millar I964: I7; CIL VI.896.

19 Stewart 2003: 26: 'there is no distinction, not even a faint and flexible distinction, between cult statues and lesser images of gods: the word agalmata serves both.'

20 Millar I964: 37 .

21 Fishwick 1992: 329-36.

22 Andrias: 37.9.I (on the Capitol, unspecified, but distinguished from agalmata); 43.45 .2 (of Caesar); 44.4 .5 (of Caesar); 44.52.I (of Pompey); 46.33.2 (of the consul Vibius); 46.5I.4 (of Juventius); 53.22.3 (of Augustus); 53.27.3 (of Caesar and Augustus in the porch of the Pantheon); 54.I.I (in the Pantheon); 54.30.5 (of Augustus); 57.2I.3 (of men honoured by Tiberius including Sejanus); 57.24.7 (of Tiberius); 58.2.4 (in general, by contrast with living men); 59.26.3 (of Gaius); 59.30.1a (of Gaius); 60.5.4 (of Claudius); 60.6.8 (unspecified, returned to cities); 60.I3.3 (of Augustus); 60.22.3 (of the actor Mnester); 6I.I6.I-2a (of Nero and Agrippina); 62.8.5 (of the lyre-player Pammenes); 64.2I.2 (of Vitellius); 65.I4.5 (of Vespasian); 67.8.I (of Domitian); 68.2.I (forbidden, of Nerva); 68.15.3 (of Licinius Sura); 69.1 I.4 (of Antinous); 69.I8.I (of Turbo and Similis, under Hadrian); 70.2.I (of Pharasmanes of Iberia, an equestrian statue in the Temple of Bellona); 72.3 .5 (of Marcus Vindex); 72.II.I (of Victorinus); 72.I5.3 (of Commodus); 72.15.6 (of Commodus, in the form of Heracles); 73.I4.2a (of Severus, decreed by the Senate, but not accepted); 74.4.4 (of all the famous ancient Romans); 75.5.3 (adorning the pyre of Pertinax); 75.I2.5 (bronze statues thrown from the walls in the siege of Byzantium); 76.14.6 (of Plautianus); 77.II.2 (of Septimius Severus); 79.I8.I (gold and silver, melted down); 79.19.2 (dedicated by Tarautas to Alexander Severus and himself). Agalma: 22.76.2 (for Temple of Felicitas, I 42 B.C.); 37.9.I-2 (on the Capitoline, including of Jupiter, 64 B.C.); 37.I7.2 (no Jewish agalma of their god at Jerusalem); $37.34 \cdot 3-4$ (of Jupiter on the Capitoline, 63 B.C.); 38.17 .5 (agalmation of Minerva the Protectress dedicated on Capitol by Cicero, 58 B.C.); 39.I 5.I (of Jupiter on the Alban Mount, 56 B.C.); 40.I7.I (portent of sweating statues, 53 B.C.); 40.47.2 (portent of sweating statue, 52 B.C.); 42.50 .2 (collected by Caesar, as gifts, 47 B.C.); 43.35 .3 (portent of sweating statues, 45 B.C.); 43.45 .3 (of the gods in the Circus procession, 45 B.C.); 43.49 .3 (wooden statues from temples burned by Caesar, 44 B.C.); $45.17 \cdot 3$ (statue of Minerva the Protectress set up by Cicero, destroyed by storm in 43 B.C.). 
intended to receive cult, was purely honorific like the statues of Agrippa and Augustus in the pronaos' ${ }^{23} \mathrm{He}$ cites the Metroon at Olympia as a parallel, where a colossal statue of the deified Augustus, presented as Zeus, had replaced the cult statue of the Mother of the Gods, and was successively flanked along each side wall by imperial statues, which Pausanias refers to as andriantes; according to Fishwick, these were not intended to receive cult. ${ }^{24}$

However, the use of these terms is by no means cut-and-dry. The late Simon Price warned that, just as not all statues called agalmata were cult statues, so not all cult statues were called agalmata. To translate agalma as 'cult statue' 'misleadingly implies that all and only agalmata received cult'.25 Peter Stewart adds that, despite the restriction of the term agalma in imperial literature to divine statues, in inscriptions living men were 'not infrequently recipients' of what he calls 'honorific agalmata'. ${ }^{26}$ For the statues at Olympia, Pausanias' label andriantes simply reflected the fact that the sculptures were recognizably human portraits; it does not mean that they could not also be the object of cult. In fact, there is a particular edge to the terms used here which Fishwick overlooks. Pausanias' semantic distinction between the absent agalma of the Mother of the Gods and the present andriantes of the Roman emperors is tendentious, if not polemical, and thus hardly a good guide to the normative usage of these terms. ${ }^{27}$ The inclusion of the statue of Caesar among the agalmata of the Pantheon, both cult statues and lesser divine images, suggests that it could be seen in the same light; and Augustus' refusal to allow his own statue to be added there too suggests that he recognized this meaning.

Dio too could be aware of the slippage in the terminology that had come about in the radical changes at the end of the Republic. Nowhere is this clearer than in his account of the statues erected for Caesar in the final years of his life. He reported the honours decreed in 45 в.C. for the dictator Caesar: 'that an ivory portrait (andrias) of him, and later a whole chariot, should appear in the procession at the games in the Circus, together with the statues (agalmata) of the gods. Another likeness (eikon) they set up in the temple of Quirinus with the inscription "To the Invincible God" and another on the Capitol beside the former kings. ${ }^{28}$ A little later the andrias has become an agalma. Recounting the honours awarded in 42 B.C. for the now deified Caesar, Dio relates how the Romans 'laid the foundation of a shrine to him, as hero, in the Forum, on the spot where his body had been burned, and caused a statue (agalma) of him, together with a second image, that of Venus, to be carried in the procession at the Circensian games'. ${ }^{29}$ Similarly, he reports how, on the death of the young Antinous in A.D. I30, Hadrian 'set up statues (andriantes), or rather sacred images (agalmata) of him, practically all over the world'; this intimated Antinous' divinity, which, as with Caesar, Hadrian recognized to be confirmed by the 'star which he took to be that of Antinous'. ${ }^{30}$

\footnotetext{
23 Fishwick I992: 33 I-2.

24 Fishwick I992: 332; Paus. 5.20.9. For the argument that the statue of Augustus ( $\operatorname{lvO} 366)$ was dedicated before his death when the temple was still consecrated to the Mother of the Gods, as the inscription lacks the word $\theta \varepsilon$ ós, see Stone 1985.

25 Price I984: I78.

26 Stewart 2003: 25-6: 'First, like their Latin counterparts [signum and simulacrum], the words agalma and andrias are consistently distinguished in Greek literature of the Imperial period; and yet the epigraphic evidence from the Greek East reveals that living men were not infrequently recipients of honorific agalmata. Second, there is no distinction, not even a faint and flexible distinction, between cult statues and lesser images of gods: the word agalmata serves both.'

27 On Pausanias' disdain for the imperial cult, see Arafat I996: I 2 I.

28 Cass. Dio 43.45.2. Confirmed by Suet., Div. Jul. 76.I, who adds that the festival was the Parilia of 2I April; for the statue on the Capitol, see Cic., Deiot. 33-4, with Koortbojian 2013: 98 and 256-7, n. 23; Gradel 2002: 62-5 suggests that the inscription was 'to the Divine Caesar'.

29 Cass. Dio 47.I 8.4.

30 Cass. Dio 69.II.4.
} 
Certainly, the mere presence of a portrait statue in a temple did not necessarily mean that it was a cult object. ${ }^{31}$ In this respect, the statues of the divinized Caesar have long been a bone of contention. Stefan Weinstock denied their cultic aspect, but recently Michael Koortbojian has traced the subtle and complex process through which the civic portraits of Julius Caesar were replaced by or developed into cult images of the Divus Julius and goes a long way towards overturning that old orthodoxy. ${ }^{32}$ In particular, Koortbojian charts how between those first images of Caesar placed in a cultic context in 44 and 42 B.C. and the dedication of the Pantheon almost twenty years later the image of Caesar had developed into a form with recognizable divinity. The statue dedicated in 45 B.C. in the cella of the Temple of Quirinus, despite its inscription deo invicto, merely showed Caesar as Romulus, in military costume. But in 36 B.C. the coin types celebrating Octavian's inauguration of the Temple of the Deified Julius went further. Of the two types marking this event, one shows him in traditional, human dress as augur, the other as naked to the waist with the 'hip-mantle' wrapped around; a few years later, the same two types on the pediment of the restored Temple of Quirinus showed Romulus, like Caesar, as both mortal augur and divine Quirinus. ${ }^{33}$ In 29 B.C., a few years before the construction of Agrippa's Pantheon, the temple of the Deified Julius was dedicated in the Roman Forum. As Koortbojian concludes, it is hard to imagine that the precedent of the official cult statue would not have asserted itself and that, at the Pantheon, the new god would not have been represented similarly: that is, in the hipmantle, as he was depicted on what we have seen to have been the second of the images employed on the 36 в.с. coins depicting the as-yet-unbuilt Aedes Dives Iulii' ${ }^{34}$ So the statue of Caesar was not at all 'like' those of Agrippa and Augustus, as Fishwick claims, both by virtue of its position in the interior of the temple and because of its costume. This would have been no honorific appendage, but a leading cult object of the building. If in addition it was crowned by a star, the raison d'être of the statue's divinity would have been manifest. ${ }^{35}$

\section{THE 'ALGIERS RELIEF': DEBUNKING A MODERN MYTH}

Without any visual support this argument could be said to depend on probability and supposition. Yet there is one piece of evidence from Julio-Claudian iconography which encapsulates the three images which Dio attributes to Agrippa's Pantheon. A famous relief in the Museum of Antiquities at Algiers (Fig. 3) presents a group of four figures, three adults and one child: a female in full-length dress with a small nude boy playfully touching her with his sword; a bearded male warrior in full armour; and a heroized male figure with nude upper body and garment draped about the hips in 'hip-mantle' style, with a portrait head carrying features of the Julio-Claudian dynasty. ${ }^{36}$

31 cf. Cass. Dio 60.5.4, for temples that had become filled with portrait statues (andriantes) and votive offerings (anathēmata).

32 Weinstock I97I; Koortbojian 20I3: especially 94-I46.

33 Koortbojian 20I3: 9I-3.

34 Koortbojian 2013: 136.

35 As stressed by Koortbojian 20г 3: 86, the distinction was clear: 'men in the porch, gods inside'; and Caesar's divinity was 'a wholly different sort' of honour from those awarded to other humans (ibid.: I35).

36 Algiers (Icosium), Musée National Public des Antiquités, Grande Salle, no. 217; Doublet I 890: 84-5. 


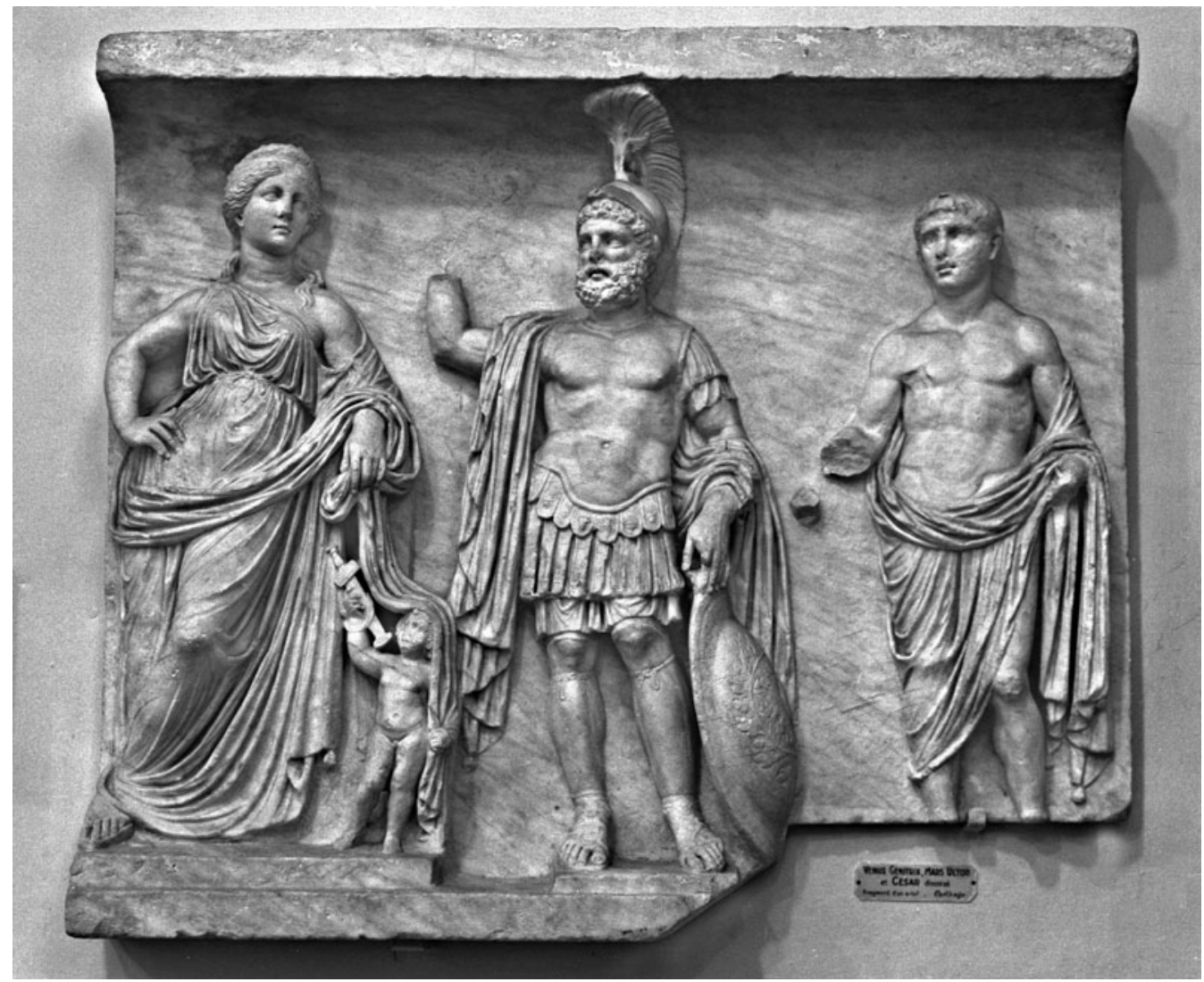

FIG. 3. Relief of figures, Museum of Antiquities, Algiers. (Photo: Forschungsarchiv für antike Plastik, FA 475-09, Arbeitsstelle für Digitale Archäologie, CoDArchLab Universität zu Köln)

In I 899 Stéphane Gsell argued that the central figure of the relief represented the cult statue of Mars Ultor. He recognized in it the figure identified two years earlier by Adolf Furtwängler, who, in his catalogue of the collection of the Belgian industrialist Léon de Somzée in Brussels, had noted the resemblance of a bronze statuette in that collection to this relief, the head of the Capitoline Mars in Rome (Fig. 4), and images on a Roman gem and on a coin of Antoninus Pius explicitly identified as Mars Ultor (Figs 5-6). ${ }^{37}$ The helmeted and armed appearance, the left hand of the figure resting on his shield propped up against his left leg, and the bent elbow of the right arm posed to hold a spear are all unmistakable correspondences between the statuette and the figures on the gem and coin which are shared by the figure on the relief. Gsell also drew attention to the wreath of oak leaves on the shield of Mars (Fig. 3) as an allusion to the corona civica awarded to Augustus in 27 B.C. He identified the female on the left side of the relief as Venus, with Cupid at her side, and in the right-hand figure he recognized a hole

37 Gsell I 899; I930: I77; Furtwängler I897: 59-63. The Collection Somzée was dispersed after the collector's death in I90I and the antiquities were sold in Brussels in I904. I have not been able to trace the present whereabouts of the statuette of Mars. For the gem formerly in the Marlborough Collection, see Boardman 2009: no. I4I. The wax impression illustrated here (Fig. 5) was made in the nineteenth century by Nevil Story Maskelyne, Keeper of the Department of Mineralogy in the British Museum, but the present location of the original gem is likewise unknown. 


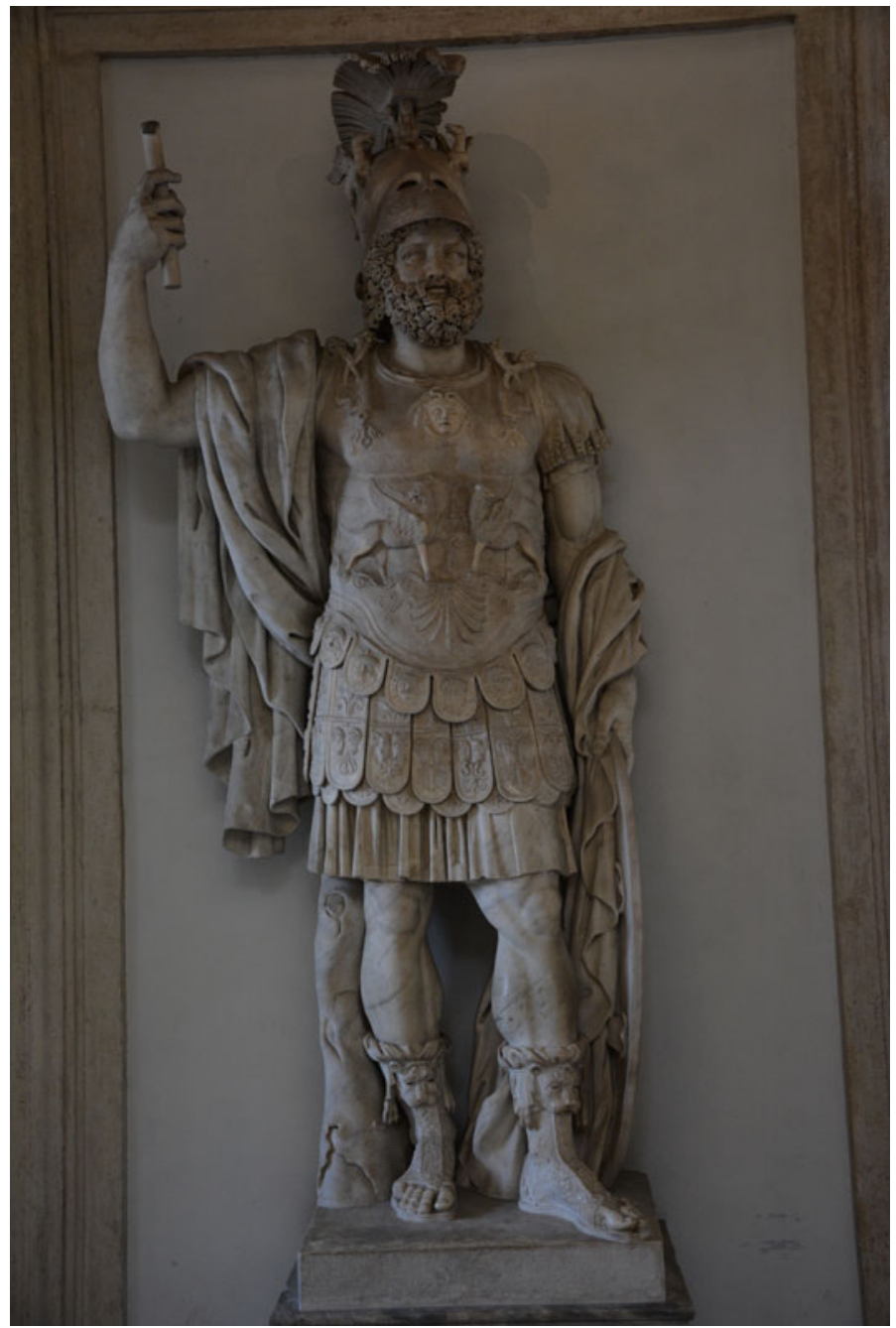

FIG. 4. 'Capitoline Mars', full view. Rome, Capitoline Museums, inv. no. MCoo58. (Photo: author)

just above its forehead in which was still embedded the traces of a metal fitting. Gsell argued that a star had originally been inserted here, which would have identified the figure of the original monument on which the relief was based as the divinized Julius Caesar, on whose statue Augustus claimed that he had placed a star 'soon' after the appearance of the comet in 44 B.C. ${ }^{38}$ His half-nude, 'hip-mantle' pose confirms the identification as a divine figure. This is supported by two coin types, issued by M. Sanquinius and L. Cornelius Lentulus: the first (Fig. 7) shows a bust of Caesar, with a young idealized face, surmounted by a star; the second (Fig. 8) shows Caesar in

38 Augustus, De vita sua fr. 6 Malcovati, in Pliny, HN 2.94; Suet., Div. Jul. 88. Cass. Dio 45.7.I adds that this was set up in the Temple of Venus Genetrix, rather than the Forum. Servius (ad Verg., Ecl. 9.46) locates such a statue on the Capitol, inscribed on the base 'to the demi-god Caesar (Caesari Emitheo)'. For discussion of which statue this was, see Koortbojian 20I3: 27-8. 


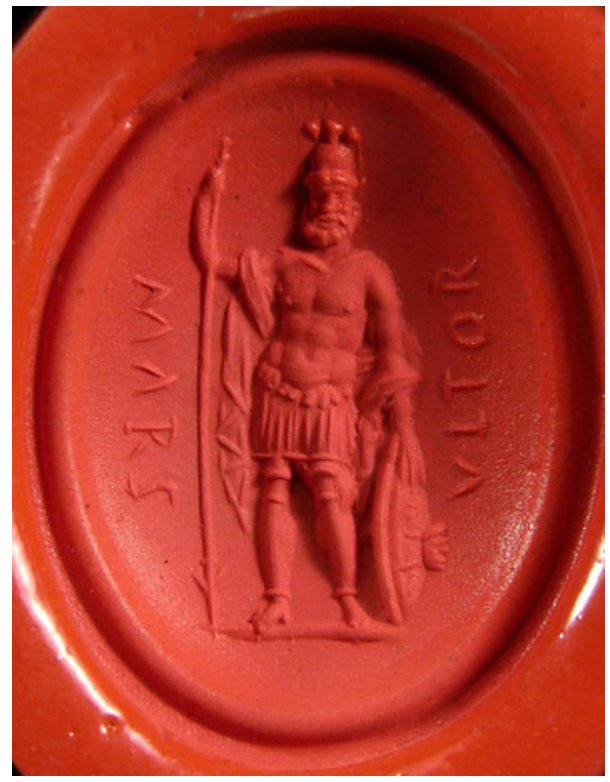

FIG. 5. Wax impression of the Marlborough Gem showing Mars Ultor, made in the nineteenth century by Nevil Story Maskelyne, and now in the Beazley Archive, Oxford. (Courtesy of the Beazley Archive, Oxford, with thanks to Claudia Wagner)

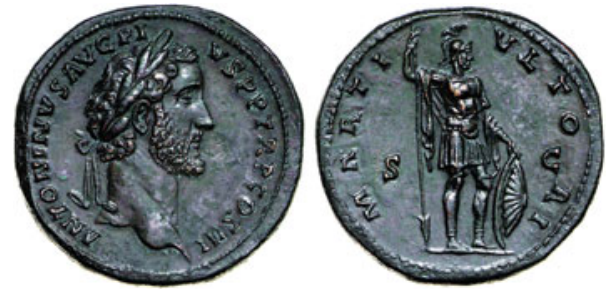

FIG. 6. Bronze sestertius of Antoninus Pius, with image of Mars Ultor: Berlin, Staatliche Museen, Münzkabinett I82042I7.

'hip-mantle' costume holding a small image of Victory (a victoriola) and crowned with a star by a togate Augustus who holds the Shield of Virtue. ${ }^{39}$ Yet, as no surviving statues bore either the star of the deified Julius or any of the crowns awarded to the mortal Caesar, it has been argued that, despite the early statements of Octavian in the Forum and the coin of 36 B.c. celebrating the promised Temple of Divine Julius, the star was not carried into the sculptural iconography of the posthumous Caesar until the Julio-Claudian reliefs, perhaps because in the first decade of Augustus' reign Romans were still uncomfortable with presenting Caesar's new divine status in this way. ${ }^{40}$
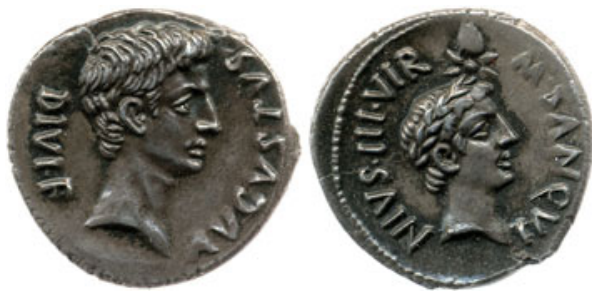

FIG. 7. Obverse and reverse of silver denarius in the name of M. Sanquinius, c. I7 B.C. (RIC I ${ }^{2} 338$; $B M C$ 70). London, British Museum, inv. no. R.6035.

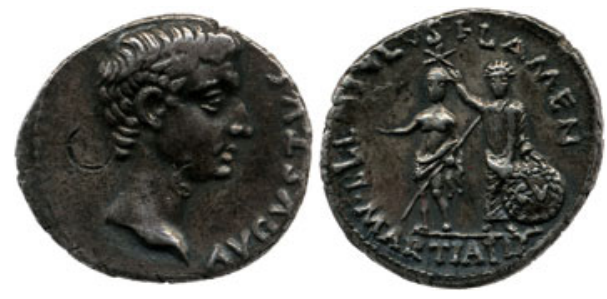

FIG. 8. Reverse of silver denarius in the name of

L. Cornelius Lentulus flamen monetalis (RIC I $\left.{ }^{2} 4 \mathrm{I} 5\right)$. British Museum, inv. no. 2002,0102.4978.

39 Sanquinius: RIC I², 66, no. 340; Lentulus: RIC I ${ }^{2}, 74$, no. 4I 5 .

40 Koortbojian 2013: I 2I-6, illustrating a bust in Turin where the earlier iconography with a crown had been mistakenly copied, leaving a strange crease in the back of the head. Gsell I899: 4I pointed to a bearded head of Egyptian black diorite in the Museo Barracco with a star at the centre of the diadem, which Barracco 
Nonetheless, despite the scepticism of some scholars, including Stefan Weinstock, and the vigorous criticism of others, especially Theodor Kraus, the identification of the figure on the Algiers Relief as the Deified Caesar is almost certainly correct. ${ }^{41}$ Kraus takes several lines of attack: (i) the portrait does not resemble other portraits of Caesar; (ii) no sculptures of Caesar survive with a star; (iii) someone else could have had the star (he suggests the Deified Augustus or Drusus, Nero, or Germanicus); (iv) something else such as a crown could have been fixed in the hole above the forehead; and (v) the three statues may have come from different monuments in Rome, though he offers no explanation why in that case they should have been united here. The lack of resemblance to other portraits of Caesar could be explained by a wish to render an idealizing depiction of the Deified Caesar that was distinctive from his life-time image. Kraus argues that the figure on the relief has the character of a portrait, not an idealization, with a recognizable Julio-Claudian hairstyle, but he balks at a particular identification, although others have proposed Gaius or Lucius, Nero, Marcellus, and Germanicus. ${ }^{42}$ But this apparent portrait aspect may also be the result of the artist of the relief having consciously or unconsciously tried to assimilate the figure to a contemporary Julio-Claudian prince. For the similarly heroized divine figure on the Ravenna Relief (Fig. 9), with a prominent star in relief on his forehead, and on the cuirass from Cherchell (Fig. IO), the Divine Julius remains the most likely identification. ${ }^{43}$ There is no independent evidence for anyone other than Caesar having a star on the forehead like this. But the strongest support for the identification is the juxtaposition with Mars and Venus.

believed was a portrait of Caesar, but is now believed to be a Ptolemaic portrait of a priest. Museo di Scultura Antica Giovanni Barracco, Musei in Comune, Inv. MB 3I, online at http://en.museobarracco.it/collezioni/ percorsi_per_temi/arte_egizia/testa_maschile_barbata (accessed 3I December 20I3). Kraus doubts Johansen's attribution of the 'Chiaramonti Caesar' in the Vatican, which shows unusually idealizing traits and may have been made after Caesar's assassination, perhaps c. 30-20 B.c. Vatican, Museo Chiaramonti 424B (http://mv. vatican.va/3_EN/pages/x-Schede/MPCs/MPCs_Salao4_02.html); Johansen I967: 21-2, pl. 22.

41 Alternative views: first, Langlotz I954: 3 I 8, then especially Kraus I964: 72, and, more extensively, I979; also Weinstock I971: 379; Simon 1963: I 5, n. 54; Fabbrini I961: I 56.

42 Gaius or Lucius: Simon I963; Zanker I968: I8-19, followed by Torelli I982: 78. Nero: Poulsen I958: I8990; Marcellus: Fabbrini I96I; Germanicus: Jucker I976.

43 Cherchell (Caesarea) (Algeria), Musée Archéologique, inv. I77. Ravenna, Museo Nazionale Archeologico. See the detailed photos by John Pollini, with text by Joe Geranio, at http://www.forumancientcoins.com/numiswiki/ view.asp?key=Julio \% 20Claudian $\%$ 20Portraiture $\%$ 20Ravenna $\%$ 20Relief, where the figure with star is identified as Germanicus. Kraus argued that the figure on the Ravenna Relief need not be Caesar and is overshadowed by Augustus and that it seems to show a different person from the figure on the Algiers Relief, which could have held a different attribute. Thus, he reckoned, if there are at least two individuals shown with stars on early imperial reliefs, it is no longer necessary to identify one as Caesar, especially if the portrait features do not suit. But this and his further argument that the Cherchell cuirass does not support the identification as Caesar, since it may be later in date, thus making other identifications of the 'Caesar' figure possible, are countered by Fittschen I976, who confirms the identification as Caesar and dates the cuirass to the Augustan period. 
The combination of these three figures led Paul Zanker to argue imaginatively that the relief depicted the cult statues of the Temple of Mars Ultor. ${ }^{44} \mathrm{He}$ interpreted the Capitoline statue of Mars (Fig. 4) as a copy of the Augustan cult statue of the temple. In Zanker's view, its iconography fits Augustan ideology well: paired griffins, animals of the revenge goddess Nemesis appropriate for Mars the Avenger; cornucopias on the shoulder pads, suggestive of the fruitfulness resulting from the Augustan Peace; and pegasi on the helmet, matching the Pegasus capitals of the Forum Augustum. Beside Mars on the relief (Fig. 3), he argued, was Venus Genetrix, and these two Julian gods were the perfect companions for the Deified Julius. The whole group indicated on the Algiers Relief, he suggested, would originally have stood on the $9 \mathrm{~m}$-wide podium at the back of the temple apse. This view became accepted scholarly orthodoxy. ${ }^{45}$

Doubts, however, remain. There are several important reasons for caution. First, the identification with an Augustan model for the Capitoline statue and for the figures on the gems is not without problems. The Capitoline Mars (Fig. 4), or 'Pyrrhus', as it was first identified after its discovery, is in fact a composite work resulting from a sixteenth-century restoration, undertaken for Angelo de Massimi and later brought to the Capitoline Museum in I736. ${ }^{46}$ A drawing by Maarten van Heemskerck, on fol. $27 \mathrm{r}$ of his Roman sketchbook, which was executed during his four-year stay in Rome between I 532 and I536 and is now in Berlin, shows the statue in the courtyard of the Casa Galli as a headless and armless torso. ${ }^{47}$ It was also drawn around the same time in the Lille Sketchbook. ${ }^{48}$ This torso sits oddly with a divine image and is more characteristic of imperial statues with paired facing griffins, as widely attested in the late first and early second centuries A.D. ${ }^{49}$ On this cuirass, the griffins turn their heads backwards, which is also true of one other statue, the portrait of M. Holconius Rufus, priest of the cult of Augustus at Pompeii (Fig. II); Zanker rightly compares the latter with the torso of the "Capitoline Mars'.50 Yet the Holconius portrait, 'the earliest securely dated and identified statue of a private person in cuirass that has been preserved in the West', is seen as 'sparked by imperial representation' and, given the office of the subject and his lack of active military experience, was more likely modelled on a portrait of Augustus than on a divine image as Zanker suggests. ${ }^{51}$

44 Zanker I969; developed in Zanker I987 and I988: I96-7.

45 Followed, for example, by Galinsky I996: 208; Kellum I997: I76; Pollini 20I2: I47; Tuck 20 I5: I26. Carandini 20I2: pl. 39A reconstructs the apse with just the statues of Venus and Mars from the relief, omitting the right-hand figure whom he identifies as the young Nero.

46 Bober and Rubinstein I986: 66-7, no. 24; 2010: 7 I-2, no. 24.

47 Berlin, SMBPK, Kupferstichkabinett: Heemskerck Album I, fol. 27 r. Illustrated in Bober and Rubinstein I986: fig. 62a; 20I0: fig. 62a. For the dating, see Veldman 20I2: II. Heemskerck left Haarlem after 23 May I532 (the date on his altarpiece of St Luke painting the Virgin, his leaving picture for his colleagues in the Haarlem Guild of St Luke) and was back in the Netherlands by 30 November I 537 (when he signed a contract for two altar wings in Amsterdam): Bartsch 20I 2: 30-I. Heemskerck's sketchbook is dated to I 535 or later by Hülsen and Egger I9I3I6: I, ix.

48 Lille, Musée des Beaux Arts, Lille Sketchbook, no. 786A. Attributed to Raffaello da Montelupo or Aristotile Da Sangallo. Catalogue des Dessins Italiens. Collection du Palais des Beaux-Arts de Lille, ed. B. Brejon de Lavergnée (Paris and Lille, I997), 3 Io no. 774.

49 Stemmer I978: I 53-4. Among the decorated cuirasses collected by Stemmer, the only two with a divine subject are the Capitoline 'Pyrrhus' and a similarly spurious composite work in Naples with restored head added to an antique torso (Museo Nazionale Archeologico 6I24; Stemmer I978: 8, no. I.3). By contrast, ancient representations of Mars show an undecorated cuirass.

50 Naples, Museo Nazionale Archeologico 6233; Zanker I988: 328-9 with fig. 259.

51 Fejfer 2008: 2I2, who nonetheless accepts Zanker's argument that the statue type reflects the cult statue of Mars Ultor, an assumption which gives the presumed date for the statue of after 2 B.c. The type was reproduced in replicas of later date, e.g. St Petersburg, State Hermitage Museum GR 3065 (Trajanic/ Hadrianic); see Stemmer I978: I40, n. 489. 


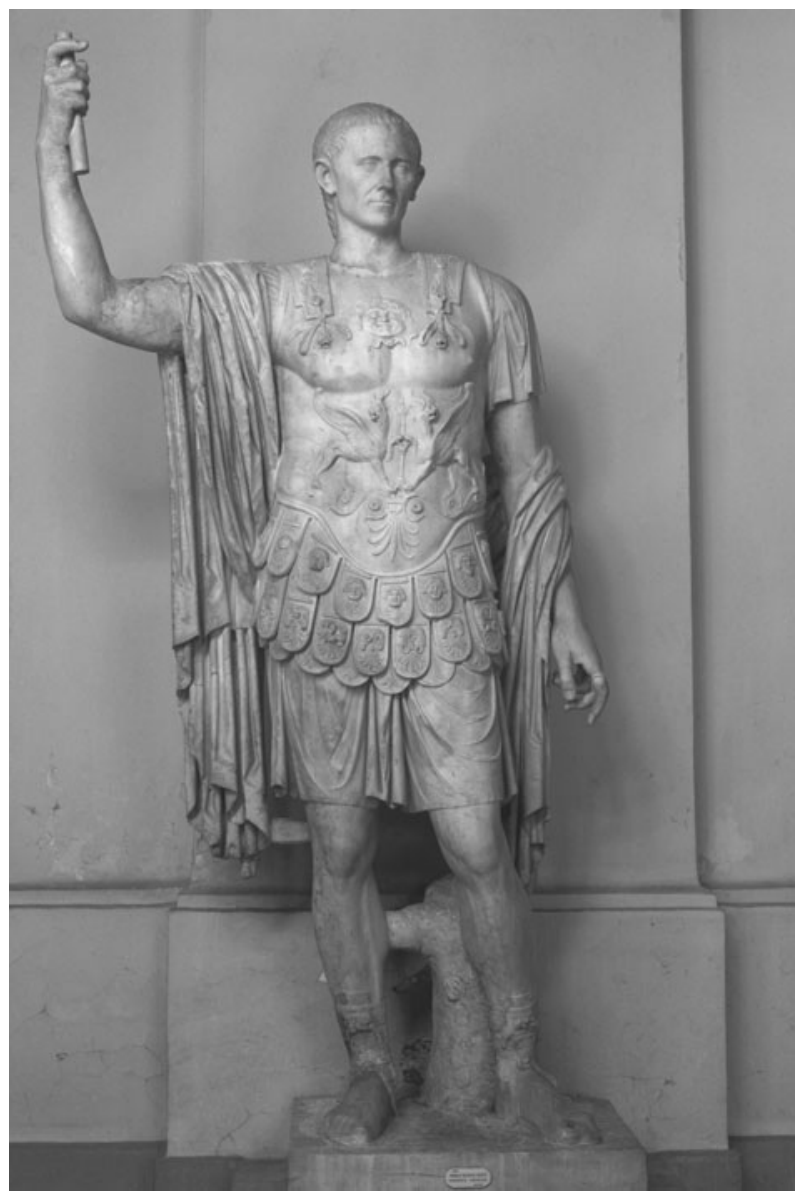

FIG. II. Statue of Holconius Rufus, Museo Nazionale Archeologico Naples. (Photo: German Archaeological Institute Rome, neg. no. 74.I288/9)

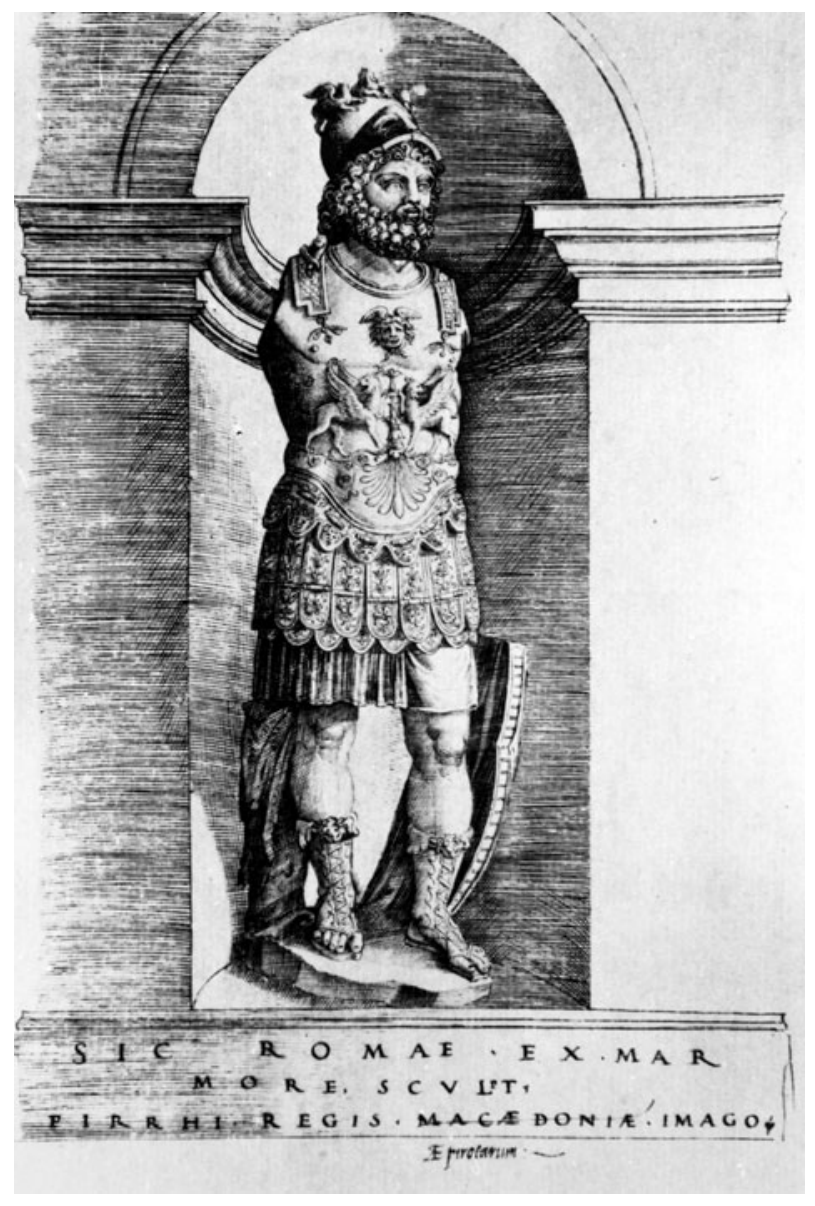

FIG. I2. Drawing of the statue of 'Pyrrhus' by Francisco De Holanda, Antigualhas, fol. 27r, Madrid, Real Escorial. (Photo: Warburg Institute) 
By March I 540, as a drawing by Francisco de Holanda indicates (Fig. I 2), the torso had been joined to a head bearing a helmet adorned with pegasi and a sphinx, and thick legs wearing buskins decorated in relief, and was identified as Pyrrhus, King of Epirus; it was placed in a round niche in the courtyard of the new Palazzo Massimo on the Via Papalis in the Campus Martius. ${ }^{52}$ The head itself had also been repaired: both the nose and the end of the helmet are modern (Fig. I3). The statue is later shown as fully restored in Antonio Lafréry's Speculum Romanae Magnificentiae (I 575) after a drawing of I 562 by Antonio Salamanca (Fig. I4), with both arms added, the left hand now resting on his shield, and a flamboyant plume added to the crest of the helmet: ${ }^{53}$ the resulting sculpture (Fig. 4) has been described as 'a muscle-bound brute ... almost a modern Hollywood figure, a sort of stocky Arnold Schwarzenegger'. ${ }^{54}$ These last additions must have been made at the latest by I549-50, when Ulisse Aldrovandi on his visit to Rome saw the statue at the head of the courtyard of the house of Angelo de Massimi near Campo de' Fiori. Recording his visit six years later, he described it as 'intiera' and noted that de Massimi had acquired the statue 'a short time ago' for 2,000 scudi. 55

The head was first recognized as an 'ideal' work without portrait features by Johann Winckelmann, who identified the figure as Zeus Stratios. ${ }^{56}$ It was subsequently interpreted by Furtwängler as an example of the Mars Ultor type, on the grounds that the basic form of the helmet recalls a Greek model of the early fourth century B.C. which would suit the classicizing tendency of Augustan sculpture, although he noted that the hairstyle and drill work were more characteristic of the late Trajanic or early Hadrianic period, so that the work would have to be a later copy of an Augustan original. ${ }^{57}$ The identification as Mars was subsequently supported by the head of the Mars on the Cancelleria reliefs, rediscovered in 1937-39 and now in the Vatican Museums (Fig. I 5), which likewise bears a helmet with plume, supported by a crouching winged creature, plausibly a pegasus, and has a beard with similar corkscrew curls; this parallel, and the echo of Flavian female hairstyles, modify the dating to the Flavian period. ${ }^{58}$ Although Furtwängler was more equivocal about the association of the head of the 'Capitoline Mars' with its torso, the most recent discussion by Ulrike Müller follows other scholars in inferring from the similar crystalline white marble of head and torso that they belonged to the same statue. In her view, the form and dimensions of the two parts of the neck are 'virtually identical'; 59 but this is much less clear-cut. The clumsy insertion of a thick layer of plaster (Fig. I6) conceals the different widths of the two parts, with the head set slightly lopsidedly to the viewer's left, and the divine head seems too big for the imperial torso which it joins.

\footnotetext{
52 Real Monasterio El Escorial, Antigualhas, fol. 27 r. Vermeule I956: 37, n. 2 I gives details of the Renaissance circumstances surrounding the head. Holanda was in Rome from September I 538 to March I540: Bury I98 I; Deswarte I996; Bartsch 2003: II 5.

53 Lafréry I 575: [30]. Daly Davis I994: II9.

54 Rockwell 2003: 77, who, however, wrongly attributes the decisive transformation of the figure to the eighteenth-century restoration by Pietro Bracci.

55 U. Aldovrandi, 'Le Statue di Roma', in L. Mauro, Le Antichità di Roma (2nd edn, Rome, I 556), I68-9.

56 Heenes 2003.

57 Furtwängler I 897 .

58 Müller I982: 136-7.

59 Müller I982: I37, following Jones I912: 39, no doubt influenced by Amelung's slightly more detailed assessment in Helbig I9 I2. But Furtwängler I 897: 63, n. 88, citing Hauser, is more sceptical.
} 
Müller argues that the circumstances of the rediscovery of the torso provide corroboration that it belongs with the head. Sallustio Peruzzi annotated his drawing of the Forum of Nerva (Fig. I7) with the comment 'here was found in our life-time through Angelo de Massimi the statue of King Pyrrhus which now stands in the house of his sons' ${ }^{60}$ Some have questioned this statement because it appears to contradict both Aldrovandi's claim that de Massimi had purchased the statue and Heemskerck's drawn testimony that the torso was already in the Casa Galli. ${ }^{61}$ Müller, however, notes the high price paid by de Massimi according to Aldrovandi, which she assumes to be for the torso, and argues that he was willing to pay such an enormous sum because he had already found the head in the same location. 62 She thus ingeniously reconciles Sallustio's annotation with the other evidence, arguing that it was the head which had been found in the forum by de Massimi. By combining head and torso de Massimi was able to make the resulting work the centrepiece of the courtyard of his new palazzo, one of the three new palaces of the de Massimi family created after 1532, designed for Angelo by Giovanni Mangone beside the more celebrated Palazzo Massimo delle Colonne on the Via Papalis. ${ }^{63}$

It has recently been suggested that Heemskerck's drawing is in fact a composite of two different views drawn in inks of slightly different colour, one showing the 'Pyrrhus' torso and the other the Galli collection, and there is no other evidence among sixteenth-century reports that the torso was ever in the Casa Galli. ${ }^{64}$ This in itself is no obstacle to the view that Angelo de Massimi was the finder of the statue, but that does not mean that head and torso had been found in the same place. When work started on de Massimi's new palace the sculpture was just a torso, yet within a few years it had become joined to the head. Müller's suggestion that de Massimi had somehow in his possession a head retrieved years earlier from the same place as the torso seems an improbable, and unattested, coincidence. But where did the head come from?

\footnotetext{
60 Florence, GDSU A 687v, in Bartoli I9I4-22: IV, pl. CCCLXXVI fig. 653 and Viscogliosi 2000: I 89-93, no. 50 : 'hic temporibus nostris inventa fuit statua Pirri regis per Dominum Angelum de Maximis quae nunc (e?)stat in Domo filiorum.' In the transcription by Bartoli I9I4-22: VI, II6, followed by Viscogliosi 2000: I90, the final verb is read as 'estat', a later Latin form of 'stat', since the initial 's' seems to be preceded by a curved stroke, which is absent in 'statua' three lines above and is recognized as an initial ' $\mathrm{e}$ '; this reading, however, is uncertain as it is not clear that this curve is a separate letter, rather than the initial stroke of the 's'.

61 Bober and Rubinstein I986: 66; 20I0: 7I. They suggest that the torso had been in the Casa Galli since the late fifteenth century, long before the excavation of the forum and before it was in the de Massimi house. Flaminio Vacca later reports the discovery of figured capitals suggestive of Mars under the Casa Galli, but does not mention the statue. Vacca, Mem. 30 ('Sotto la casa dei Galli nella via de Leutari di fianco alla Cancelleria mi ricordo vedervi cavare Vi furono trovati certi capitelli scolpiti con targhe, trofei e cimieri, che davano segno vi fosse qualche tempio dedicato a Marte'); Aldrovandi I 556: I68. Cited by Lanciani I902: I72-3.

62 By way of comparison, in I 556 the Cardinal of Paris Jean du Bellay was able to acquire the whole collection of the Milanese merchant Pietro della Stampa for just I, 00 scudi, half the amount allegedly paid by de Massimi; the collection included thirty-two complete statues, forty-one busts with heads, forty-two assorted heads, and thirty-one headless busts and torsos: Cooper 20I3. Yet the prestige of the 'Pyrrhus', in terms of artistic quality, findspot and state of preservation, should not be under-estimated and could explain why it commanded such a high price.

63 For details of the palaces of the de Massimi family, see Cafà 2004.

64 Bartsch 2007: 29-30. Christian 20I 2: I37-8 observes that Heemskerck's placing of the 'Pyrrhus' torso to overlap a torso in the Galli garden both creates the illusion that they occupy the same space and suggests the massive scale of the 'Pyrrhus'.
} 


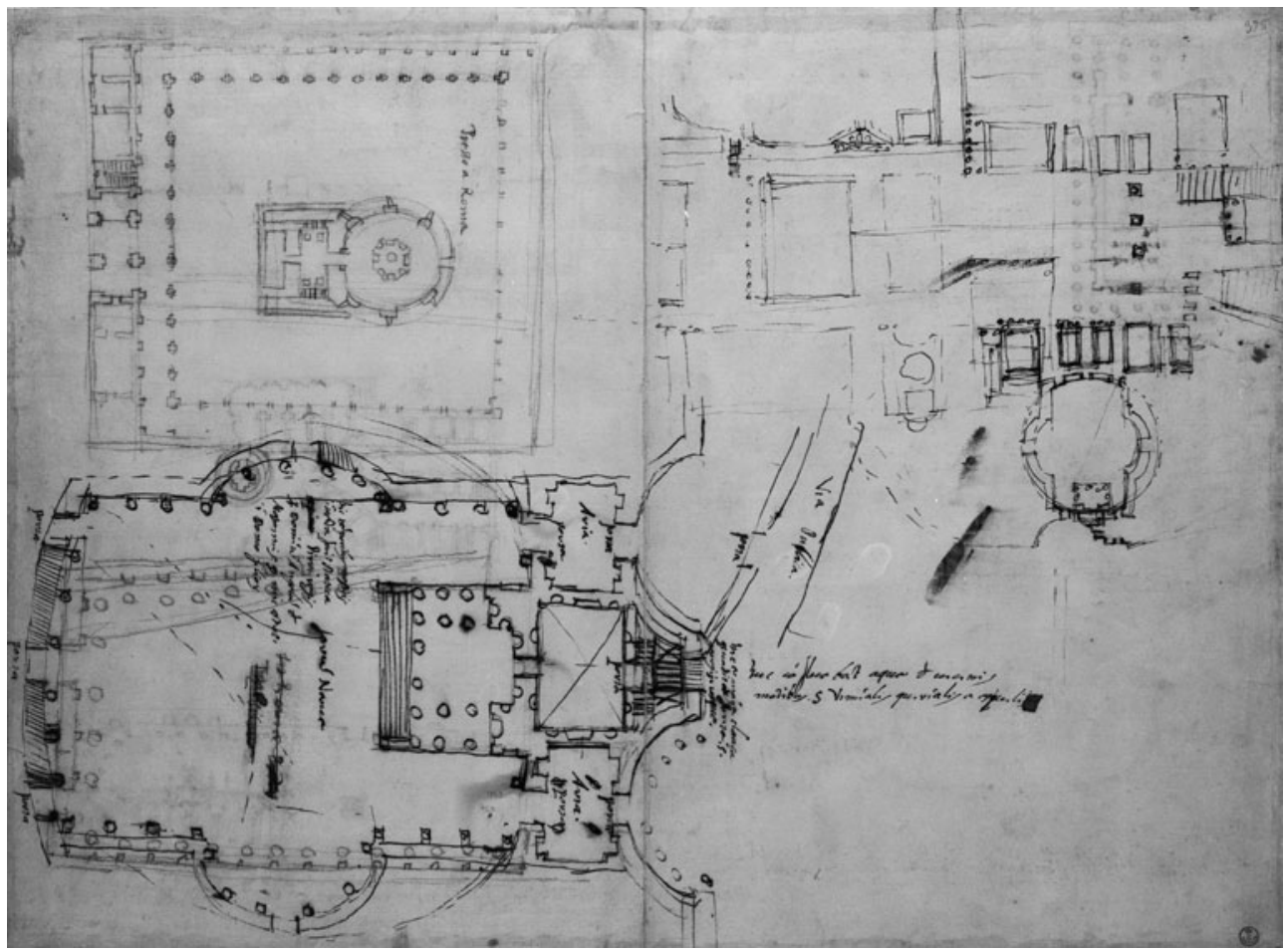

FIG. I7. Sallustio Peruzzi, drawing of the Forum of Nerva. Florence, Uffizi, UA 687 r.

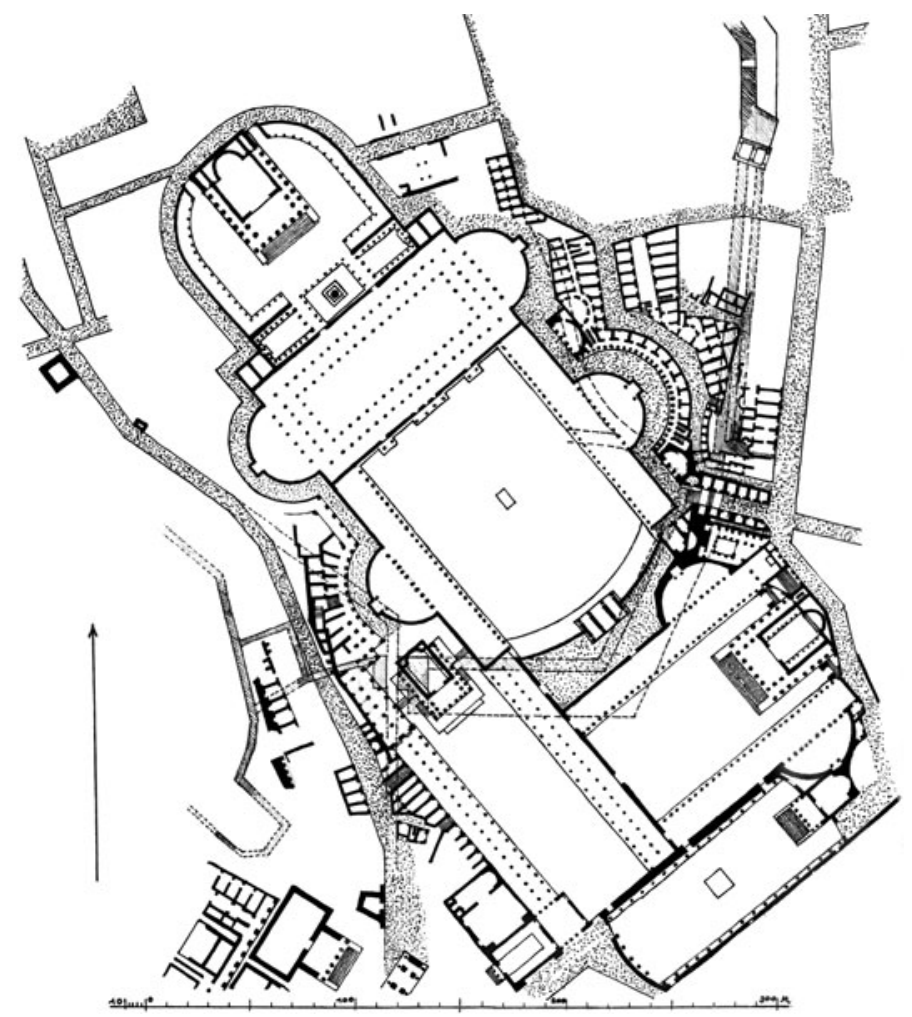

FIG. I 8. Complex of the so-called Imperial Fora, lower right corner: plan of the Forum Transitorium. (German Archaeological Institute Rome neg. no. 39.880R) 
There are some oddities about Sallustio's drawing (Fig. I7). The plan of the temple resembles the surviving remains in the Forum Transitorium (Fig. I8), except for a second row of inner columns, while the partial plan of the forum seems to show the detached colonnade of the 'Colonnacce'; but in the lower half of the drawing a pencil reconstruction with straight colonnades is oddly replaced by one with two rounded exedras on either side. ${ }^{65}$ The juncture with the Porticus Apsidata is similar, but not exactly as the archaeology shows, and there are two rectangular halls at the end of the colonnades. Some of these oddities can be explained by the fact that by the time Sallustio made his drawings, no earlier than 1553 when Angelo de Massimi died as he refers to the house being in the possession of his sons, buildings had been constructed over the southern hemicycle of the Forum Augustum which were not demolished until I 888-89. ${ }^{66}$ Unaware of the abutment of this hemicycle against the temple of the Forum of Nerva, Sallustio produced a sketch 'from memory', reconstructing the Forum of Nerva first in pencil with a rectilinear colonnaded court repeating the still preserved line on the opposite side of the temple, and then, in ink, with two facing curved exedras at the centre of the sides of the court. Alessandro Viscogliosi, therefore, argues that Sallustio cannot have seen the drawing of the Forum Augustum drawn many years previously by Antonio da Sangallo the Younger, in which this abutment was clearly shown (Fig. I9). ${ }^{67}$ Yet Sallustio's own sketch of the Forum Augustum, which was the basis for Antonio Labacco's fully elaborated drawing of 'the Forum of Trajan', seems based on more extensive drawings of the forum by Antonio da Sangallo and on a reconstruction of the temple by his father Baldassare whose drawings he must have inherited along with the rest of his sketchbook on the latter's death in I537; but both earlier artists omitted the relation to the Forum of Nerva. ${ }^{68}$ Certain features of another sketch by Antonio, which shows the southern side of the Forum of Nerva falsely labelled as the 'Foro Troiano' (sic) (Fig. 20), are replicated by Sallustio, particularly the peculiar articulation of the wall between the cella and the pronaos of the temple with an apse which is not shown elsewhere. ${ }^{69}$ Viscogliosi argues that the resemblance between the sketches of Antonio and Sallustio was because they had independently noted this feature at a time when the condition of the temple allowed this to be seen, but this is unlikely since Sallustio's drawing was made more than thirty years after Antonio's. It is quite likely, in fact, that Sallustio had seen Antonio's drawings as his father belonged to the same circle, and both Baldassare and Antonio were employed by the de Massimi brothers for their new palaces. But as the only part of the Forum Augustum shown on Antonio's drawing (Uffizi II23v, Fig. I9) which presented its abutment against the Forum of Nerva was precisely the southern hemicycle no longer visible to Sallustio, there was no reason for him to connect it with Antonio's other drawings of the Forum Augustum. Instead, Sallustio started by expanding Antonio's fuller drawing of the Forum of Nerva (Uffizi II2IV, Fig. 20) following the articulation of the front wall of the cella and the rectilinear colonnade of the forum, but then replaced his original sketch with a fantastic design consisting of two hemicycles that roughly transferred Antonio's design of the Forum Augustum (Fig. 2I) to the Forum of Nerva.

\footnotetext{
65 Florence, Uffizi, GDSU, inv. A 687 v; Viscogliosi 2000: I89-93, no. 50.

66 Viscogliosi 2000: I92. These were the properties of Cosciari, visible in the drawing by Dosio of this side of the Forum of Augustus (Florence, GDSU A 25 I 5 = Viscogliosi 2000: 229, no. 80, fig. I87).

67 Florence, GDSU, A I 123 ; Viscogliosi 2000: I92; cf. I25-8 no. IO.

68 Florence, GDSU, A 676 r; Bartoli I9 I4-22: VI, I 25. Libro d'Antonio Labacco appartenente a l'architettura nel qual si figurano alcune nobili antiquità di Roma (I 5 52), 3-4; derived from this, the I 569-70 drawing of Palladio, published in Quattro Libri dell'Architettura (I 570), IV, ch. 3I; cf. Ganzert I996: 27-3 I.

69 Florence, GDSU, A I I2IV; Viscogliosi 2000: I33, I92; cf. I3 I-4, no. I 2.
} 


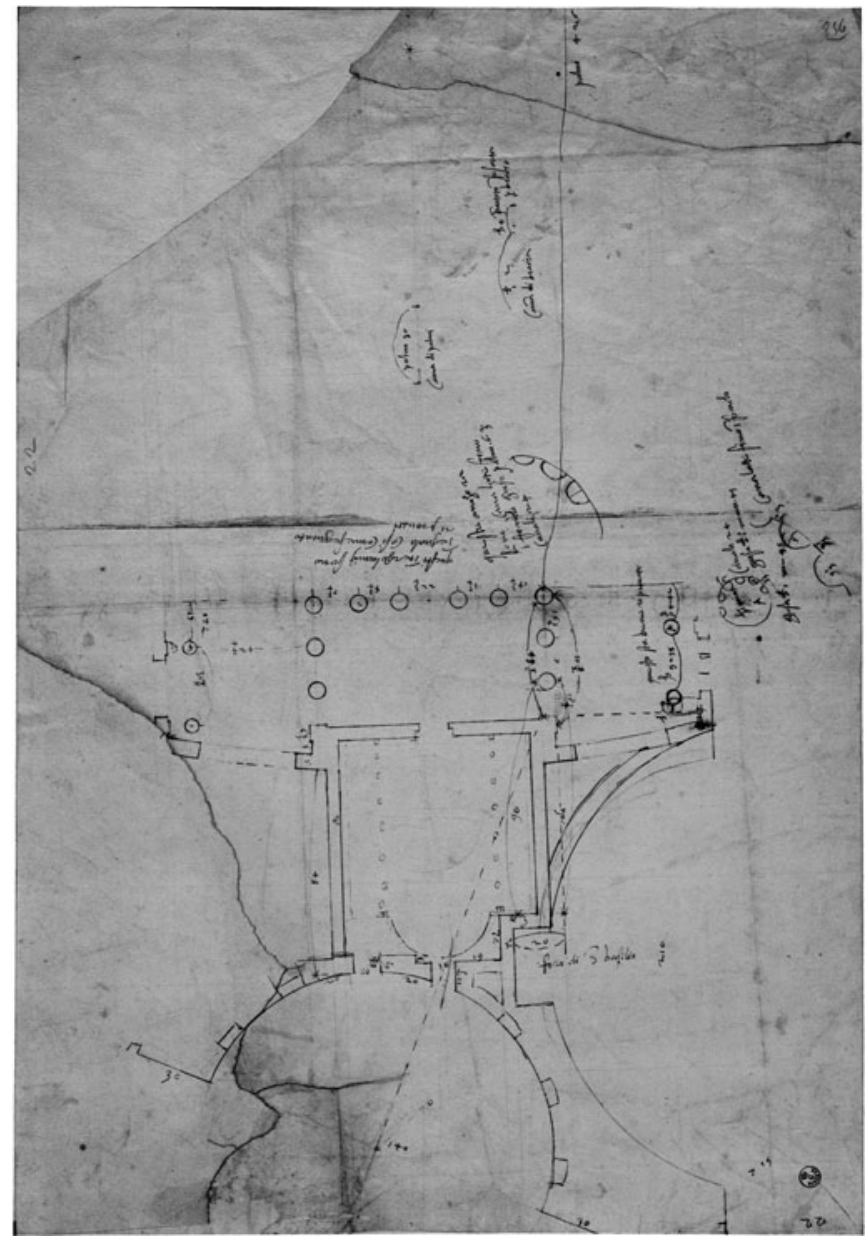

FIG. I9. Drawing of the Forum Augustum by Antonio Sangallo the Younger. Uffizi, UA I I23v.

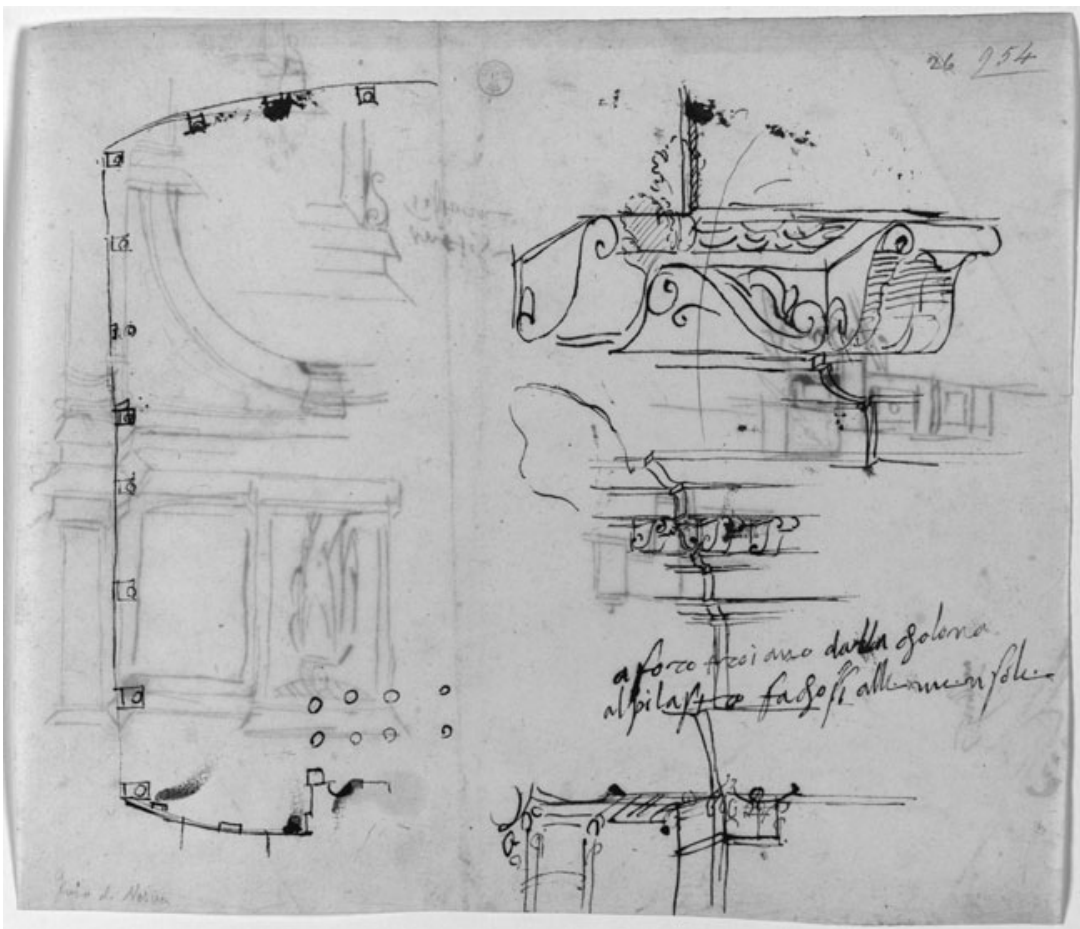

FIG. 20. Drawing of the Forum of Nerva ('Foro Troiano' [sic]) by Antonio Sangallo the Younger. Uffizi, UA I 22 IV. 


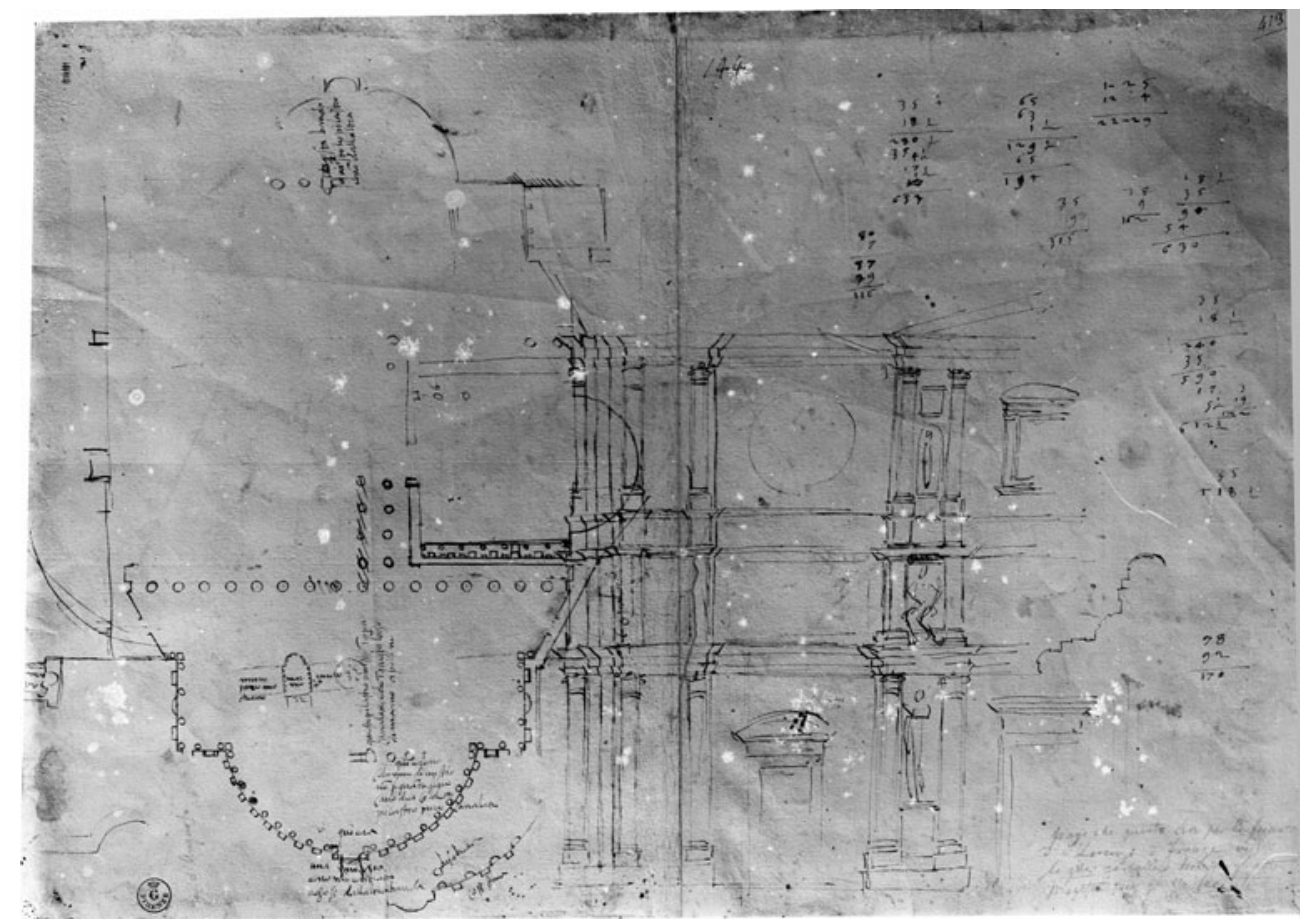

FIG. 2I. Drawing of the Forum Augustum by Antonio Sangallo the Younger. Uffizi, A 79or.

The hemicycle fronted by columns is drawn much more crudely in Sallustio's sketch (Fig. I7), but a further detail which he borrowed from Antonio's earlier drawing of the Forum Augustum (Fig. 2I) is a square base between two columns at the top end of the hemicycle, which is not mirrored at the opposite end of that hemicycle or in either end of the hemicycle opposite. ${ }^{70}$ Antonio placed a second square at the corresponding point at the other end of the hemicycle, but Sallustio placed just one. At this point, beside this non-existent left-hand exedra of the 'Forum of Nerva', a small line leading from Sallustio's annotation about the discovery of the statue of Pyrrhus (sic) to the column beside this square base appears to give the findspot of the statue. This is puzzling, not only because the statue was not found in one piece, but also because this exedra did not exist in the Forum of Nerva. Sallustio's location of the statue here can only be explained by a misinterpretation of the square base on Antonio's drawing of the Forum Augustum. As head and torso were not found together, it is possible that one of these objects was indeed found in the Forum of Nerva, but the other had been found at the end of the southern hemicycle of the Forum Augustum, no longer visible in Sallustio's day. Sallustio's drawing brought them together in one place in his falsely reconstructed Forum of Nerva. But there is another reason to believe the head may have originated in the Forum Augustum. As noted above, the bearded and helmeted head closely resembles the Mars on Relief A from the Cancelleria (Fig. I 5). That relief shows the profectio, or departure on campaign, of Domitian, accompanied by Mars and Minerva. It is well-known that such departures took place from the Forum Augustum. ${ }^{71}$ The plume of

70 Florence, GDSU, A 79or; Viscogliosi 2000: I I 6-2 I, no. 8. Sangallo's drawing was done before I 5 I 7 , before the construction of the Cosciari buildings over the southern hemicycle: Frommel I994: 55, n. 209.

71 Sumi 2005: 25I. 
Mars's helmet is supported by a winged Pegasus, that of Minerva's by an owl. The image on the Cancelleria relief could therefore be considered a reflection of a statue of Mars set up in the Forum Augustum by Domitian, of which the head of the Capitoline Mars survives with its plume adorned with pegasi and sphinx. This divine head, perhaps found before I 520 in the Forum Augustum, was joined in the later I53Os to the imperial torso recovered from the Forum of Nerva.

Since the I520s it had become 'standard practice' to restore better-quality finds of ancient sculpture according to the principle that an antique work was only held to be of value if it was 'complete'. ${ }^{2}$ But the parts did not have to be from the same original work. There were frequent attempts in the Renaissance to complete fragmentary antique sculptures in order 'to round out an iconography that is understood to be already evident, though even in these cases there may be disagreement as to what is evident'. ${ }^{73}$ Here too torso and head originated from different places. But there is no firm evidence that de Massimi found either of them. The sum he paid according to Aldrovandi would have been very high for a torso, even if as Müller suggests he already possessed the head, but it might have been more realistic for a nearly complete restored statue ideally suited as the visual focus of his new palace courtyard, particularly if the labour of the restorers was taken into account. By 1540 it was in position there, but without arms; within a few years, the restoration of the statue had been completed with the addition of the arms and the crest of the helmet. It would not have been altogether surprising if, after his death, his sons had claimed, even despite Aldrovandi's statement, that the whole statue had been found by him. Sallustio, misled by this false claim and confused by the drawing of the no-longer-visible exedra of the Forum Augustum, made sense of these reports by producing a fanciful reconstruction of the Forum of Nerva on which he stated that the whole statue had been found by de Massimi in its northern exedra. In short, this statue, which was reconstituted from a Flavian imperial torso, an independent Flavian divine head, and sixteenth-century limbs, provides no evidence that the archetype of the Algiers Relief originated in the Temple of Mars Ultor.

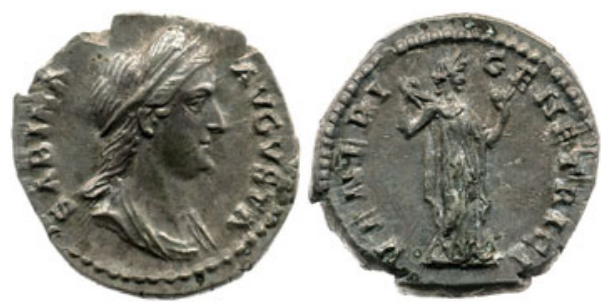

FIG. 22. Silver denarius of Vibia Sabina, A.D. I28-I36 (RIC II Hadrian 396). British Museum, inv. no. I867, ОIOI.I685 (BMC 944).

The connection between the relief and the Temple of Mars Ultor is even thinner for the other two statues of the relief. Zanker's suggestion that the female figure is Venus Genetrix has become accepted as fact. ${ }^{74}$ However, it is entirely different from the Venus Genetrix type, which is well attested by surviving statues and coin representations. The distinctive

72 Haskell and Penny I98I: I03; Montagu I989: I 5 I.

73 Barkan I999: I78. For instance, among the antique sculptures in the Casa de Pilatos in Seville, collected and restored between I559 and I57I, the statue of 'Ceres Frugifera' consists of an antique ideal head added in the sixteenth century to a portrait type body, while that of Pallas has a sixteenth-century restored head added to an antique torso. See Trunk 2003: 259-6I, figs 3-5.

74 The identification of the female figure in the Algiers Relief as Venus Genetrix is given by Zanker I988: I97, caption to fig. I5I, although in the main text he distances himself from this interpretation, attributing the 
characteristics of that statue type are recognized from a coin of Hadrian's empress Vibia Sabina with the legend VENERI GENETRICI, which shows the goddess wearing a light, see-through chiton and holding out in her left hand the apple won by the Judgement of Paris (Fig. 22). ${ }^{75}$ The reference point on the denarius of Sabina is the original statue dedicated by Caesar in the Temple of Venus Genetrix in 46 B.C. and attributed by Pliny to the Greek artist Arcesilaus. ${ }^{76}$ Ennio Visconti thus identified Arcesilaus' statue of Venus Genetrix on the basis of this coin and a sculptural replica in the Museo Pio-Clementino in the Vatican, and this identification is confirmed by several further sculptural replicas. ${ }^{77}$ The best examples, in the Capitoline Museums and the "Aphrodite of Fréjus' in the Louvre (Fig. 23), clearly show these features of the dress and the gestures of both the left hand reaching out with (originally) the apple and the right hand lifting the folds of the loose-fitting chiton to reveal her left breast. By contrast, the female figure on the Algiers Relief (Fig. 3) holds her right hand on her right hip, has no extended left hand or apple, and, although her left shoulder is bared, her left breast is covered by her garment, which appears to be of rather thicker cloth than the see-through chiton of Callimachus' and Arcesilaus' statues. She is more of a matronly figure, still with an attractive, youthful face, but fully clothed, and is now accompanied by her child, Cupid, who reaches up to her from below with his diminutive sword in a manner not unlike the family groups on the Ara Pacis, while his mother looks resolutely forward. This female figure on the relief, while clearly identifiable as Venus, is not easily recognized as Venus Genetrix.

The attribution of the statuary group of the relief to the Mars Ultor temple is most questionable because of the inclusion of the Caesar statue. One might expect that a temple vowed to avenge Caesar's murder would have included him in its iconography. But there is no evidence that the Divus Julius was present. His statue is absent from both Ovid's account of the temple and the detailed representation of a pediment on a relief in the Villa Medici which has been identified with the temple (Fig. 24). ${ }^{78}$ As is well-known, the temple was dedicated forty years after the vow, and, in the meantime, the revenge motive had become transformed into an avenging not of Caesar, but of the Parthians' capture of Roman standards in 53 B.C., recovered in 20 B.C.

In fact, coins struck in I9/I 8 B.C. (Fig. 25), when Dio reports a decree of the Senate to build a temple of Mars Ultor on the Capitoline to house the standards, show a very different Mars Ultor type. ${ }^{79}$ The image of Mars the Avenger envisaged here is helmeted, but beardless, following a late Republican type; ${ }^{80}$ otherwise, he is lightly armed, wholly different from the Mars on the relief and the gem and closer to the hip-mantle attitude of the temple pediment. In particular, he carries a military standard and eagle, the meaning of which another coin type from the same year makes plain by the label signis

statue to 'a Classical Aphrodite type ... [perhaps] even a reused Greek original'. Nonetheless, it is repeated, e.g. by Rives I995: 52, that the relief represents Mars Ultor and Venus Genetrix.

75 RIC II Hadrian 396: Sabina denarius, A.D. I28-I36. Cf. BMC Hadrian I903.

76 Pliny, $H N$ 35.45.I 5 5-6. According to Pliny, Arcesilaus' representation of Venus was derived from a statue of Aphrodite by the sculptor Callimachus, which was dressed in a light, clinging chiton, lowered to reveal her left breast.

77 Visconti I790: 8, pl. VIII, referring at n. (e) to Anton Maria Zanetti the Elder and Anton Maria Zanetti the Younger, Raccolta delle antiche statue, Greche e Romane ... (Venice: G. B. Albrizzi, I740-3), II, I4, pl. xiv, who were already aware of the coin of Sabina; Waldstein I887: Io mistakenly calls these authors 'the Zanetti brothers', although in fact they were cousins.

78 Cagiano de Azevedo I95 I: 56-64, no. 3. The identification of this pediment with the Temple of Mars Ultor by, among others, Zanker I968 and I988 is rejected by Torelli I982: 77 on the grounds that the central figure differs from the supposed 'Mars Ultor' in the Capitoline Mars and the Mars of the Algiers Relief.

79 RIC I $\mathrm{I}^{2}$ Augustus 68-74: denarius of Augustus, with shrine of Mars Ultor on reverse.

80 Crawford I974: $R R C$ 3 I9/I: denarius of Q. Minucius Thermus, with helmeted head of Mars Ultor on obverse and two warriors fighting over a fallen comrade on reverse. 


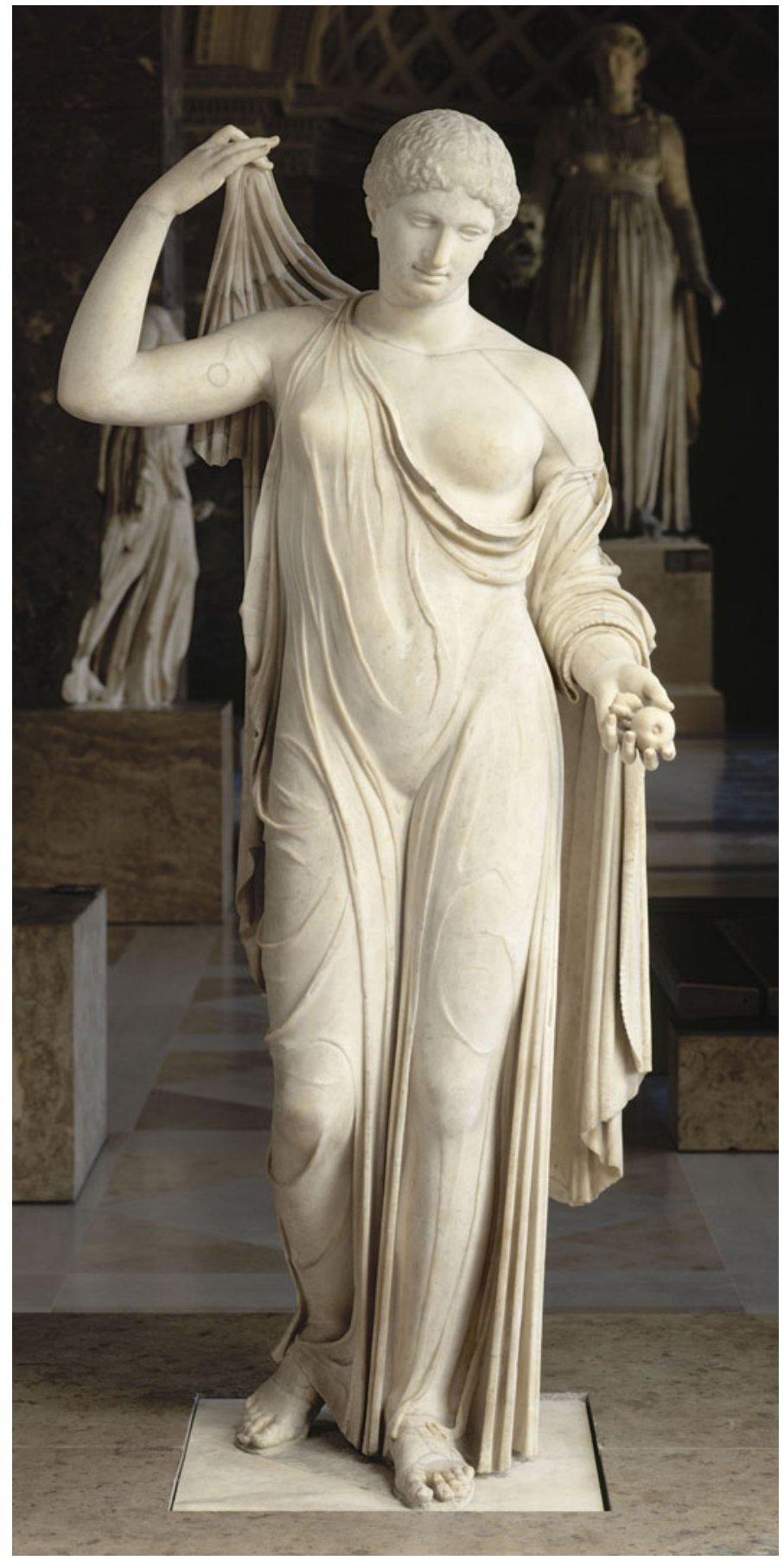

FIG. 23. Marble statue of the Aphrodite of Fréjus, Paris, Musée du Louvre Ma 525. (Photo: () Dist. RMN-Grand Palais / Etienne Revault) 


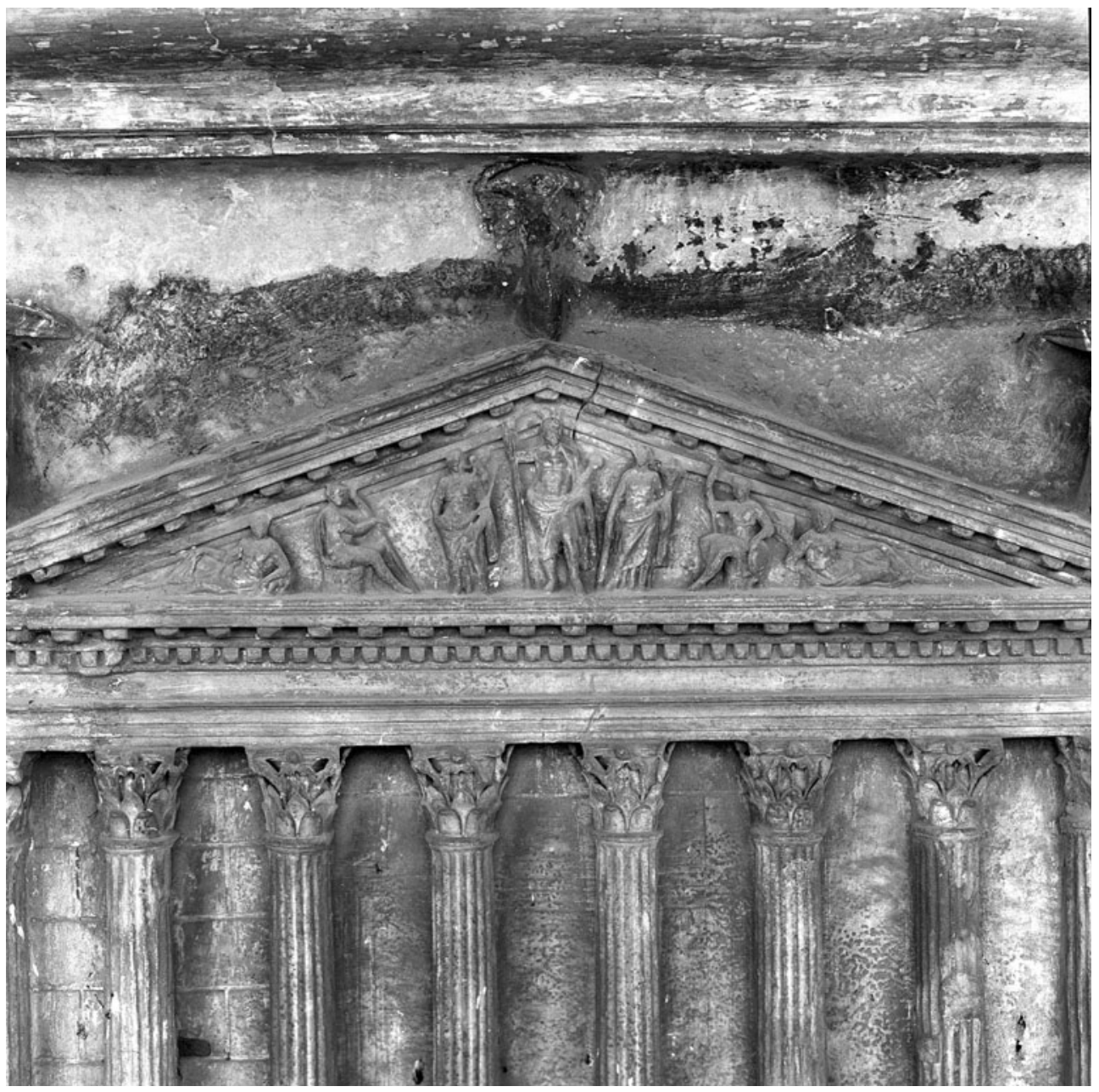

FIG. 24. Relief from the Villa Medici, Rome. (Photo: B. Malter I3I3-02)

receptis. ${ }^{81}$ The round temple shown on the coin appears never to have been built, perhaps because it was rejected by Augustus; ${ }^{82}$ but the standards would be set up in the cella of the eventual temple of Mars Ultor, dedicated in 2 B.C.
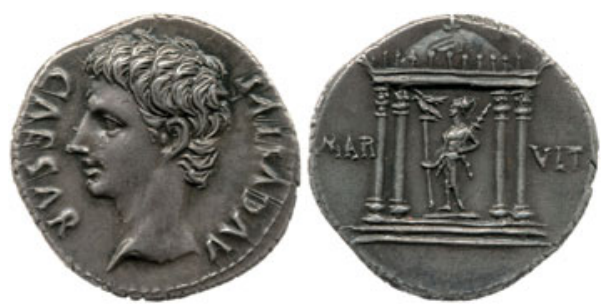

FIG. 25. Denarius of Augustus, showing round temple of Mars Ultor (RIC I² 69b). British Museum, inv. no. R.6090.

81 RIC I $\mathrm{I}^{2}$ Augustus $39 \mathrm{~b}$ and $4 \mathrm{I}$ : denarius of Augustus, with Mars holding standards on reverse.

82 As proposed by Rich 1998 . 
Archaeological analysis of the apse of the Temple of Mars Ultor undertaken since Zanker set out his ideas in his Forum Augustum and published after their reiteration in his Power of Images supports this numismatic view of the cult image of the Temple of Mars Ultor. The stepped podium at the back of the apse (Fig. 26) was not strong enough as a foundation for statuary, and Joseph Ganzert rules out not only the display here of the three-figure group on the Algiers Relief, but any statuary display at all. ${ }^{83}$ Ovid's account in the Fasti also makes no mention of any cult statues in the temple. ${ }^{84}$ More likely, Ganzert suggests, was simply a military standard and an iconic spear, enough to suggest allegorically the presence of Mars. Revetment in rare Egyptian alabaster or 'onyx' highlighted the installation.

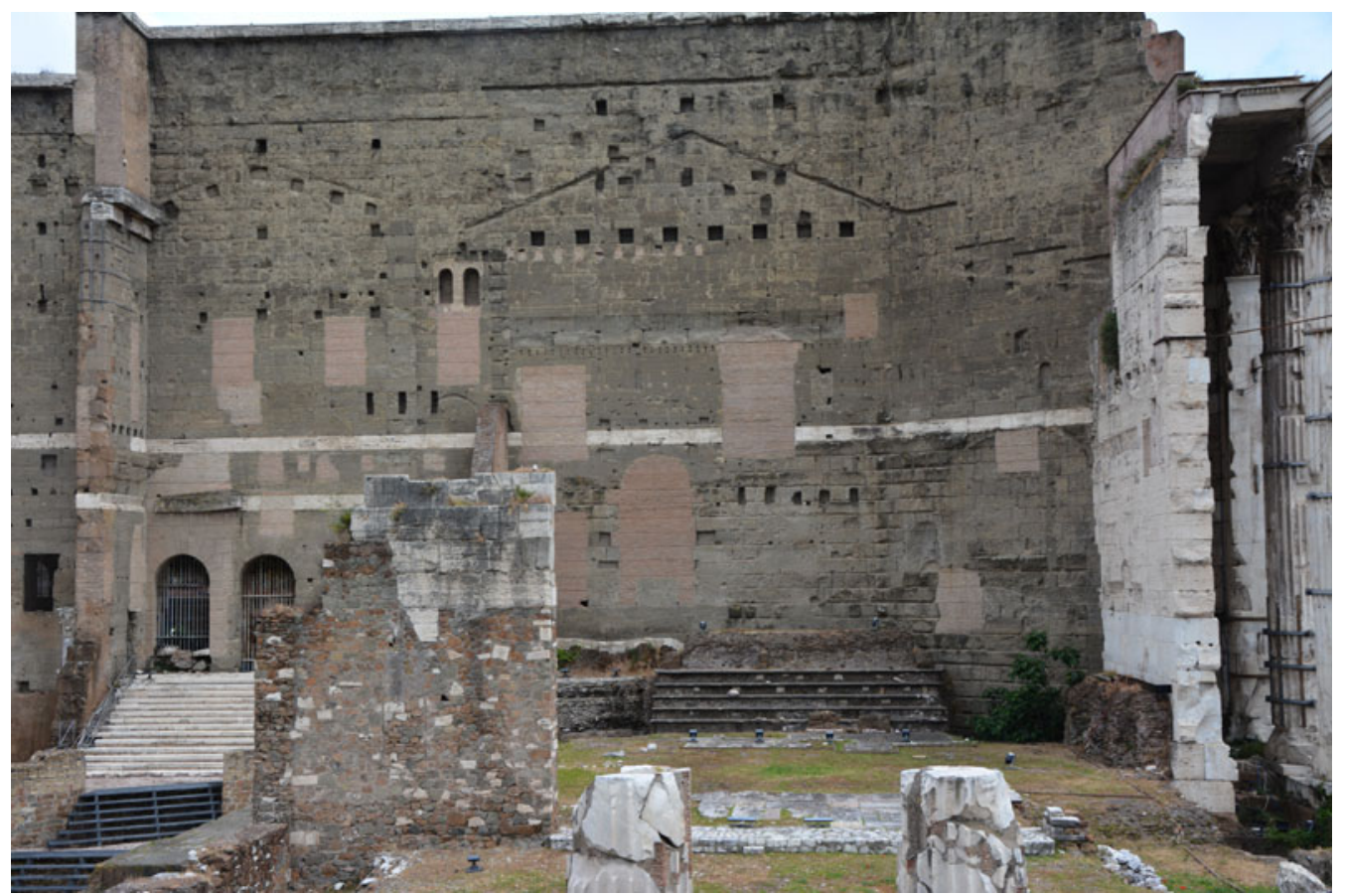

FIG. 26. Temple of Mars Ultor, Rome: remains of the cella with stepped podium at back of apse. (Photo: author)

Certainly, it is known from Ovid's Tristia that there was an image of Mars and Venus inside the temple cella. ${ }^{85}$ Yet it cannot have looked like the two statues on the Algiers Relief. First, there was no Caesar at the side. Second, Ovid is explicit that Venus was 'Vltori iuncta', 'wrapped around Mars', in Peter Green's translation. ${ }^{86}$ This implicit sexual proximity, not just standing beside one another limply as most commentators take the words, is explicit later in the poem in the phrase 'Martem Veneremque ligatos'. ${ }^{87}$ This could hardly indicate the Algiers group, where there is minimal contact between the gods, but suits much better other known statuary compositions of the pair,

83 Ganzert I996: 136-44 and 290-2 with fig. 37 and pls 33-5.

84 Ov., Fast. 5.553-68. As noted by Kraus I979: 240.

85 Ov., Trist. 2.I.295-6.

86 Green 2005: 33.

87 Ov., Trist. 2.I.377. Contrast, e.g., André 1987: 49 ('auprès du dieu Vengeur'). For the mischievous way in which Ovid both advances a lascivious reading of this sculpture, which complicated the intended selective 
like the over-life-size statue from Ostia in the Museo delle Terme, where the divine lovers are caught in an embrace (Fig. 27). This group, like two other replicas, in the Capitoline Museums and the Louvre, ${ }^{88}$ is a later work, created in the Antonine period when the group had become limited to the private sphere as a statement of romantic love in a more selective and personalized engagement with Greek myth: the gods' heads were refashioned as portraits of private couples, or, in one case, possibly as the imperial couple Marcus Aurelius and Faustina, on whose coins an image of the statue is depicted. ${ }^{89}$ However, as Zanker himself has argued, it appears to have been based on an Augustan prototype, and this is confirmed by Rachel Kousser, who shows that such combining of classical models to express the moral authority of the Augustan régime was already widespread before A.D. 70.90 That the original of this composition existed in the Temple of Mars Ultor is shown by a small and unprepossessing fragment of a statue group in Parian marble from the Forum Augustum (Fig. 28). ${ }^{91}$ On the front is preserved the leftward turn of Mars's neck and the top of the balteus strap across his torso; on the rear, Venus' left hand behind her lover's neck. The dimensions and proportions of the fragment are extremely close to those of the copy in the Terme Museum. Although Zanker persists with Gsell's identification of the Algiers Relief as the cult image of the temple and suggests that the original of Venus embracing Mars was an additional sculpture in one of the intercolumniations of the cella, his argument is forced, since only the latter statue is clearly attested in ancient literary descriptions of the temple, while there are no free-standing copies of the former group attested and no space for it in the temple apse where Zanker would have it located.

\section{THE STATUES OF AGRIPPA'S PANTHEON AND EARLY AUGUSTAN IDEOLOGY}

Furtwängler argued reasonably that the widespread replication of the Mars Ultor statue type in the West indicates that it must have been derived from an original in a high-profile cult building in Rome. But, as has been demonstrated, it cannot have stood in the Temple of Mars Ultor. Given the combination of deities on the Algiers Relief, the possibility that the original statue stood in Agrippa's Pantheon, another prominent building of Augustan ideology, is worth considering alongside the place of the group within the development of Augustan iconography.

The image of Mars on the Marlborough Gem (Fig. 5), bearded, armed and leaning on his shield, was no invention of the Augustan period, but, like the beardless type, had already been adopted from late Classical prototypes. In the centre of a terracotta pediment from the mid-second century B.C., found in the Via di S. Gregorio and now in the Capitoline Museums, is an armed figure (Fig. 29) strikingly similar in pose and attributes to that on the gem. ${ }^{92}$ It is derived from precursors in the Greek world, as a third-century B.C. metope relief from the theatre at Thasos (Fig. 30) makes clear. ${ }^{93}$ It

reading as a statement of the intimate bond between Rome's divine ancestors, but also appears to reject it, see Kousser 2007: 48-54.

88 Rome, Museo delle Terme Io8522 (from Ostia); Capitoline Museums inv. 652; Paris, Musée du Louvre Ma I009.

89 Kousser 2007: I06-Io. Coins of Faustina II: RIC II I680; BMC 999; Mikocki I995: I99-206.

90 Zanker 1988: 198; Kousser 2007: 48-54.

91 L'Orange I932; Zanker I968: I9.

92 Because of the figure's central position in the pediment, it has been suggested that the pediment found in $\mathrm{I} 878$ came not from a temple of Fortune, as generally believed because of the two female images of the goddess on either side, but from one of Mars situated perhaps in the Campus Martialis on the Caelian Hill or, more likely, at the Porta Capena, just below the church of S. Gregorio. For specific arguments, see Ferrea 2002: 6I-73.

93 Istanbul, Archaeological Museum. Salviat I960: 307, fig. 4. 


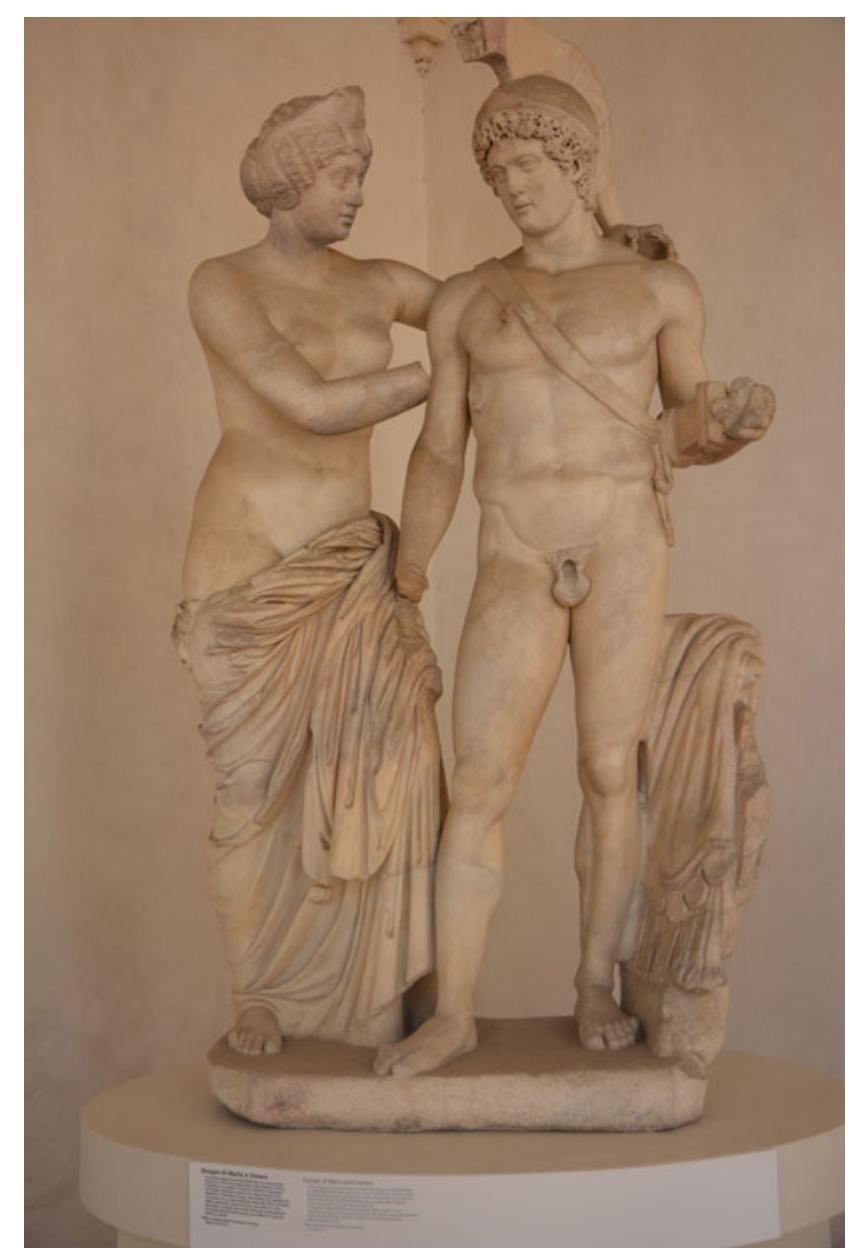

FIG. 27. Statue group of Mars and Venus. Rome, Museo delle Terme I08522. (Photo: author)

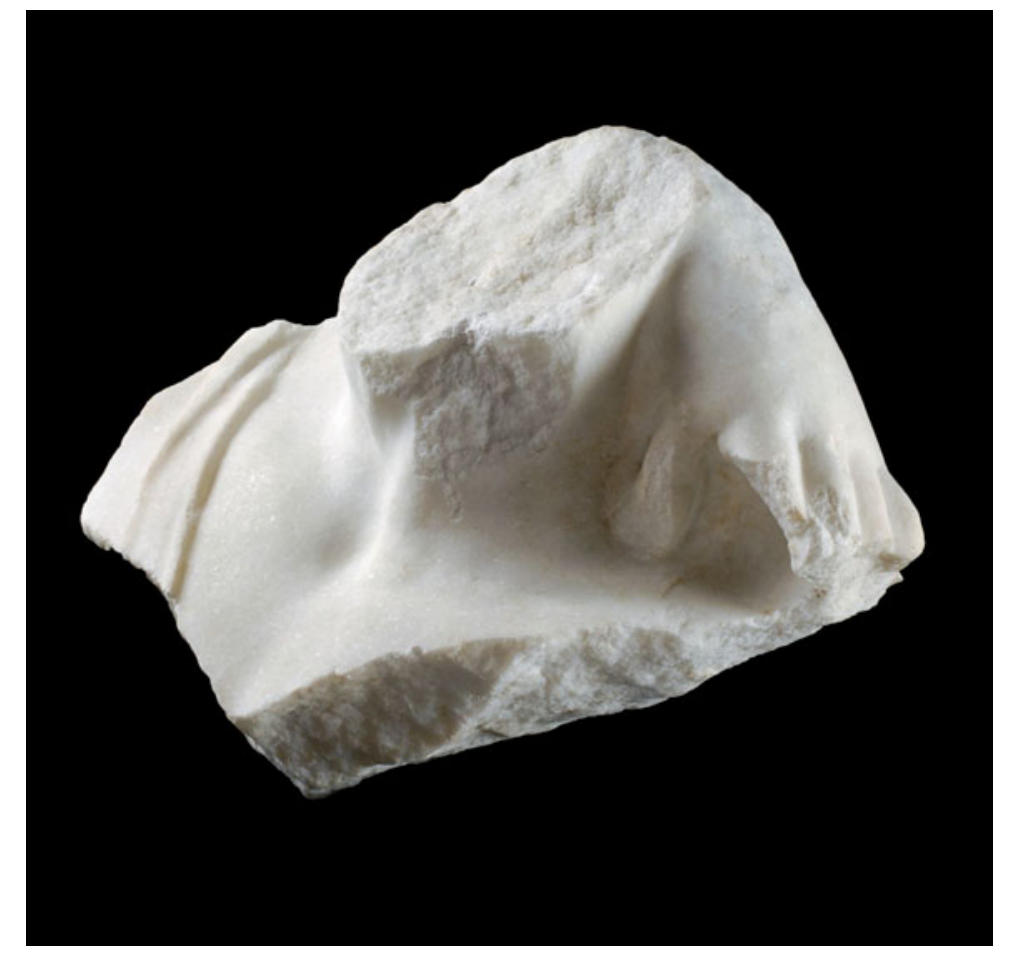

㽦

FIG. 28. Fragment of marble sculpture from the Forum Augustum. Rome, Sovrintendenza Capitolina ai Beni Culturali, Mercati di Traiano - Museo dei Fori Imperiali 2563. (Photo: Stefano Castellani) 


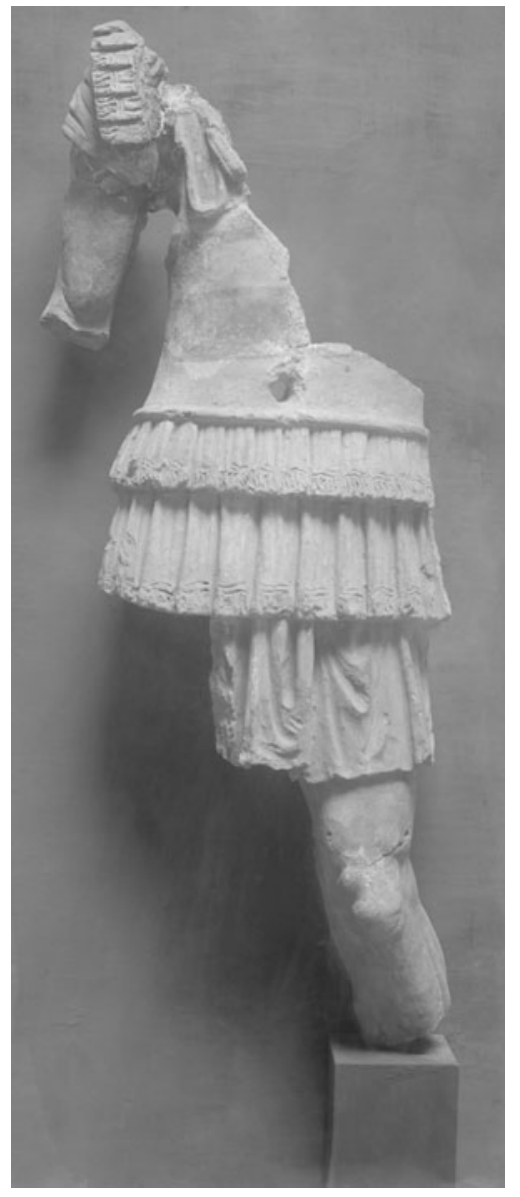

FIG. 29. Fragment of statue of Mars from the Via di S. Gregorio, Rome. Rome, Capitoline Museums. (Photo: German Archaeological Institute Rome, neg. no. 37.795)

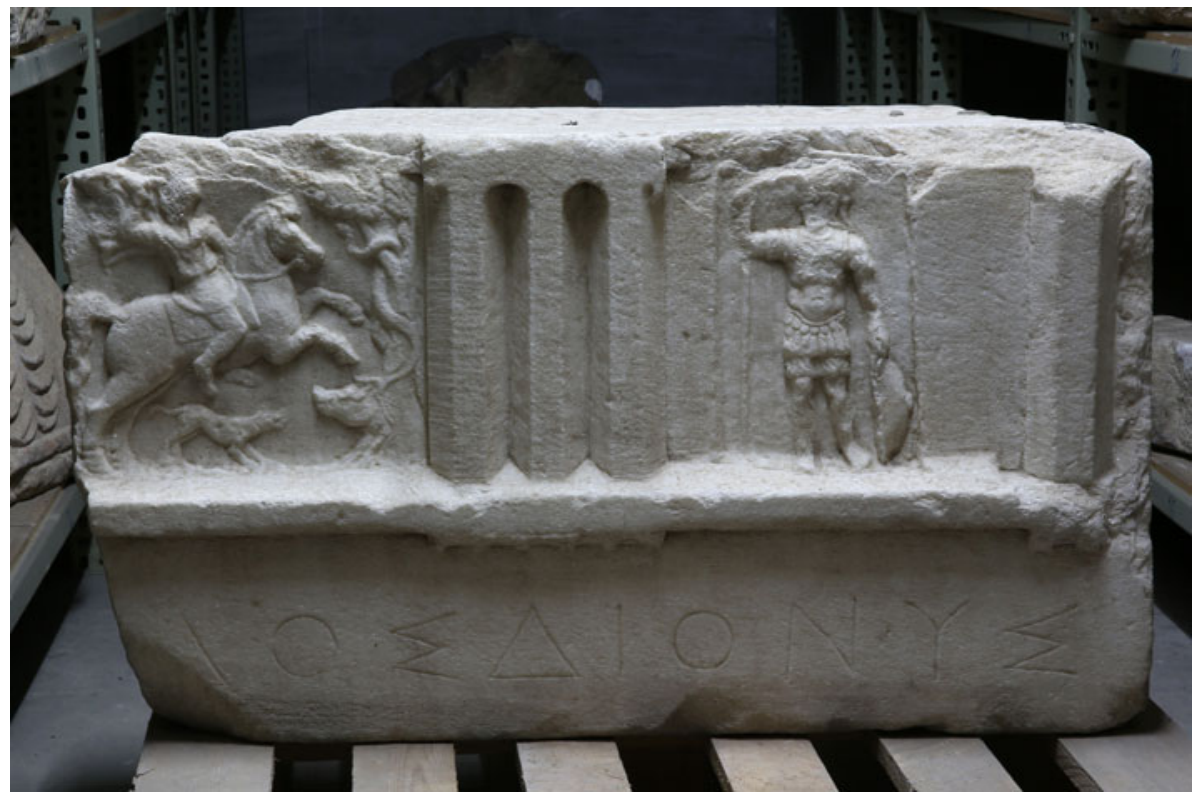

FIG. 30. Fragment of Doric frieze from the theatre at Thasos (Mendel, cat. no. I087). Istanbul, Archaeological Museum, inv. 382. (Photo courtesy of Zeynep Kiziltan, Director of the Istanbul Archaeological Museum)

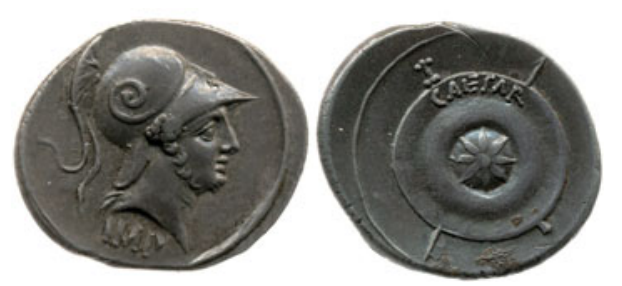

FIG. 3I. Denarius of Octavian, uncertain mint (Brundisium?) (BMC 644). British Museum, inv. no. I $84 \mathrm{I}, 0916.5$. 
was to this earlier image of Mars that Octavian appealed early in his return to Italy after Actium. A bearded head of the god occurs among the first obverse types he issued (Fig. $3 \mathrm{I}$ ), probably at Brundisium, before the mint at Rome was reopened, to convert his new wealth from the East into money for his troops. ${ }^{94}$ It falls within the second set of the series, issued in the name of 'Imperator Caesar', with that title split between obverse and reverse. Its symbolic iconography is so allusive that discussions of Augustan coinage have largely overlooked it. ${ }^{95}$ On the obverse, the letters IMP appear below the helmeted and bearded head of Mars; the reverse shows a shield laid over a sword and spear with the word CAESAR written on the outer rim of the shield and an eight-pointed star at its centre. Although not explicitly labelled 'Ultor', the weaponry associates Mars with offence, and the shield is tied to the avenging of the Divus Julius both by the central star and by the explicit label 'Caesar', transferred by the manipulation of numismatic space from titular obverse to iconic reverse. There is no question here, of course, of a Mars avenging the Parthians, a venture then far from imagining. Now, just a few years after Actium, Octavian still had revenge on the killers of Julius Caesar very much in his mind.

It is tempting to argue that these two senses of the avenging Mars were easily fused in contemporary perceptions of the Temple of Mars Ultor. ${ }^{96}$ But such a view is mistaken. In the first place, it ignores the satirical, almost mischievous sense of Ovid's allusion in the Fasti to the ideological inconsistency; the phrase 'nec satis est ...' seems to say: 'if one mission of revenge was not enough, another one was concocted'. 97 Second, such an argument fails to acknowledge the shift in iconography from Octavian's paternal avenger, presented here in the early 20 s as helmeted and armed with spear, sword and shield, shown in full on the Algiers Relief, to the heroic, semi-nude figure after 20 B.C. associated on the coins of I9/I 8 B.C. and on the temple pediment with the avenging of the Parthian capture of the standards; likewise, in the statue group in the temple cella Mars was not fully armed, but semi-nude, a costume which encouraged Ovid's sexual reading in the Tristia. Finally, the fusion in perception of these two avengers came about only after the dedication of the forum in 2 в.C. The helmeted and fully armed Mars appeared within the forum precinct not as an Augustan cult statue of the temple, but only as a votive statue outside, for which the head of the 'Capitoline Mars' and the figure of the Cancelleria relief offer potential evidence. Such a statue possibly originally stood in the southern exedra of the Forum Augustum, but apparently dated only to the Flavian period. It was this fully armed Mars of the forum, not the semi-clad one of the temple cella or pediment, which became employed and labelled in subsequent iconography as Mars the Avenger. ${ }^{98}$

The Algiers Relief (Fig. 3) reflects a situation when celebration of the recovered standards was a long way off. Mars is in the same rôle defined on later gems and coins as 'the Avenger'. Such revenge, however, was on behalf of the murdered Caesar, as the coins of 29-27 B.C. make plain. That this was the statue group installed in the Pantheon by Agrippa would fit other details recorded of the building. Pliny records that the statue of Venus had in each ear half of the single pearl left from Cleopatra's ear-rings after she

\footnotetext{
94 AR denarius of Octavian, uncertain mint (Brundisium?). Reverse legend: I • CAESAR. RIC $\mathrm{I}^{2}$ Augustus 274; BMC 644. Three specimens.

95 RIC I ${ }^{2}$ Augustus 274, with pl. 5.

96 As was argued, for example, by Trevor Mahy in a paper, 'Reading Caesar back in: the Temple of Mars Ultor and the Forum of Augustus', presented at the American Philological Association Annual Meeting at San Antonio, Texas, in January $201 \mathrm{I}$.

97 Ov., Fast. $5 \cdot 579$.

98 This bearded Mars reappears in the second half of the first century A.D., against the prevailing beardless version of the Julio-Claudian period which followed Augustus' Temple of Mars Ultor. It occurs on civil war issues in Germany in A.D. 68; in imperial coinage it is first seen again on a bronze issued in the name of Britannicus, ostensibly in the final years of Claudius' reign, but in fact probably minted only under Titus: BMC 226 (Claudius) and 306 (Titus).
} 
had swallowed its pair in a bet with her lover Antony. ${ }^{99}$ The presence of this emblem of the bond between the Egyptian queen and the Roman triumvir demonstrated how far the building's decoration, like other projects of the early 20 such as the Mausoleum, was still bound up with the ideology of Actium and Octavian's response to Antony. ${ }^{100}$ The pearl remained symbolic testimony to Octavian's victory over his rival as Caesar's heir. This meaning became plainer still when Agrippa added the statue of Caesar to the pair of Mars and Venus. The evidence of Agrippa's modification is present in the relief: as Kraus noticed, the figures do not seem to belong to a fully unified group; yet this need not mean, as he supposed, that they did not belong to one group at all, but only that they had not been conceived at the same time. That would fit Dio's report, which not only puts Venus and Mars together, but presents the decision to put the Deified Julius in the interior without Augustus as a secondary one. Venus and Mars face each other, but the third figure is set slightly apart, and Mars seems to turn his back on him, as if Caesar was not originally intended as part of that group. Yet the figure is integrated with the images of the two gods through the conspicuous gesture of his right arm, which seems to try to touch Mars's shield. These details suggest that the erection of the work took place in two stages. First, the pair of Mars and Venus was composed as a separate group, facing each other. Then, after the addition of the Divine Julius to the group, a virtue could be made of this necessity. Rather than seeming to turn his back on Caesar, Mars was in fact standing in a protective pose: in other words, as Caesar's avenger. The way in which Caesar moves his right arm forward to touch the shield subtly communicates this link between them.

The corona civica on the shield (Fig. 3 ) is usually taken as suggesting a connection with Augustus, the most famous recipient of that honour. However, Augustus' association with this adornment was undoubtedly motivated by its having previously been awarded to Caesar twice, first after the siege of Mytilene in 80 B.C. by the Roman proconsul of Asia, M. Minucius Thermus, for having saved the life of a Roman citizen, and again in 44 B.C. on the Rostra as saviour of the whole citizen body. ${ }^{101}$ An echo of the statue on the Rostra survives in the Thasos head of Caesar, a sculpture close in style only to the posthumous Chiaramonti head. ${ }^{102}$ The original bronze statuary of the Deified Caesar may also have shown him wearing the more notable golden crown awarded to him, as has been inferred from the strange indentation and crease in the hair at the back of the marble copy from Tusculum, now in Turin. ${ }^{103}$ The oak leaf crown on the shield of the statue of Mars - we may now call him Mars the Avenger, to follow the label of the gems and the coins - makes the same statement as the name 'Caesar' on the coin of 29-27 B.C., connecting the god of war with the Deified Julius. The statue of Augustus originally planned here by Agrippa would have shown the Princeps' link to the Julian theme prevalent in the early 20 B.C., connected by the common honour of the corona civica.

Yet what of the star which was a symbol not only of Caesar's divine status and right to stand with the other two gods in the temple's pride of place, but also of the murder preceding that deification which Caesar Augustus was committed to avenge? It appears on that coin in the central boss of the shield marked with Caesar's name (Fig. 3I). Gsell's observation of the Algiers Relief suggested that a star had originally been

\footnotetext{
99 Pliny, HN 36.58.II9-22; Kleiner 2009: I60-2, who also interestingly assumes that Caesar's statue was near those of Mars and Venus, though she does not go so far as to make them a single group.

100 On the Mausoleum, see Kraft 1967. The inclusion in the interior decoration of Caryatids, interpreted at this time by Vitruvius (I.4.8-5.I I) as an example of female slavery, could similarly be read in terms of the punishment of Cleopatra.

101 Suet., Div. Jul. 2; Cass. Dio 44.4.5.

102 Thasos, Archaeological Museum; Koortbojian 20I3: I20, pl. V.36.

103 Koortbojian 2013: I23.
} 
attached there too. Should one assume that it was part of the original statue? The star appears for the first time in 38 B.C., on coins of Agrippa no less, beside a bust of Octavian with a legend announcing him as son of the Deified Julius. It did so as part of a group of coins which tied together Octavian and the Divus Julius as almost interchangeable. ${ }^{104}$ Two years later it appeared on the pediment of the projected Temple of Divus Julius. ${ }^{105}$ But, as we have seen, it does not occur on surviving posthumous statuary of Caesar. It does not seem to reappear in the coinage until I9/I 8 B.C. when it was used on its own to give theological backing to the new Golden Age imagery of the coming Secular Games of I7 B.C. ${ }^{106}$ The star also appears on the head of Caesar on the Sanquinius coin (Fig. 7). This coin has been connected with the actual Secular Games of I7 B.C. when the comet of Caesar was allegedly seen again. ${ }^{107}$ What statue did the Sanquinius coin celebrate? It would have been fifteen years too early for any putative statue of Divus Julius in the Temple of Mars Ultor.

The addition of the statue to the pair of Mars and Venus in the Pantheon would fit this well. The coin of L. Lentulus (Fig. 8) may show the addition envisaged. On the reverse are two figures: one in a 'hip-mantle' costume, on the left, being crowned by another, on the right, who, holding a shield labelled 'CV' (Clipeus Virtutis), is identifiable with Augustus. ${ }^{108}$ As the two figures stand on a single long base, the composition is clearly recognizable as the depiction of a statuary group. Mattingly located it in the Temple of Mars Ultor; Newby in the Pantheon. ${ }^{109}$ The group resembles the parastēma sculpture groups of Antigonid and Seleucid ensembles, a metaphorical visualization of a civic honour in which the personification of a locality crowns a ruler. ${ }^{110}$ The coin is generally dated to I 2 B.C., and both Mattingly and Newby followed the earlier identification of the 'hip-mantle' figure as Agrippa. ${ }^{111}$ There is, however, no parallel for Agrippa in this costume, let alone with a star, and others have recognized that both attributes identify the figure more easily as the Deified Caesar. ${ }^{112}$ Yet it has proven hard to explain why coins showing this statue group should have been minted in I 2 B.C. ${ }^{113}$ Donié suggests a hypothetical connection with Gaius and Lucius Caesar, the sons of Agrippa and potential heirs to their grandfather Augustus. ${ }^{114}$ Koortbojian connects the coin with Dio's account of the comet appearing around the time of Agrippa's death, and argues that as pontifex maximus Augustus then had supreme power over religious matters. ${ }^{115}$ On this interpretation, the otherwise undated Lentulus would be one of the tresviri monetales of I2 B.C. However, an earlier date is possible. ${ }^{116} \mathrm{~A}$ particular problem with the traditional date is that Lentulus' office on the coin is not tresvir, but flamen

\footnotetext{
104 Crawford I974: RRC 534/I-3 (denarius of M. Agrippa, 38 B.C., with the same reverse type and three different obverse types). Interestingly, there is a similar interchangeability on Piso's coins of I7 B.C. where the reverse shows Numa, father of Roman religion; see Kraft I952-3: 74-84.

105 Octavian bust: Crawford I974: $R R C$ 534/I (aureus of 38 B.C.); temple of Divus Julius: Crawford I974: RRC $540 / 2$ (denarius of 36 B.C., southern or central Italian mint).

106 RIC I $\mathrm{I}^{2}$ Augustus $37 \mathrm{a}-\mathrm{b}=$ BMC 326 (denarius of Augustus, Caesaraugusta mint, c. I9/I 8 в.C.).

107 Obsequens Liber de prodigiis 68; Sanquinius coin: RIC I ${ }^{2}$ Augustus 337-40 (denarius of Augustus, Rome mint, tresvir monetalis M. Sanquinius).

108 RIC I ${ }^{2}$ Augustus 4I $5=$ BMC I 24 .

109 Mattingly I923: cviii; Newby I938: 52.

110 For examples, see Kruse I992; Ma 2013: 47-8.

111 Mattingly I923: cviii; Newby I938: 52; Fraschetti I990: 310-I8; Roddaz I984: 600-I.

112 Babelon I963: I, 43 I (incongruously identified as dedication of Julius Caesar in the Temple of Mars Ultor, yet dated to I7 B.C., and crowned by Lentulus himself in priestly robes); Grueber I9IO: II, IO2, no. 4674, n. I ('the bronze statue of Caesar, which he had erected in his honour in the temple of Venus'); Weinstock I97I: I02 and 379 (with a date of I7 B.C.); Fittschen I976: I 86-7; Fullerton I98 5: 479; Zanker 2009: 299.

113 Zanker 2009: 299.

114 Donié I996: 8.

115 Cass. Dio 54.29.7-8; Koortbojian 20I3: I44-5.

116 Burnett I977: 48-9.
} 
martialis. On the other hand, the period between 27 and I9 B.C. would offer a more appropriate numismatic context. If the coin had been minted after the series issued by Octavian in his own name in the wake of Actium, but before his revival of the Republican system of tresviri, it would explain why Lentulus is indicated as holding not that rôle, but the office of flamen martialis. As Grueber long ago observed, if this was L. Cornelius L.f. Lentulus, the son of L. Cornelius Lentulus Niger who had also been flamen martialis, ${ }^{117}$ as is usually believed, the coins could scarcely have been struck in his name as late as 17 , let alone I 2 B.C., when he would have been exceptionally old for that office. ${ }^{118}$ Assuming that the date must be correct, Grueber suggests that this was the son of the younger Lentulus; a date around 25 B.C., however, would fit the traditional identification very well, for an obsequious gesture of allegiance to Augustus by a former supporter of Antony. ${ }^{119}$

On this interpretation the Lentulus coin would show a proposed design for the statuary group of Agrippa's Pantheon, consistent with Dio's account that Agrippa had originally wanted to include both Caesar and Augustus in the interior of the building. It shows the direction of Augustan ideology in the 20s B.C., the early years after the Settlement of 27 B.C., based around the idea of Augustus as avenger of Julius Caesar. It is possible to identify the inspiration for this ambitious statue group. In a building at Antioch the territorially more limited meaning of the parastēma type in the earlier Hellenistic examples had been taken a stage further, with the Goddess Tyche shown as crowning Gē (Earth), who in turn was represented as crowning Alexander. ${ }^{120}$ The statue group envisaged on the Lentulus coin seems intended to show Caesar's divinization validated by Augustus, just as at Antioch Alexander's conquest of the earth was confirmed by Fortune, with a similar use of Nike imagery. The resonances of Alexander for Caesar during his lifetime made this a natural point of reference. ${ }^{121}$

This also helps to understand the rest of the statuary of Agrippa's Pantheon. Although the building at Antioch is identified in the late antique description as a 'temple of Tyche', there are grounds for believing that it had been established as a Pantheon by Antiochus IV Epiphanes. As the writer comments, 'the name of the gods had been hidden because of Tyche'; yet the original meaning was still evident in the statues of the twelve gods that surrounded the threefold parastema group of Tyche, Earth and Alexander. ${ }^{122}$ The celestial interests of Antiochus were evident in his great procession of I66-5 B.C. at Daphne, where the divine images were 'followed by icons of Night and Day, of Earth and Heaven, and of East and South'. ${ }^{123}$ The building at Antioch was very likely the

\footnotetext{
117 Cic., Phil. 3.ro. A former friend of Antony, who appointed him to a province, he defended Scaurus in 54 B.C. and prosecuted Gabinius around the same time.

118 Grueber I9 I0: 2, I02, no. 4674, with n. I ('usually identified as L. Cornelius L.f. Lentulus, who was flamen martialis, and the son of L. Cornelius Lentulus Niger, who before him had filled the same office. The younger Lentulus defended M. Scaurus in 54 B.c. when accused of extortion, and himself accused A. Gabinius of high treason about the same time. He was a friend of Antony, by whom he was appointed to a province, but made no use of the office (Cicero, Philipp., iii.ro). If the above coins were struck by this member of the Cornelia gens they could not have been issued so late as 6 B.C., as proposed by Count de Salis, nor even in I7 B.C. as suggested by Babelon (n. I I 2 above). The moneyer was therefore probably a son of L. Cornelius L.f. Lentulus, and would be the third member of his family to hold the office of flamen martialis in succession, an appointment which must have preceded his magistracy at the mint. He was presumably related to the previous moneyer, Cossus Cornelius Lentulus, though of another branch of the family.').

119 Mommsen i 884: 80 leaves the date more open.

120 Ps.-Liban., Descriptions 25.6, attributed to 'Pseudo-Nikolaos'. For this identification of the building described by 'Pseudo-Nikolaos', which is usually located in Alexandria (McKenzie and Reyes 20I3), see Thomas forthcoming; Harder 201 2: 806 rejects the association of Callim., Aetia fr. I Io with a Pantheon at Alexandria.

121 For Caesar's emulation of Alexander, see Green I989.

122 Ps.-Liban., Descriptions 25.2, 5.

123 Polyb. 30.25.13, in Athen. 5, I94c-I95f.
} 
same as the 'Pantheon' at Antioch recently restored by Caesar himself. ${ }^{124}$ For a building with such an ensemble of divine statuary to be so called would fit what we know of the astrological meaning of the term. A hackneyed quotation attributed to Aristotle referred to 'the great visible god, which contains in truth sun and moon and the remaining pantheon of planets and fixed stars'. 125 The idea may have sprung from Aristotle's reference to a 'very ancient tradition' that 'these heavenly bodies are gods and that the divine pervades the whole of the natural world'. 126

With its main images similarly surrounded by statues of many other gods, Agrippa's project would fittingly have been called the 'Pantheum', emulating the monument at Antioch which Caesar had restored. The Alexandrian Philo considered the concept of a 'pantheon of planets' to be more representative of the beliefs of some 'Pythagoreans', including the Lucanian cosmographer Ocellus, so it would not be surprising to find its reflection in Italy. Elsewhere Philo himself uses the term to describe the kosmos as 'the $\pi \alpha \dot{\alpha} \theta \varepsilon 10 v$ of the sense-perceived order, the world which the mind discovers of the truly invisible order'. 127 So the name $\pi \alpha \dot{\alpha} \theta \varepsilon \varepsilon v v$ is easily explained by the building's planetary associations. Indeed, if the stories circulating in Dio's time that Agrippa wanted to name the building after Augustus are credible, it might already have been intended not just to include the statuary group of Caesar and Augustus, but to incorporate Augustus' new title in its name as not just 'Pantheum', but 'Pantheum Augustum'.128 But Augustus did not accede, because, importantly, these were not merely honorific adornments, but had the appearance of cult statues, and he resisted any idea of cult offered to him in Rome.

So Newby's old suggestion that the reverse image of the coins represents a statue in the Pantheon should be modified: the statue group shown on the coin of Lentulus was not actually erected, but represented a proposal of Agrippa which was rejected by Augustus. Instead, the statue of the Deified Caesar was erected on its own to the right of the group with Venus and Mars. As Dio writes, although formally a human statue, an andrias, it was not a portrait of the only too mortal Julius Caesar, but an image of 'the former Caesar', of him who had once been Caesar, but was now the Deified Julius, recognizable from his 'hip-mantle' costume. ${ }^{129}$ The parastēma motif was dropped, but would resurface towards the end of Augustus' life. On the Gemma Augustea, the enthroned emperor, is garlanded by Oikoumene, who with both her mural crown and her identification with the world combined in one figure the two goddesses that crowned the world-conquering Alexander of the Tychaion. ${ }^{130}$ The central group of Agrippa's Pantheon repeated the celestial reference of the Pantheon at Antioch with the planetary divinities Mars and Venus accompanied by the Deified Julius who represented the newest star of the firmament, as the star on his head proclaimed.

This combination of divinities also makes sense in relation to the purpose of Agrippa's Pantheon. Although scholars today argue that the complex was intended as a memorial to the Julii family or a celebration of the supposed apotheosis of Romulus-Quirinus on the site that suggested the 'quasi-divine status' of the emperor, these remain conjectures

\footnotetext{
124 Malalas, Chronicon 9, in Schenk von Stauffenberg I93 I: 216.I9-2I; Jeffreys et al. I986: I I4. Malalas also mentions the Pantheon at Antioch at the time of St Paul, around A.D. 40: ibid., in Schenk von Stauffenberg I93 I: 242. I I-I 2 and Jeffreys et al. I986: I28. For its identification with the Temple of Tyche described in Ps.-Liban., Descriptions 25, see Thomas forthcoming.

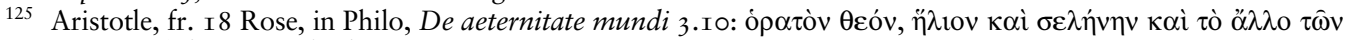

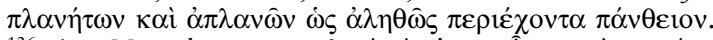

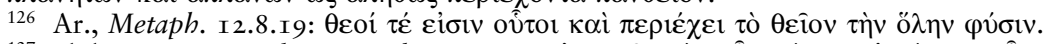

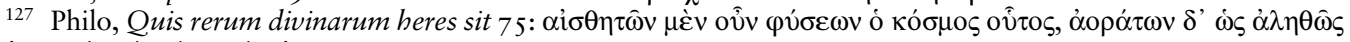

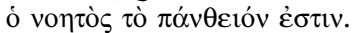

128 As suggested by Fishwick I992: 334-5.

129 For this interpretation of Dio's phrase, see Koortbojian 2013: I34.

130 Matheson I994: 94. For the Gemma Augustea, see Zanker I988: 232 and especially Pollini I993.
} 
unsupported by literary evidence. ${ }^{131}$ The only contemporary source that mentions the building, though it is nonetheless forgotten today, gives a clear, but very different indication of its function. Eighty years ago the architect and classicist Frank Granger (I 864-I936) demonstrated that Vitruvius himself mentioned the Pantheon in a passage which had been neglected because the manuscript reading was overwhelmingly dismissed in the early sixteenth century. ${ }^{132}$ At the start of the eighth chapter of his ninth book, Vitruvius lists several notable sundial devices designed by astronomers of the past. This is the text and translation based by Granger on the oldest surviving manuscript of Vitruvius, Harley MS 2767 now in the British Library, which he printed in his first Loeb edition of I934:

Hemicyclium excavatum ex quadrato ad enclimaque succisum Berosus Chaldaeus dicitur invenisse; scaphen sive hemisphaerium dicitur Aristarchus Samius, idem etiam discum in planitia; arachnen Eudoxus astrologus, nonnulli dicunt Apollonium; panthium sive lacunas, quod etiam in circo Flaminio est positum, Scopinas Syracusius [my emphasis]; pros ta historumena, Parmenion, pros pan clima, Theodosius et Andrias, Patrocles pelecinum, Dionysodorus conum, Apollonius pharetram, aliaque genera et qui supra scripti sunt et alii plures inventa reliquerunt, uti conarachnen, conicum plinthium, antiboreum. Item ex his generibus viatoria pensilia uti fierent, plures scripta reliquerunt. Ex quorum libris, si qui velit, subiectiones invenire poterit, dummodo sciat analemmatos descriptiones.

Berosus the Chaldaean is said to have invented the semi-circular dial hollowed out of a square block and cut according to the latitude; Aristarchus of Samos, the Bowl or Hemisphere, as it is said, also the Disk on a level surface; the astronomer Eudoxus, or as some say Apollonius, the Spider; Scopinas of Syracuse, the Panthium or Ceiling, of which an example is in the Circus Flaminius; Parmenio, the Dial for Consultation; Theodosius and Andrias, the Dial for All Latitudes; Patrocles, the Dovetail; Dionysodorus, the Cone; Apollonius, the Quiver. The persons already enumerated and many others left behind them other discoveries, such as the Conical Spider, the Conical Ceiling and the Antiborean. Many also have left instructions for making Hanging Dials for travellers. From such works anyone who wishes can find instructions, provided he understands the method of describing the analemma. ${ }^{133}$

Previous editions of Vitruvius had adopted in place of panthium the variant plinthium proposed by Fra Giovanni Giocondo in his I 5 I I edition. The Latin plinthium is itself a hapax, but it is taken to be a transliteration of the Greek plinthion, meaning 'brick' or 'square'. Granger's reassertion of the manuscript reading panthium appeared in successive reprints of the Loeb edition in I944, I956, I962 and I970. ${ }^{134}$ Other editors, however, continued to favour Fra Giocondo's alternative, acknowledging the manuscript reading in the apparatus criticus, but without further comment. ${ }^{135}$ Eventually, in I985, in the Loeb edition too the word panthium was replaced by plinthium, and a footnote was added:

Prof. Granger's belief that panthium of $\mathrm{H}$ is right, that the Pantheon of Rome is meant, and that this was a great sundial, is not credible. ${ }^{136}$

\footnotetext{
131 Romulus: Coarelli I983, followed by La Rocca 20I 5: 52-3; rebutted by Ziolkowski 2009: 36-7.

132 Granger I932 and I933.

133 Granger I934: 254-5 (my emphasis). British Library, MS Harley 2767, f. I36v.

134 I am grateful to the library staff at the University of Liverpool and the Guildhall, who very kindly confirmed to me this reading in the 1962 and 1970 imprints respectively.

135 Fensterbusch 1964: 444, line 17; Soubiran 1969: 30.

136 Granger I944: 254, n. 4. Further imprints appeared in 1995 and 1998.
} 
With this terse dismissal, apparently the contribution of the ageing general editor of the Loeb series and formidable Latinist E. H. Warmington (I898-1987), the consensus manuscript reading was dropped and has been virtually ignored ever since. ${ }^{137}$

The question, however, deserves revisiting. Giocondo's reading is sometimes justified by the occurrence of the phrase 'conicum plinthium' a few lines later. Yet as the 'conicum plinthium' is listed among the inventions of 'many others (alii plures)', it has no connection with the device earlier attributed to Scopinas, so there is no reason to believe that the same word was employed there. Moreover, the translation of plinthium as 'ceiling' in this later phrase in the 1985 edition seems to have been over-influenced by the first context where panthium/plinthium appears alongside lacunar; in fact, the Greek $\pi \lambda$ iv $\theta$ iov is never found with this meaning elsewhere, and 'conicum plinthium' seems to be better translated as something like 'conical box'. Indeed, in the first passage, the Harleian's reading 'panthium' makes clearer sense. The 'i', which possibly confused Giocondo, accustomed as he was to the Latinate form pantheum, is recognizable as a long vowel corresponding to the Greek diphthong - $\varepsilon-$-. So the Latin panthium would naturally correspond to the Greek $\pi \alpha \dot{v} \theta \varepsilon i o v$; the variation from the later form pantheum is understandable as a phonetic spelling of the kind that Vitruvius' contemporaries are known to have followed.138 Given that the Greek word had only recently been introduced into Latin, such a phonetic spelling would be entirely natural.

There is no mention of Scopinas of Syracuse by other ancient authors, but he appears again in Vitruvius, in his very first chapter (I.I.I7), in a group of prestigious scientific names whom the author presents as intellectual models. Of the others listed there, Philolaus and Archytas of Tarentum belong to the fifth or early fourth centuries B.C., while the others - Aristarchus of Samos, Apollonius of Perge, Eratosthenes of Cyrene, and Scopinas' fellow-Syracusan Archimedes - flourished in the third century B.c. Therefore, it would be unlikely that Scopinas lived much later than this. As the word etiam indicates, however, the version in the Circus Flaminius at Rome was a later copy of Scopinas' invention. One might object that this location would exclude the Pantheon, which lies some way north of that area in its strict sense. ${ }^{139}$ Vitruvius elsewhere uses the phrase in a way that would be consistent with this precise definition. ${ }^{140}$ However, the toponym 'Circus Flaminius' also has a wider meaning that refers to the whole district of the Campus Martius, which, within some fifteen years of Vitruvius' work, would become the Augustan Regio IX. ${ }^{141}$ The name of this region in all probability goes back to even before its creation in 7 B.C., when it was considered as the area outside the city walls previously known as the Prata Flaminia where plebeian contiones and military gatherings took place. ${ }^{142}$ As Vitruvius does not use the alternative phrase 'Campus Martius' anywhere in his work, it is not clear that he could not have been using the phrase 'Circus Flaminius' more widely, to denote the whole built-up area of the

137 Rowland 1999 and Schofield 2009 do not even mention the manuscript reading.

138 Suet., Aug. 88; cf. Granger I932: 58, listing examples of such phonetic spellings in Augustus' Res Gestae.

139 For the location and character of the Circus Flaminius, see Wiseman I974.

140 Vitr., De Arch. 4.8.4, of the Temple of Castor in the Circus Flaminius.

141 Soubiran I969: 253 cites Sen., Ben. 5.16.5 (Caesar's 'castra in Circo Flaminio'), Mart. I 2.74.2 ('de Circo pocula Flaminio', in contrast to crystal from the Nile) and CIL VI.97I3 ('[nu]mmulario de Circo Flaminio') as examples of the toponym in its wider sense, although he decides in favour of its more precise meaning in this passage. For the likely completion of Vitruvius' work before 22 B.C., see Rowland I999: 4-5.

142 Suet., DJ 39.3, on the other hand, refers to 'the Region of the Campus Martius', but such an alternative name is understandable at a time when considerably more of the Campus had been built up; in Vitruvius' time, it would have been natural to have called the region after the dominant built-up zone, the Circus Flaminius. In the later Regionary Catalogues the name covered the area of the Campus Martius as far north as the Column of Marcus Aurelius, making it clear that it was possible to think of buildings within that zone such as the Pantheon as an appendage to the Circus Flaminius, even though in its strict sense that toponym referred to an area further south. 
southern Campus Martius, of which the Circus Flaminius stricto sensu was simply the most prominent feature. The Baths of Agrippa and adjacent Pantheon could be regarded as part of this loosely defined zone. ${ }^{143}$

What kind of a sundial Agrippa's Pantheon was, emerges from the alternative name given by Vitruvius. The manuscripts give two versions of this alternative name: the Harleian and the majority of later manuscripts read lacunas ('gaps' or 'hollows'); but most modern editions, including the later imprints of Granger's text, prefer lacunar ('coffer' or 'coffered ceiling'), the reading of the Gudianus and Scletstatensis manuscripts. As lacunas would have to be interpreted in the same sense of 'coffering' (the coffers being considered as 'hollows'), there is not much to choose between the two: while the lectio facilior 'lacunar' may be preferable being the more normal term for this architectural feature, the plural lacunas makes more sense for a structure that involved more than one coffer. In either case, the building must have included some kind of coffered ceiling in which the shadow of the sun was cast through a central opening on different coffers at different times of day and year. Scopinas' panthium was most likely analogous to the smaller roofed spherical sundial type well-attested in Italy in the first century B.C., in particular to the variant with a complete ceiling, where the sun radiates through a pierced hole to produce a bright image of the sun on the otherwise shadowed face of the dial. ${ }^{144}$

It may seem counter-intuitive to consider Agrippa's Pantheon as the sundial devised by Scopinas. Although a detailed recent case has been made for the present building serving such a function, most scholars today dismiss the possibility that Agrippa's building did so as 'too ambitious for the evidence'. ${ }^{145}$ Yet, since contemporary Roman bath complexes at Pompeii are accompanied by sundials, it would be no surprise to see one adjacent to the Baths of Agrippa, of which the Pantheon has been recognized as an integral component. ${ }^{146}$ Moreover, the building, which it is now clear had the same shape and dimensions as the later rotunda, is oriented almost precisely north-south, and the meridian line to the north confirms the astrological focus of the zone. It is true that nothing more is known about its construction or layout. ${ }^{147}$ Yet the most plausible recent reconstructions of the space imagine a domical wooden roof with wooden coffers comparable to the exedras of the Forum Augustum which have identical radial dimensions. ${ }^{148}$ There is some pictorial evidence for how this might have looked. A round structure painted in the early imperial period on the upper part of both the north and south walls of the 'Tablinum' in the House of Caecilius Iucundus at Pompeii consists of a series of Ionic columns supporting a coffered dome (Fig. 32). The dome is coloured brown to indicate its timber construction, with a starry scene painted in the inner section of the dome, and an oculus incorporated at the centre of the structure analogous to the hole in the roof of a small spherical sundial with its lip functioning as

\footnotetext{
143 Likewise, the Theatre of Pompey seems to be included among 'the three theatres' that were part of the 'second plain' in Strabo's account of the Campus Martius (5.3.8): 'with numerous encircling colonnades, sacred precincts, three theatres, an amphitheatre, and lavish temples, all very close together'. The 'three theatres' appear again in the Regionary Catalogues for Regio IX Circus Flaminius where they are explicitly named as those of Balbus, Marcellus and Pompey.

144 Gibbs I976: 23-4, 6I.

145 La Rocca 201 5: 69. For the present Pantheon as a sundial, see Hannah 2009: I45-54.

146 Roddaz I984; Ziolkowski 2009: 36.

147 Gruben and Gruben I997: 3 I and 54-7 have argued that the present threshold block of 'africano' marble was a modified version of the original threshold of Agrippa's building. For further suggestions about the form of Agrippa's Pantheon, see La Rocca 20I 5: 53-72, especially 69-7I where he suggests a distribution of the divine statues that reconciled the seven planetary deities with the canonical arrangement of the gods in the sixteen regions of the celestial templum. This argument, however, assumes that the Agrippan building was identical to the later building in its layout of seven exedras and interior division into sixteen segments.

148 La Rocca 2015: 65-7.
} 
a gnomon. The wooden coffers of such a building might have helped to mark astronomical data in accordance with the moving spotlight of the sun in the manner of preserved smaller stone spherical sundials with horizontal equinoctial and solstice lines crossed by vertical hour lines. ${ }^{149}$ Indeed, given the considerable awareness of the art and architecture of Augustan Rome in early imperial Pompeii, the building shown in the House of Caecilius Iucundus might even itself have been a schematic representation of Agrippa's Pantheon omitting the statuary and other decorative details. ${ }^{150}$

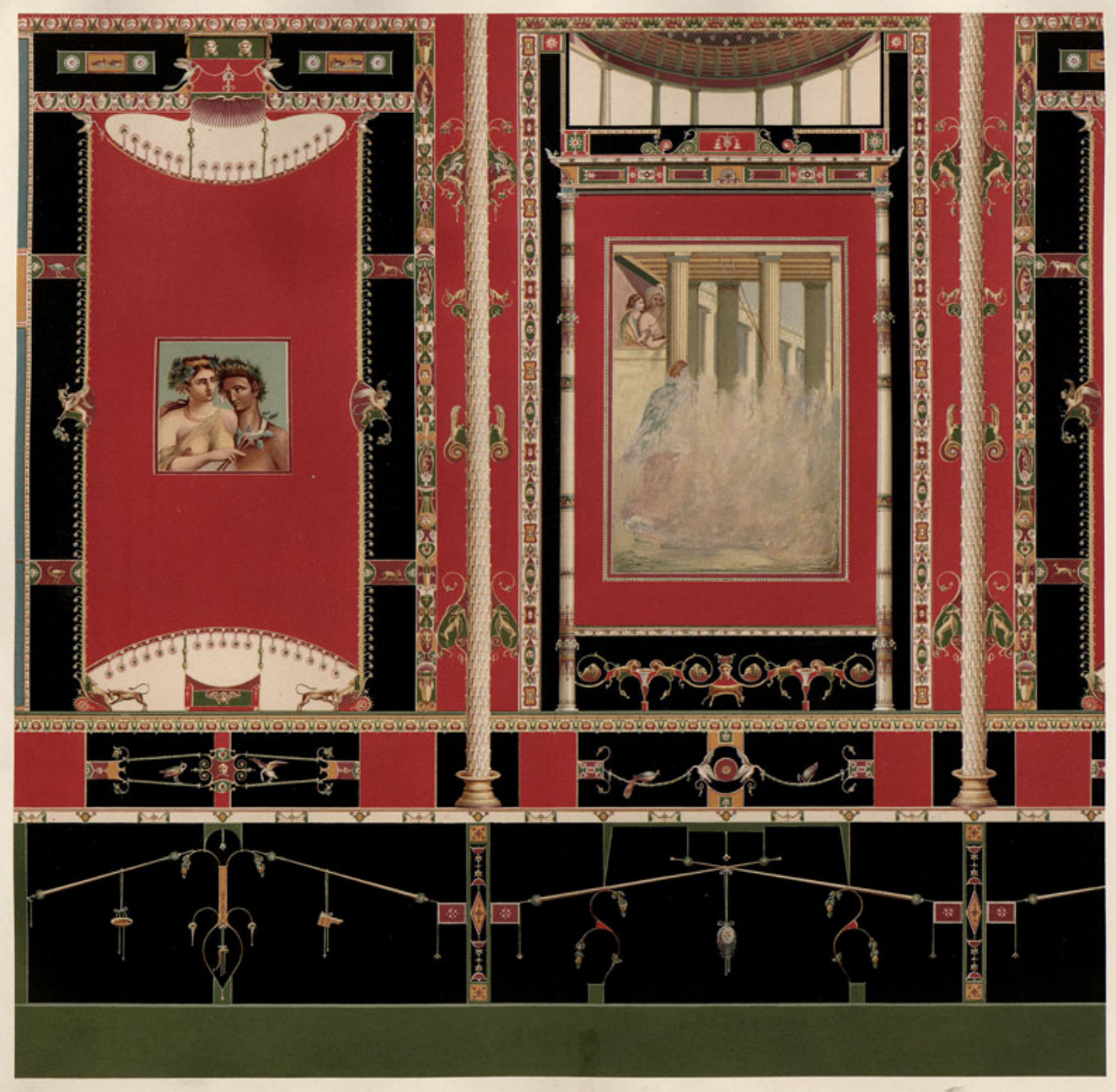

FIG. 32. Restored drawing of wall-painting from the tablinum of the House of Caecilius Iucundus (Pompeii V.r.26); from A. Mau, Geschichte der dekorativen Wandmalerei in Pompeji (Berlin, I882), Taf. XIII. (Photo: Heidelberg University Library)

149 Gibbs 1976: I94-218.

150 Agrippa's building also included the caryatids mentioned by Pliny, which are usually assigned to the attic below the dome. Other resonances of Augustan Rome in Pompeii, apart from the cuirass of Holconius Rufus (above), include the wall-paintings of Aeneas and Romulus outside the door of the House of M. Fabius Ululitremulus (IX.I3.5) derived from the Forum Augustum (Zanker I988: 202-3, fig. I56) and the paintings 
So, as Mommsen long ago hypothesized, it is likely that images of the gods representing these heavenly bodies stood within Agrippa's building just like the twelve gods in the Pantheon/Tychaion at Antioch. Although many different deities are attested in literary, epigraphic and visual sources across the Roman Empire as being subsumed within their number, ${ }^{151}$ the list of twelve 'Consenting Gods' established at the lectisternium of 2 I 7 B.C. provided a certain fixity to the membership of this group at Rome. Arranged in pairs, as if for the divine feast that they were intended to share, were the twelve Olympians of the Greek world: Jupiter and Juno; Neptune and Minerva; Mars and Venus; Apollo and Diana; Vulcan and Vesta; Mercury and Ceres. ${ }^{152}$ The poet Ennius arranged their names into a pair of hexameters:

\section{Iuno Vesta Minerva Ceres Diana Venus Mars \\ Mercurius Iovis Neptunus Vulcanus Apollo.}

These same twelve gods also had an astronomical significance, being custodians of the signs of the zodiac. The Augustan poet Manilius listed them, with the addition of the Mother of the Gods, Cybele, beside the Father of the Gods, Jupiter (2.433-52):

His animadversis rebus quae proxima cura?
noscere tutelas adiectaque numina signis
et quae cuique deo rerum natura dicavit,
cum divina dedit magnis virtutibus ora,
condidit et varias sacro sub nomine vires,
pondus uti rebus persona imponere posset.
Lanigerum Pallas, Taurum Cytherea tuetur,
formosos Phoebus Geminos; Cyllenie, Cancrum,
Iuppiter, et cum matre deum regis ipse Leonem;
spicifera est Virgo Cereris fabricataque Libra
Vulcani; pugnax Mavorti Scorpios haeret;
venantem Diana virum, sed partis equinae,
atque angusta fovet Capricorni sidera Vesta;
e Iovis adverso Iunonis Aquarius astrum est
agnoscitque suos Neptunus in aethere Pisces.
hinc quoque magna tibi venient momenta futuri,
cum ratio tua per stellas et sidera curret
argumenta petens omni de parte viasque
artis, ut ingenio divina potentia surgat
exaequentque fidem caelo mortalia corda.

What step must one take next, when so much has been learnt? It is to mark well the tutelary deities appointed to the signs and the signs which Nature assigned to each god, when she gave to the great virtues the persons of the gods and under sacred names established various powers, in order that a living presence might lend majesty to abstract qualities. Pallas is protectress of the Ram, the Cytherean of the Bull, and Phoebus of the comely Twins; you, Mercury, rule the Crab and you, Jupiter, as well as the Mother of the Gods, the Lion; the Virgin with her sheaf belongs to Ceres, and the Balance to Vulcan who wrought it; bellicose Scorpion clings to Mars; Diana cherishes the hunter, a man to be sure, but a horse in his other half, and Vesta the cramped stars of Capricorn; opposite Jupiter, Juno has the sign of Aquarius, and Neptune

of the portico of the Temple of Apollo plausibly modelled by Holconius Rufus on the Portico of Philippus (Heslin 20I5).

151 See Long I987: 360-3 for an extensive index of deities who were at some point somewhere identified as members of the twelve.

152 Livy 22.9.7-IO, I0.9; a later lectisternium, in I79 B.C. refers to heads of the gods on couches. 
acknowledges the Fishes as his own for all that they are in heaven. This scheme too will provide you with important means of determining the future when, seeking from every quarter proofs and methods of our art, your mind speeds among the planets and stars so that a divine power may arise in your spirit and mortal hearts no less than heaven may win belief. (trans. G. P. Goold)

This was the divine and celestial Pantheon. Agrippa's Pantheon can be imagined to have contained statues of all this group with Apollo and Diana perhaps doubling up as the Sun and Moon. Surviving representations not only confirm the pre-eminence of these twelve, but suggest how they might have been positioned. The so-called 'Altar of the Twelve Gods' from Gabii (Fig. 33), now in the Louvre, is arranged in a circular structure like the Pantheon, with twelve divine busts set around the upper face of a low cylinder; their symbols interspersed on the sides of the cylinder between zodiacal reliefs show the work's astrological associations and suggest how the walls of Agrippa's Pantheon sundial might have been articulated. Some of the heads are restored, but a paired arrangement can be reconstructed. At the top of the disc stood the busts of Mars and Venus, with a smaller Cupid between them, as on the Algiers Relief. Around the rest of the perimeter, the other 'Consenting Gods' were divided into five other pairs: Jupiter and Juno; Vulcan and Ceres; Neptune and Minerva; Mercury and Vesta; Apollo and Diana. ${ }^{153}$ The 'Ara Borghese' in the Louvre, a triangular base for a candelabrum, confirms these pairings, but presents them rather differently, with groups of four deities on each of its three sides, above a row of Neo-Attic female figures: above the Graces, Jupiter and Juno, Neptune and Ceres; above the Seasons, Apollo and Diana, Vulcan and Minerva; and above the Fates, Mars and Venus, Mercury and Vesta. ${ }^{154}$ This arrangement, also attested on a votive relief from Tarentum of the fifth century B.C., seems to have been more or less canonical from an early period. ${ }^{155}$ In Agrippa's Pantheon, the Augustan gods Mars and Venus, joined by Cupid, took prominence within this group. Agrippa subsequently inserted Caesar alongside them to stand for the new Sidus Iulium. ${ }^{156}$

That was not, however, the end of the story. As we have seen, the Golden Age imagery of the Secular Games encouraged the return of the imagery of Caesar's star. After that time, the originally planned name of 'Pantheum Augustum' might have re-appeared in the manner of other sacred complexes such as the 'Ara Pacis Augustae' or, later, the 'Aedes Concordiae Augustae'. The epithet has left no trace in the sources at Rome; in the Arval Acts of A.D. 59 the building is called simply 'Pantheum'. ${ }^{157}$ But it appears in the western provinces, in the context of the imperial cult. Two inscriptions from Spain record the construction and dedication by a sevir augustalis of a sacred offering to '(the) Panthe(um) August(um)' and the dedication of '(a) [Pa]ntheum Aug(ustum)'. ${ }^{158}$ The Algiers Relief belonged to a similar context. Despite its name, it was found in Carthage and brought to Algiers only because of the realities of nineteenth-century imperialism.

153 Louvre MA 666. Long I987: I4-I6 (Gabii I) and 294-6. The Albani Puteal and the compita of Pompeii also represent the twelve Olympians.

154 Louvre MA 672. Long I987: 37-8 (Rome 8) and 272-3.

155 Cook I9I4-40: ii, I057.

156 This is the same combination of divinities as suggested by La Rocca 2015: 76, though he adds that Romulus-Quirinus was probably also included.

157 CIL VI.204I, line 50 = ILS 229 (I2 January 59). Here the building occurs as the site of the indictio, when the Arval brethren met to announce their sacrifice; the building seems to have been chosen because of its status as a sanctuary of the Gens Iulia, and the members will have met, not in the Pantheon itself, but in the front portico, visible to the public. See Scheid I990: I76-7, 460-4.

158 CIL II.3030 (Alcala la vieja): '[P]an[t]he[o] Aug(usto) sacrum L. Iulius L. lib. Secundus ... IN ... STOC IIIIII vir aug(ustalis) [d]e s. p. f. c. idemque dedicavit'; $A E$ I972.254: '[Pa]ntheo Aug(usto) sacrum / [---] Flavius Baeticus lib(ertus) rei p(ublicae) / Muniguensium accepto loco / ex decreto ordinis D[---]'. Cf. the signum Panthei bequeathed by a seviralis at Astigi: AE 1988.725; Garcia 1987-88: 368. Also the dedication at Maxula in North Africa: $A E$ I937.73; Poinssot 1936. 


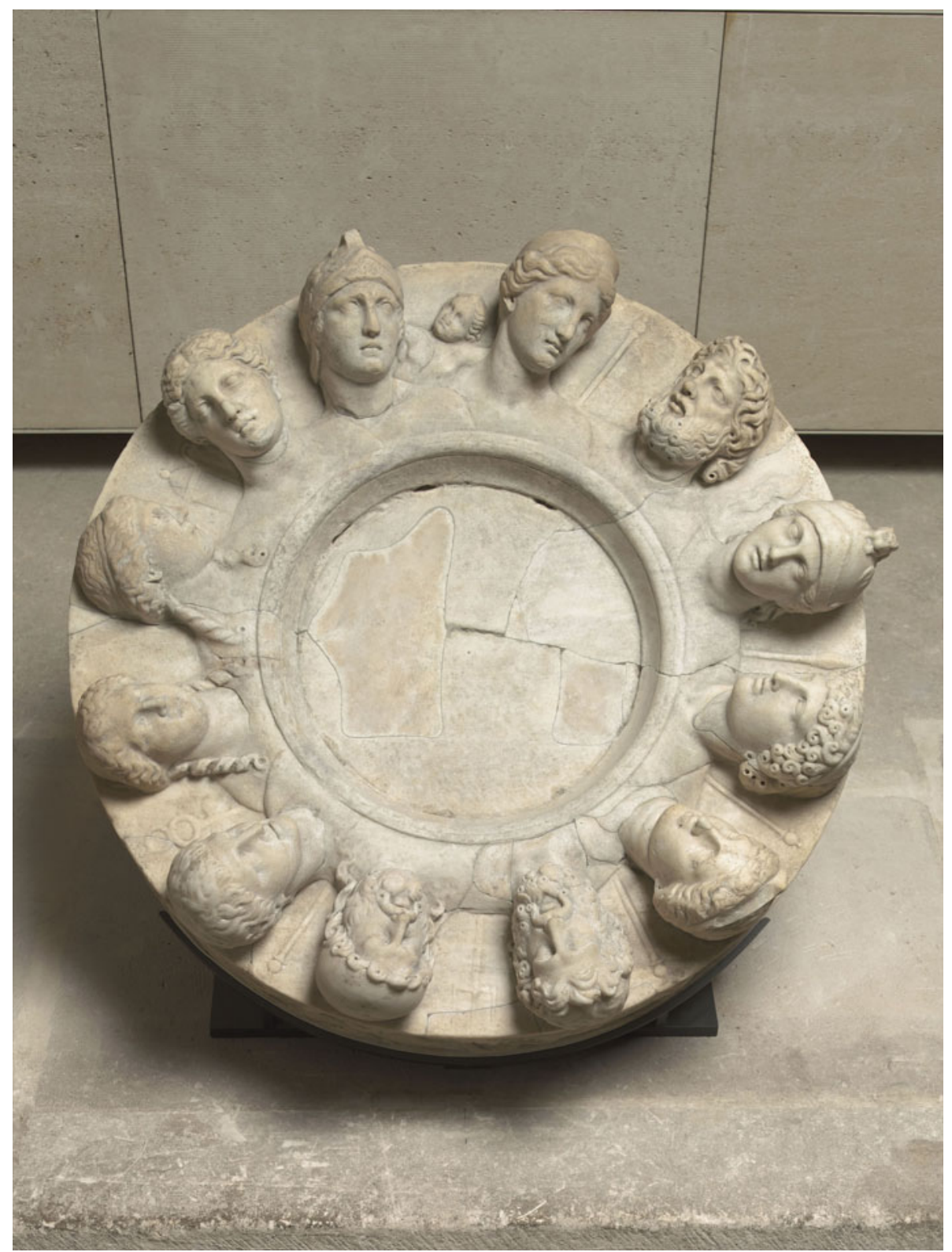

FIG. 33. So-called Altar of the Twelve Gods from Gabii. Paris, Musée du Louvre Ma666. (Photo: @ RMN-Grand Palais (Musée du Louvre) / Hervé Lewandowski)

Found in independent Tunisia at la Malga (Maalga/Maalka), not far from the Byrsa hill where the civic basilica was later excavated, the relief was signalled to the colonial authorities in June 1856 and sent by the French consul general Léon Roches the following year to the museum in Algiers, then the centre of the French protectorate. ${ }^{159}$ 
The material, form and dimensions of the relief suggest that it was part of an altar to which also belonged a second, even more famous panel, found earlier, in 1838 , in the same area of Carthage and donated in 1856 by Roches to the Louvre, which represents a copy of the 'Tellus' relief of the Ara Pacis. ${ }^{160}$ A second altar of similar size, style and date was also found in Carthage, bearing other images derived from high-profile Augustan sites in Rome: Aeneas, Anchises and Ascanius, a recognized statue group in the Forum Augustum; Apollo seated on a griffin, a well-known image on the cuirass of the 'Prima Porta Augustus' statue; the goddess Roma seated on a pile of arms, generally accepted as another of the reliefs on the precinct wall of the Ara Pacis; and a man offering a libation at an altar. ${ }^{161}$ The original location of these two altars is unknown, but their reliefs suggest a similar purpose. Each appears to mimic reliefs or statuary groups from Rome that were strongly associated with Augustan ideology. By analogy, therefore, this confirms that the relief representing Mars, Venus and the Deified Julius also reproduced a statuary group from the capital. The presence of the relief of Aeneas from the Forum Augustum on the other altar might suggest that this group belonged to the same complex; but the reliefs on the second altar were all taken from different monuments. Moreover, as we now know, the statue group cannot have belonged to the Temple of Mars Ultor.

This ensemble was emulated at Carthage, either later in the reign of Augustus or perhaps under Tiberius, to judge from the portrait features of the figure in the relief. The Tellus relief is also later than the Ara Pacis on which it was modelled, ${ }^{162}$ presumably the product of a local workshop executed in the early Julio-Claudian period. ${ }^{163}$ The reproduction of another monument from the Campus Martius that had then become associated with the imperial cult is easily explained if the relief adorned an altar of that cult. It was unsurprising that the model chosen was a group that celebrated Augustus' avenging of the Deified Caesar. Besides, the star on the head of the Deified Julius not only identified the figure and emphasized his divinity, but showed the celestial meaning of the Pantheon.

Because nothing is known of the interior layout of Agrippa's Pantheon, the arrangement of statuary there cannot be pursued further. There is little or no archaeological evidence of the rebuilding by Domitian recorded by some sources. ${ }^{164}$ By contrast, the rebuilding under Trajan and Hadrian is exceptionally well-preserved. The remainder of this article will therefore consider the statues in the Hadrianic Pantheon. Nissen's method in assigning statues to different parts of the building (Fig. 2) was simple. He envisaged an image in each of the eight tabernacles projecting from each wall between the exedras and on

160 Louvre MA I 838, NIII 975. Wuilleumier I928: 40. The marble for the Algiers Relief perhaps came from the Djebel Filfila quarries near Skikda in Algeria, as suggested by J. Röder: Kraus I979: 245. The marble from Cap de Gard near Hippo Regius is also possible (Hurst 1975: 27), but Filfila is not much further from Carthage. For more recent analysis of these marbles, see Herrmann et al. 2012.

161 Rives I995: 52-4.

162 Matz I960: 294-6, overturning an older view that both the Carthage relief and the Ara Pacis derived from a common Hellenistic original (Wace I910: I76; Richter I95 I: 672).

163 Vienna, Kunsthistorisches Museum (formerly Venice, Palazzo Grimani). Kraus I979: 245; Gsell I892: 393. There is no reason, however, to follow the suggestion of Kraus that the Louvre relief is as late as Claudian in date and was not a literal rendering of the prototype in Rome. The inclusion of specifically Egyptian landscape details at the lower left corner has suggested to Ansel (2012) that the relief was retouched in the Hadrianic period; however, her dating to the Augustan period because of the citation of Augustan monuments cannot be sustained. A date in the second century A.D. is given by Lazzaro I99I: I I I, fig. 20, following Jentel I98 I: 380 . 164 Gruben and Gruben I997: 59; La Rocca 201 5: 62. 
either side of the entrance and of the rear apse, and in each of the seven exedras, apart from the rear one opposite the entrance where he placed the statues of Venus and Mars. He arbitrarily placed altars in front of these images, round ones in front of the tabernacles and rectangular before the exedras, to indicate their cultic function. But this straightforward principle of arrangement does not exactly correspond to the layout of the building. Assigning a statue to each of the corner tabernacles is easy enough; but placing just one divine image in each of the six lateral exedras (Fig. I), as here, is not. First of all, the column screens in front of them would potentially have obscured any large statuary inside. Second, Renaissance representations of the interior indicate clear locations for statuary, similar to the niches in the tabernacles. Sebastiano Serlio's plan shows three niches in the back wall of the two curvilinear exedras perpendicular to the main axis; and, in the four trapezoidal exedras on the diagonals, three niches in the back walls and one each in the side walls. In the present state of the building, the three niches in the back wall are still visible in the trapezoidal exedras, but those in the lateral walls cannot be verified, while those of the curvilinear exedras are entirely concealed behind the re-workings of the nineteenth century. Nonetheless, this placement of statuary makes sense in terms of the architecture of the building. As Palladio's reconstruction shows (Fig. 34), statues placed in the niches at the back of the exedra, rather than on the floor in the centre of the exedra, would not be obscured by the column screens. Each one could be viewed through the spaces between the columns. ${ }^{165}$ These locations provide for a total of thirty-four individual statues: six in the two curvilinear exedras; twenty in the four trapezoidal exedras; and eight within the eight tabernacles. This is the figure calculated by Pirro Ligorio in his Turin notebooks. ${ }^{166}$ Like Palladio, Ligorio also allowed for another ten in the openings of the attic, making forty-four in all, though there were actually fourteen of these openings and, despite their strategic positions above the aedicules and above the centre of the exedras, it is not clear that they were intended for statuary. In addition, he considered the central exedra at the rear, which lacks niches for statuary, as the site of 'the colossal statue of Jupiter Ultor', to whom Renaissance commentators believed the building was dedicated, ${ }^{167}$ and the ressauts of the two columns on either side of this exedra as supports for statues of Juno and Minerva.

It is difficult to fit this evidence of surviving statue niches to an arrangement of twelve planetary deities in a ring, as for Agrippa's Pantheon. In the later building, the arrangement of wall niches for statuary fits a division not into pairs, but into two groups of three (in the curved exedras), four groups of five (in the other exedras), and one set of six (in the aedicules). The only surviving representation that shows an arrangement in threes is a square marble base in the Capitoline Museum, which presents three gods on each of its four sides, but the combinations have little in common with the conventional pairings: Jupiter, Mercury and Venus; Apollo, Vesta and Diana; Vulcan, Mars and Juno; and Neptune, Minerva and Ceres. ${ }^{168}$ The thirty-four available spaces in the Trajanic-Hadrianic Pantheon must have been filled quite differently.

At first sight, these statue locations have no obvious hierarchy; each of them appears equally distributed from the centre. But there is some distinction made by the character of the architectural ornament. In the first place, there is a clear spatial differentiation in

165 A. Palladio, I Quattro Libri dell'Architettura (Venice: Dominico de' Franceschi, I 570), Book IV, Chapter XX, after p. 74 .

166 P. Ligorio, Turin notebooks, fol. $48^{\mathrm{r}}$.

167 Fulvio I 5 I3: Book 2, fol. 42v, lines 4-5. The comment of the Census of Ancient Art Known in the Renaissance (inserted by J. N. D. Hibler) is simply: 'It is not clear why Fulvio considers the Pantheon to be a temple of Jupiter Ultor.' Census, record no. 43529 . Cf. P. Ligorio, Turin notebooks, fol. $48 \mathrm{v}$. We return to this question at the end of this paper.

168 Capitoline Museums, inv. I961. Long I987: 34-5 ('Rome 4'). 


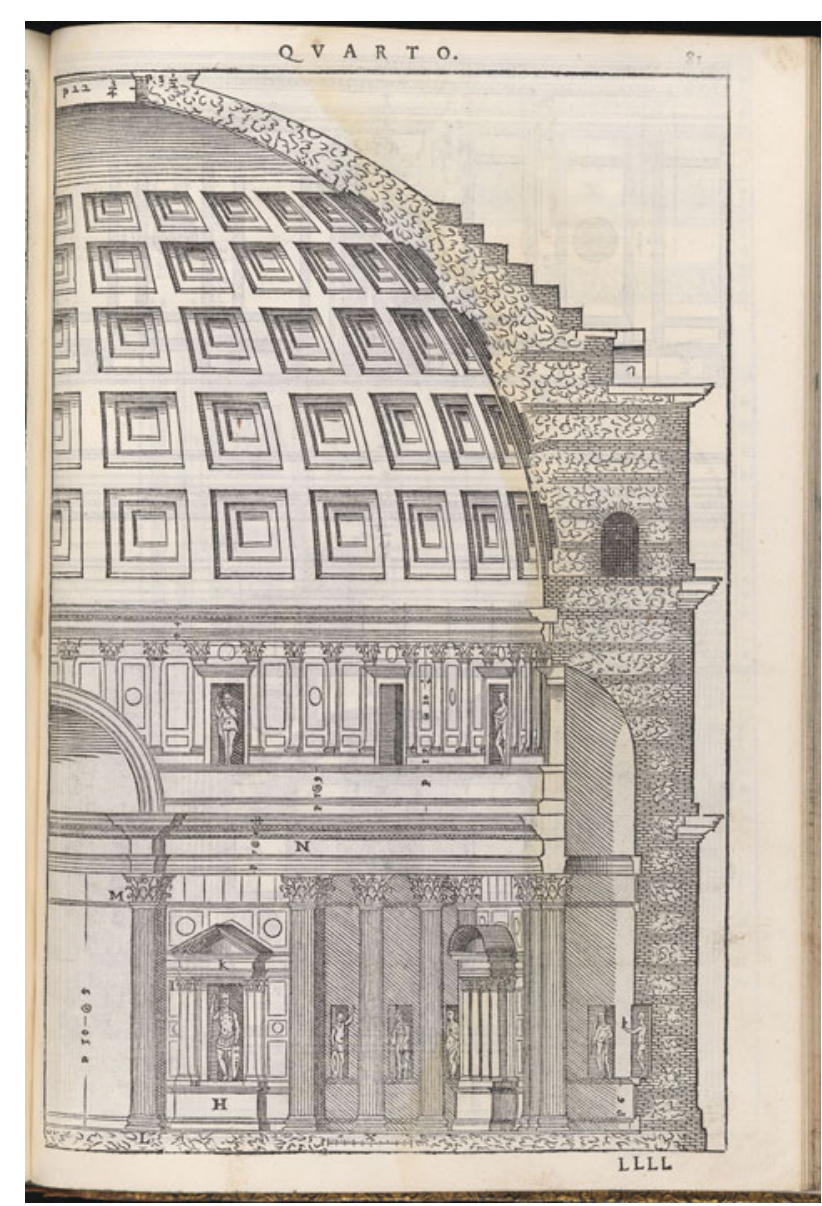

FIG. 34. Reconstruction of the Pantheon interior by Andrea Palladio. From I Quattro Libri (Venice: Dominico de' Franceschi, I 570), Book IV, Chapter XX. (Photo: Edinburgh University Library)

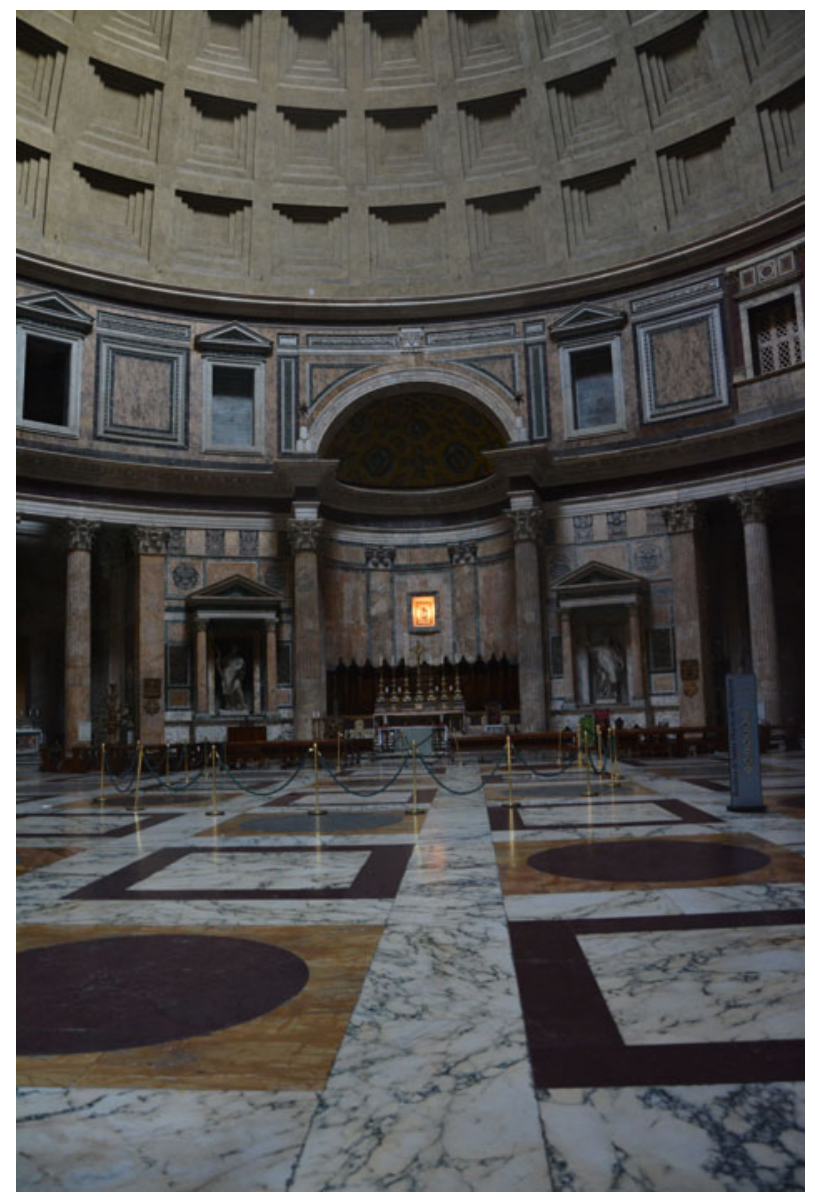

FIG. 35. Pantheon, rear apse. (Photo: author) 
the use of imported coloured marble for the column screens in front of the exedras, all of which use columns divided into cabled fluting in the lower part and conventional fluting above. The three curved exedras on the axis of the entrance and perpendicular to it have columns of Docimian marble with its distinctive purple vein ('pavonazzetto'), while the four rectangular exedras on the diagonals are of yellow Numidian marble ('giallo antico'). As the fluting of the columns mark all these spaces out as of particular significance, so the costly material and the curving rear wall of the two exedras perpendicular to the entrance axis give a higher status to the statues placed here. The higher value of Docimian marble is highlighted by Strabo; and in Diocletian's Price Edict of A.D. $30 \mathrm{I}$ it is the most expensive marble listed, with a value of 200 denarii per cubic foot, surpassed only by porphyry. ${ }^{169}$ The latter material, however, is used for the columns of the eight aedicules that project inwards from the walls of the rotunda.

The most conspicuous space, however, is the rear exedra (Fig. 35). This is where Nissen places the cult statues of Mars and Venus, whom he considers to have been the 'incumbents (Inhaber)' of the temple. As we saw, the potential of this space as a location for statuary was also recognized in the Renaissance. Such a position opposite the entrance is well attested in those temples in Rome where the site of the cult statue is still observable; ${ }^{170}$ it also corresponds to Vitruvius' prescription that the cult statue of a temple should be visible from the entrance. ${ }^{171}$ But there are several other ways in which the rear exedra is given prominence. First, while it is curved like the two perpendicular exedras, there are no niches in the back wall; the dispensation with wall niches suggests that a grander scale of statuary was intended here than in the other exedras. Second, the exedra is not screened by columns, so its contents would have been fully visible from within the building and from the entrance, not half-concealed. Third, the direction of the marble squares on the pavement (Fig. 36), accentuating the entrance axis, leads the eye towards a point of visual focus in the rear exedra. Fourth, the greater height of the rear exedra gives it an additional prominence and hierarchical importance. Fifth, it is crowned by an arch rather than a straight entablature like the other exedras, which provides a visual frame for the contents of the exedra. Sixth, it is flanked, on the outside, by two free-standing columns, which mark out the distinctiveness of this space. Finally, the effect of these columns and the absence of a column screen is to open up this rear space as an integral part of the building's interior, rather than a separate exedra like the others. ${ }^{172}$

At the same time, the material and treatment of these flanking columns mark out in an even more pronounced manner the transition to a space of higher importance than the rest of the rotunda. They are of the same Docimian marble as the columns in the screens of the lateral curved exedras, but of a richer vein, as Serlio also noted. ${ }^{173}$ Apart from the partially cabled fluting, a feature which they share with the column screens of the other curved exedras, the shafts of the columns on each side of the apse are richly carved, ending both below (Figs 37-38) and above (Fig. 39) in a form like an arrowhead.

Similar columns are found in several places in Rome, many of them re-used in medieval churches, but the finer version found in the Pantheon's columns, in which the 'arrowhead' takes a three-dimensional, convex form, is limited to cases of the Trajanic-Hadrianic period including the rebuilt phase of the Temple of Venus Genetrix (now re-used in the front of the Lateran Baptistery) (Figs 4O-4I) and the 'Piazza d'Oro' of Hadrian's Villa at Tivoli (Fig. 42). ${ }^{174}$ The fragments from the 'Piazza d'Oro' belonged to fluted giallo antico

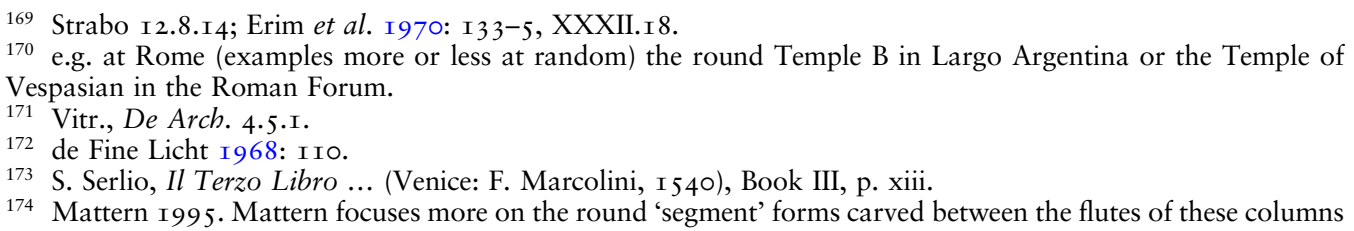




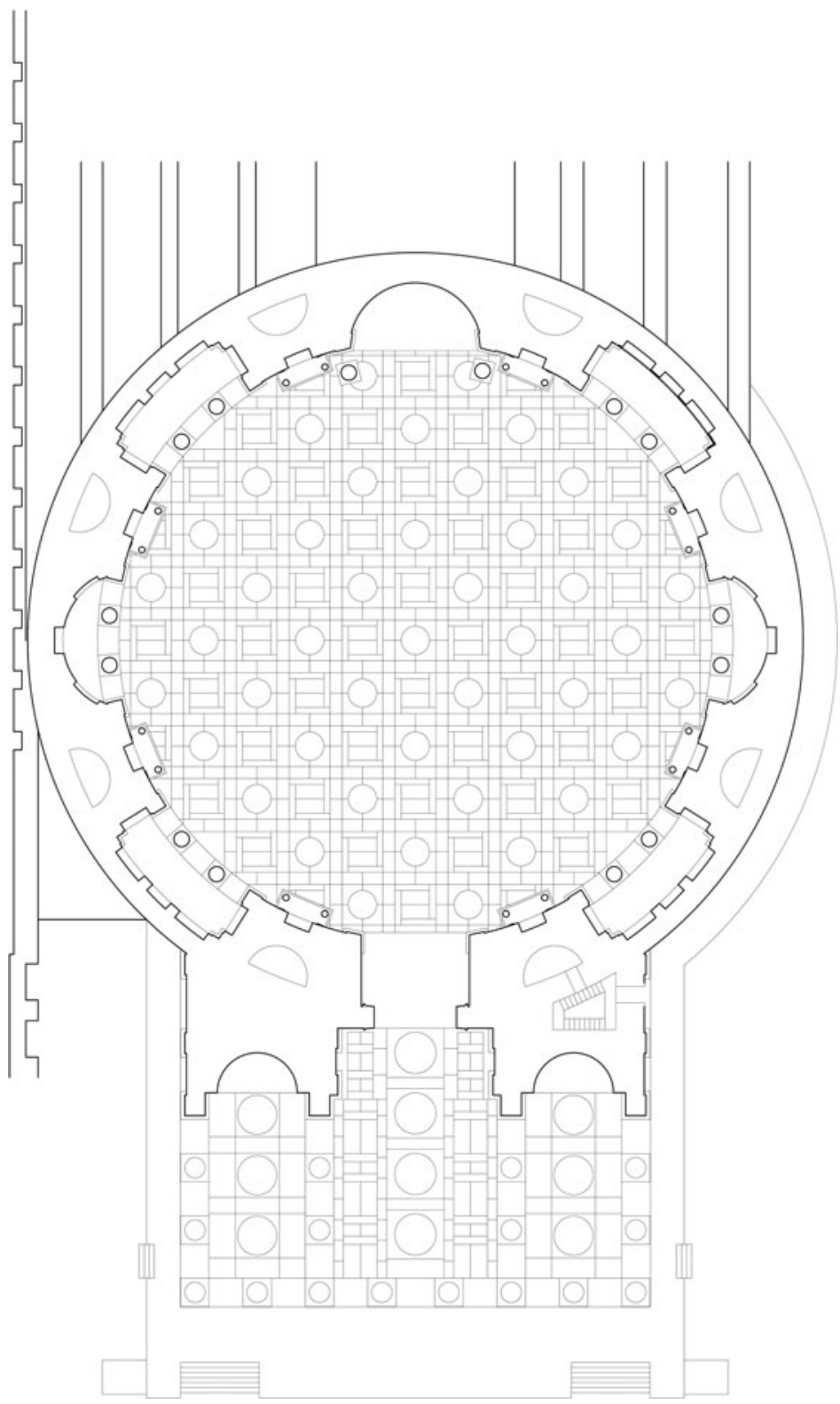

FIG. 36. Plan of the Pantheon with floor paving marked. (Drawing by Mark Wilson Jones, with his permission)

column shafts ornamented with semi-circular fillets ending in arrowhead forms, which, like the Pantheon, are attributed to the main axis of the hall facing towards the large fountain; ${ }^{175}$ and, as in the Pantheon, pilaster responds against the walls mirrored the

and does not adequately distinguish the different types of the arrowhead ends. In the other versions, the 'arrowhead' consists of two concave 'furrows' either side of a central ridge.

175 At the 'Piazza d'Oro' there are two types of bases, one quite common with two scotias with a moulding with several convex fillets between the two concave mouldings, used for the middle columns of the Peristyle and for 


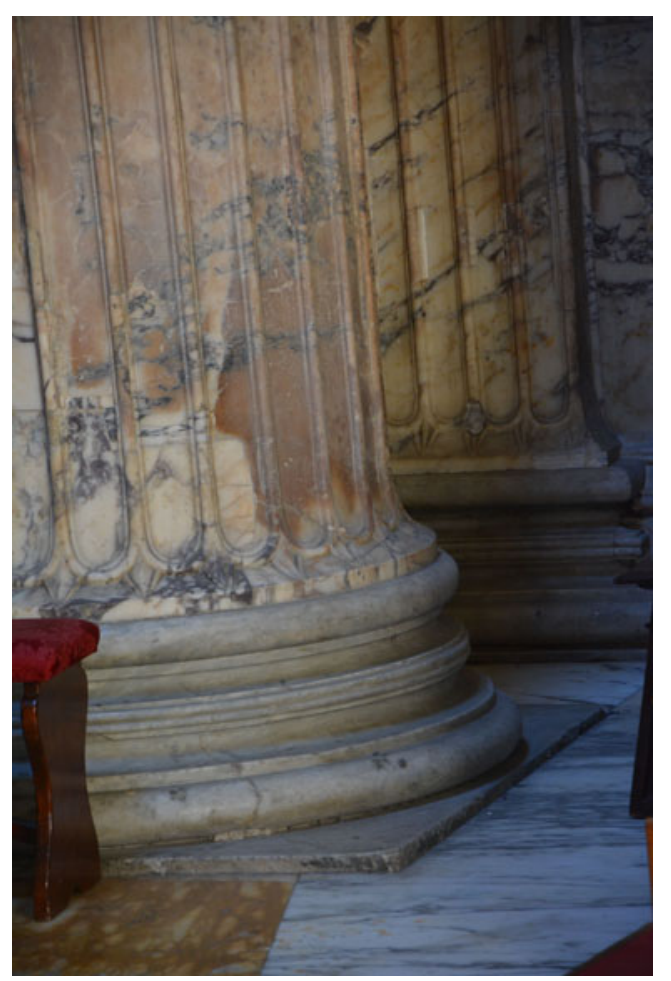

FIG. 37. Pantheon, rear apse, left side. Detail of lower fluting of free-standing columns and pilasters. (Photo: author)

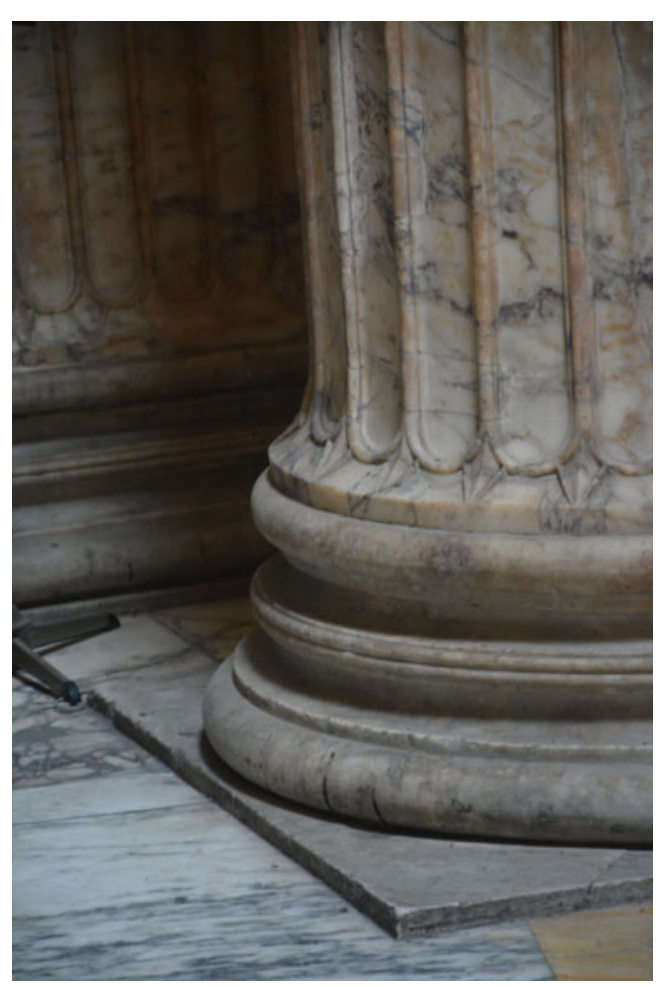

FIG. 38. Pantheon, rear apse, right side. Detail of lower fluting of free-standing columns and pilasters. (Photo: author)

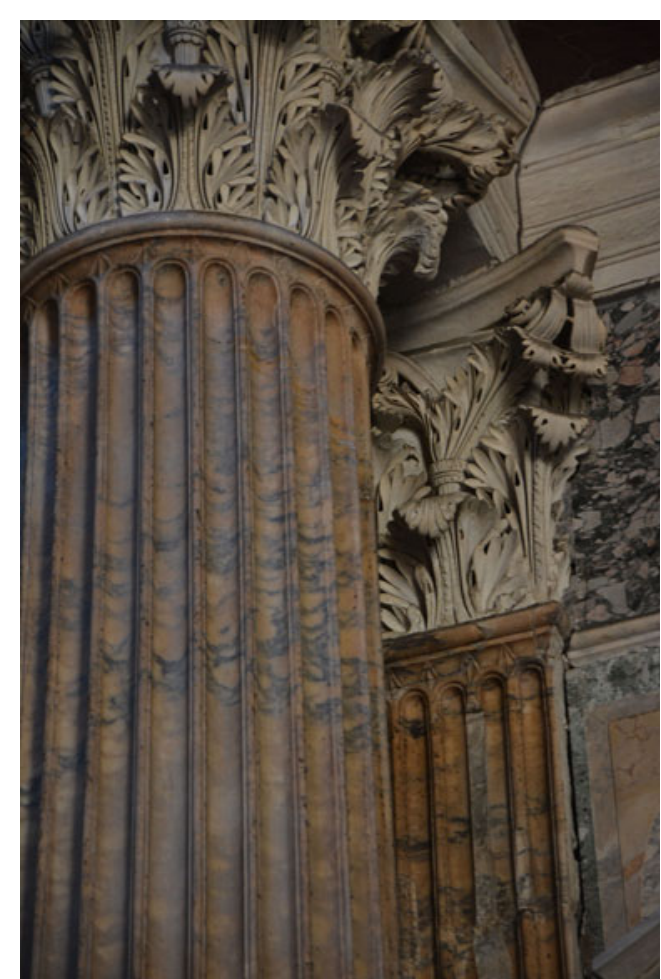

FIG. 39. Pantheon, rear apse, right side. Detail of upper fluting of free-standing columns. (Photo: author) 
columns. ${ }^{176}$ The same arrowhead forms also appear in the probably Hadrianic columns of the portico of the Dei Consentes, re-erected in the fourth century. The fragment from the Temple of Mars Ultor seems to have come from the interior of the temple (Fig. 43), and it is tempting to assign it to a restoration attested in the Hadrianic period, but the more elongated form of the arrowhead motif, found also in the Theatre of Marcellus, raises the possibility that it belongs to the original Augustan phase. ${ }^{177}$ Otherwise, with the possible exception of a slightly different leaf motif found in the Stadium of the Domus Augustana on the Palatine, the Trajanic-Hadrianic examples may be the earliest examples of such a motif, of which later versions take a simpler, concave form. ${ }^{178}$

It is clear then that the rear exedra was designed for a special purpose. However, as was mentioned at the start of this paper, not everyone is agreed on its religious use. Thirty years ago, Peter Godfrey and David Hemsoll suggested that this apse was the location of the tribunal where, according to Dio, Hadrian sometimes gave judgement. ${ }^{179}$ The spatial character of this area, integrated with the central space, might give some support for this theory. Tribunals in basilicas were sometimes set up in exedras, but they were generally placed on a raised platform and, although the later altar in this apse is elevated above the floor of the rotunda, Renaissance sketches consistently illustrate that there was no raised step in antiquity. This may not matter in itself - one could imagine the use of a wooden platform, though not perhaps repeating the curvature of the wall behind - but there is a more compelling objection to Godfrey and Hemsoll's theory. In other instances of buildings other than basilicas being used for tribunals, the presiding individual did not sit inside the building, but outside. The clearest example is Julius Caesar, who reportedly received the senators seated before the Temple of Venus Genetrix in his new (and presumably still incomplete) Forum Iulium. ${ }^{180}$ In the Roman Forum, the other site Dio mentions as used by Hadrian for such judgements, the tribunal of the urban praetor was placed in a range of open-air locations, while the Tiberian Temple of Castor had tribunalia at the sides of its front stairs. ${ }^{181}$ The clinching argument is that, as the excavations undertaken in 1996-97 below the portico of the Pantheon have shown, both the original Pantheon and its Trajanic-Hadrianic rebuilding were of this form too, a templum rostratum with the front portico standing on a podium with two lateral stairways. This structure was apparently used as a speaker's platform and almost certainly for Hadrian's tribunals. ${ }^{182}$

those of the Nymphaeum, the other as here with just one scotia between two smooth tori which is limited to the columns of the central hall and the adjacent spaces; the column shafts, all restored on the basis of minute fragments, similarly differ in both type and material: those of the Peristyle with smooth shafts alternately of granite and cipollino, those of the rooms to the south of coloured marble and fluted, the fluting profiled by a fillet which follows its full height and ends both at the imoscape and at the summoscape with a schematic ivy leaf motif. Conti I970: I5, pl. VII. (restored with insertion of original fragments: GFN no. 9407); Hansen I960: I 8 and pl. I5.

176 Hansen I960: I7-I 8, fig. This is rather different from the examples of ornamental motifs at the top of the flutes of Ionic columns known from Hadrianic Asia Minor, such as the Temple of Zeus at Aezanoi and temples at Notion, Heraclea Pontica and Cyzicus, which revive the similar form found in the Hellenistic dipteral temple, the Smintheion. Naumann I979: 68, pls 2ob and 53b-f; Barresi 2003: 310, pl. 35.4 .

177 Comune di Roma, inv. FA 5460-I. A Hadrianic restoration of many temples and the Forum of Augustus is attested by SHA, Hadr. I9.Io, but the reliability of the Scriptores for such details is notoriously questionable and there is no clear archaeological evidence of Hadrianic work in the Forum.

178 Stadium: Iara 20I 5 .

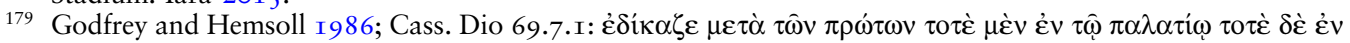

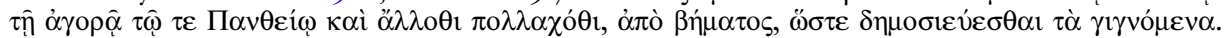

180 Suet., DJ 78. I. The tribunal area in front of the portico, accessed by two side stairways, would have been an obvious location for this. See Amici I99I.

181 Urban praetor: Kondratieff 2010 surveys the different sites in the Forum and its transfer to the exedra of the Forum Augustum. Castor: Gorski and Packer 201 5: 293-7, fig. I 8.8.

182 Virgili and Battistelli I999; La Rocca 20I 5: 6I, fig. 2.8. 


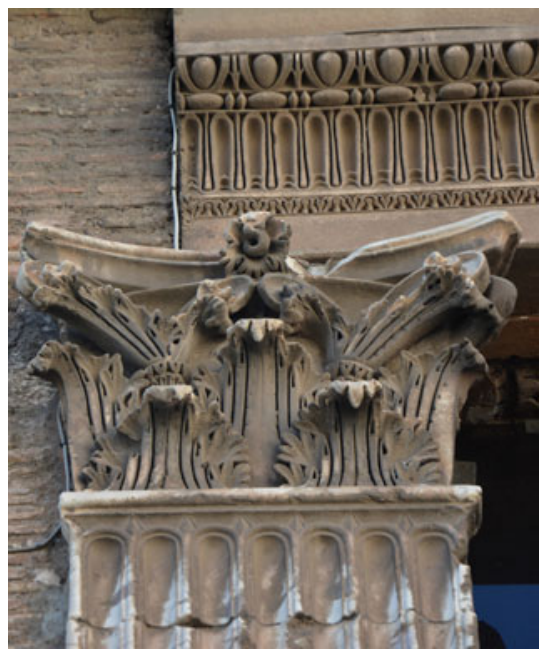

FIG. 40. Rome, Lateran Baptistery. Re-used pilaster from exterior entrance, upper fluting. (Photo: author)

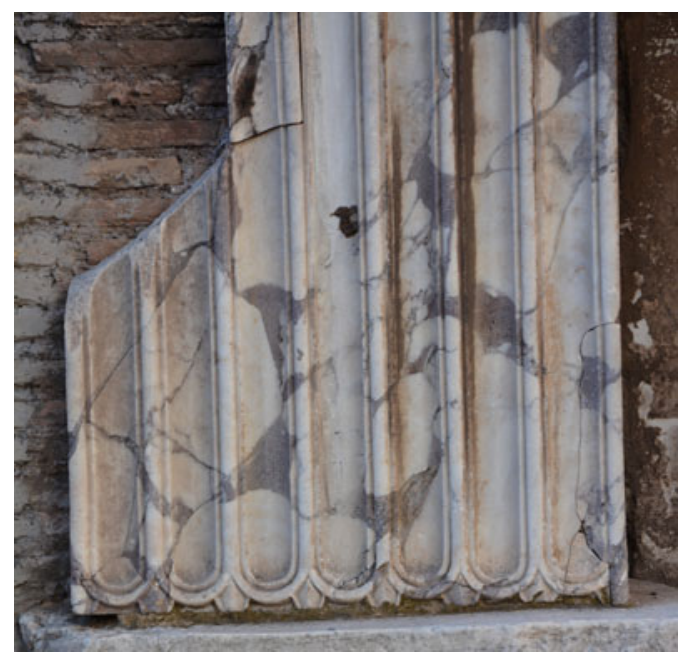

FIG. 4I. Rome, Lateran Baptistery. Re-used pilaster from exterior entrance, lower fluting. (Photo: author)

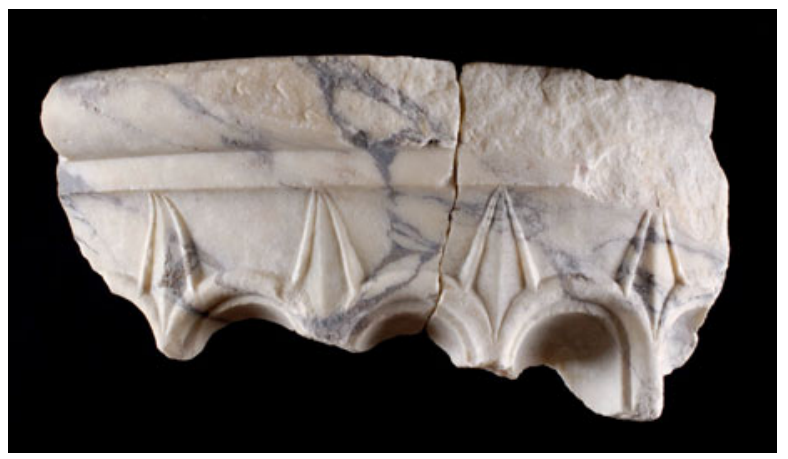

FIG. 43. Fragment of pavonazzetto fluted column. Museo dei Fori Imperiali. Rome, Sovrintendenza Capitolina ai Beni Culturali, Mercati di Traiano - Museo dei Fori Imperiali 5460-I. (Photo: Stefano Castellani)

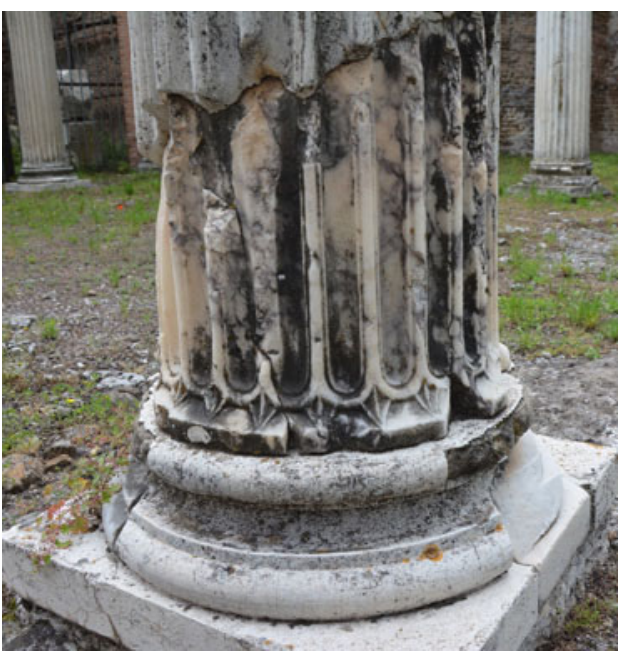

FIG 42. Tivoli, Hadrian's Villa. Piazza d'Oro. Detail of column fluting. (Photo: author) 
Godfrey and Hemsoll adduce two other arguments for this use of the rear apse of the Pantheon. First, a marble slab from the wall of the apse is said to have been inscribed with the name of Hadrian's empress Sabina. This tradition was first reported by Stefano Piale in a lecture to the Papal Archaeological Academy in I826. Piale related how he had been informed by the secretary of the academy, Filippo Visconti, that Sabina's name could be read 'in the marbles of the tribune of the Rotunda'. ${ }^{183}$ This statement is imprecise, but, wherever the inscription was placed, it is hard to see how it could confirm the use of the apse suggested by Godfrey and Hemsoll. Whether inscribed directly on the columns or on the marble slabs of the rear wall, it seems to lack the character of a formal inscription. Second, it is argued that the rear apse is the only one of the exedras of the building that could be entered from the rear (Fig. I). Some support might be found from the access to the tribunals of Roman basilicas. The basilica tribunal at Pompeii is accessed from side stairs to north and south; however, these are approached from the side rooms at the back of the side colonnades, rather than from the rear of the building. ${ }^{184}$ So there is no clear archaeological support for Godfrey and Hemsoll's thesis. Indeed, the rear exedra of the Pantheon is not the only exedra of the rotunda with access from the rear: the same feature occurs in the south-west exedra, where there is no suggestion that this space was used for a tribunal. Neither of these passages is as might be expected for an imperial entrance. In fact, they appear to have been cut through at a later stage. It has been suggested that they were used to bring cartloads of martyrs' bones from the catacombs into the new Sancta Maria ad Martyres. ${ }^{185}$ However, this story seems to have been invented in the Counter-Reformation: attributed to Cardinal Cesare Baronio in I586, it does not reflect actual practice of the cult of relics in the seventh century. ${ }^{186}$ The passages at the back of these two exedras require a different explanation. Perhaps they were constructed not to bring martyrs' relics into the rotunda, but to take out the antique statuary.

There is, of course, a strong visual reason for seeing this exedra as an imperial tribunal which may subconsciously have influenced Godfrey and Hemsoll's thinking. That is the arch overhead, which would have crowned a figure below in a way familiar from imperial imagery of Late Antiquity. As already noted, the rear exedra differs in this respect from the others, which are all crowned by rectilinear entablatures. Only the entrance opposite is covered by a huge arch. In the light of such architectural imagery, it would be natural to compare the rear exedra of the Pantheon with the celebrated Missorium in Madrid (Fig. 44), on which the Emperor Theodosius I is shown giving judgement beneath a similar arch, flanked by his sons Arcadius and Honorius. ${ }^{187}$ In this 'architecture of authority' with deliberate frontality, the rounded arch above the central ruler's head 'sets him apart ... as a cosmic arch symbolic of the glorification and epiphany of the emperor'. ${ }^{188}$ However, to read Dio's account of Hadrian's tribunals in this way would be highly anachronistic. ${ }^{189}$ When Caesar sat between the front columns of the Temple of Venus Genetrix in 44 B.C. to hold court, the senators took even this as an affront. ${ }^{190}$ If, barely a century and a half later, Hadrian had held court inside the Pantheon, within the rear apse, and surrounded by divine statuary, it would have been

183 Piale I 833: 5.

184 Ohr I99I: 24, pl. 38. Later buildings at Rome, Ostia and Pergamum modelled on the Pantheon lack an entrance at the rear of the main niche: Briggs I930; Rasch I984 and I993; Ziegenaus I98I.

185 MacDonald i976: I 8.

186 Pasquali I996: 24-5 and 21 5; Thunø 201 5: 235. For the cult of relics in the early Middle Ages, see McCulloh I980 and Thacker 2007.

187 For the identifications, see Oliver 2002: 708-9.

188 Kiilerich 2000: 276-8; also Oliver 2002.

189 For the potential of the arched lintel to become transformed into such a frame (which had not happened by Hadrian's reign), see Thomas 2007: 40-6, 6I-5.

190 Maiuro 20I0: I9I. 
regarded as even more outrageous. It was little more than half a century since Nero's shocking presidency in a dining-room of his palace with similar imagery. It was only possible for Theodosius to take up an analogous position because of the developments in imperial ritual that took place during the Tetrarchy and the Constantinian period. ${ }^{191}$

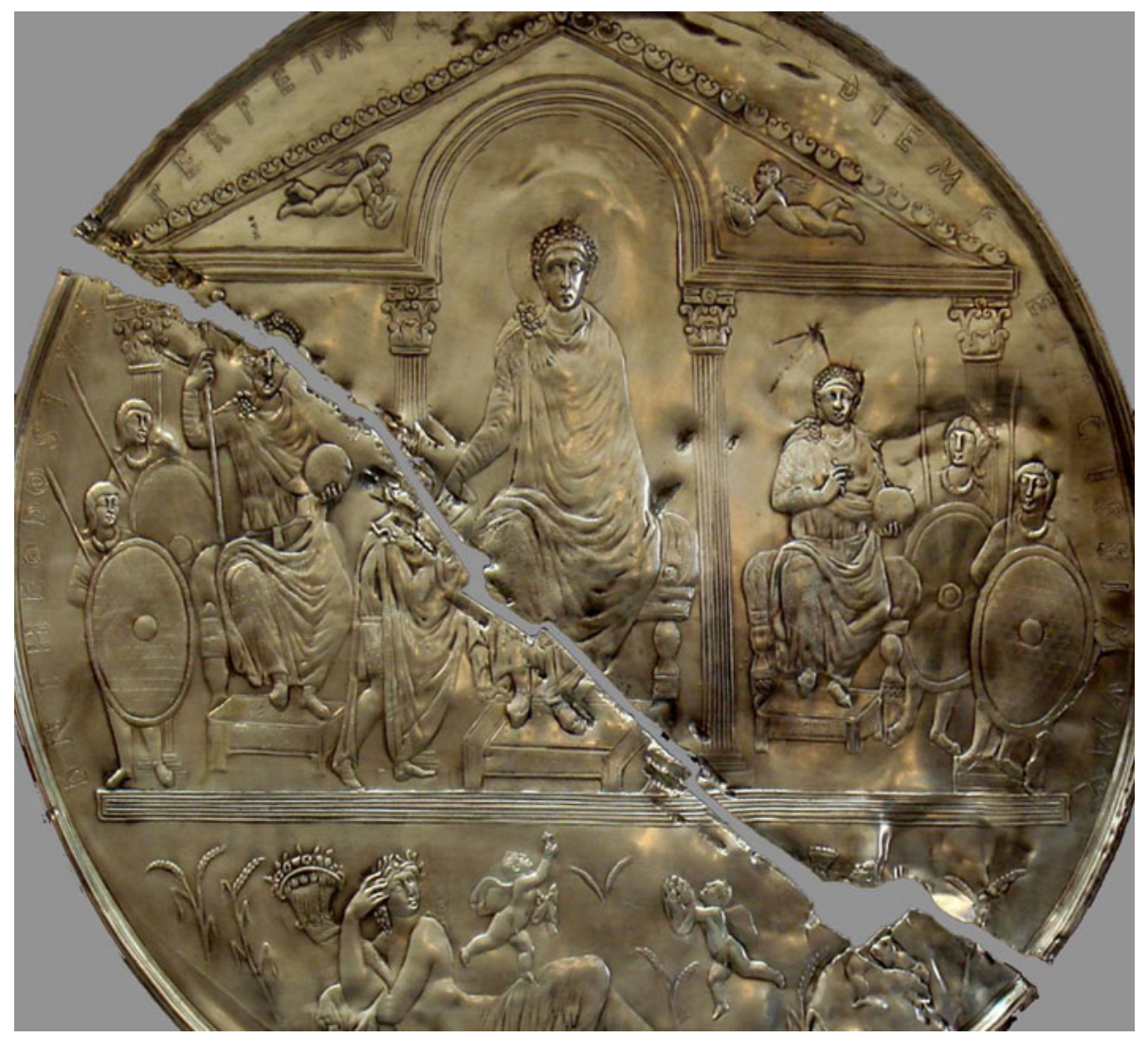

FIG. 44. Missorium of Theodosius, Madrid. (Photo: German Archaeological Institute Madrid, neg. no. D-DAI-MAD-WIT-R-I 86-97-02 / Peter Witte)

Overall, therefore, there is no strong argument for locating the tribunal of the emperor in the rear apse. On the other hand, its use for statuary is to be expected. It is not only the axial location that favours this interpretation. The free-standing columns which define this space offer a further argument. In the embellishment of the cella of the Temple of Venus Genetrix, which was almost contemporaneous with the rebuilding of the Pantheon and perhaps reflects a similar interest in the buildings associated with the deified dictator, pilasters with ornamental bases and decorated with the same 'arrowhead' motif were added on either side of the entrance to the rear apse; in that case there is no doubt that their rôle was to add further emphasis to the setting of the cult statue of Venus Genetrix. ${ }^{192}$ The similar columns of the 'Piazza d'Oro' also originally marked off an

191 See, e.g., MacCormack I98I. For imperial ceremonial in later palaces see Dyggve I94I and Francovich I970.

192 Amici I991: 94-5, figs I 52-3, I 56 and I60; Ulrich I993. 
area for statuary in the niches behind the fountain basin, apparently statues of Venus and the Nymphs, suited to a nymphaeum. ${ }^{193}$

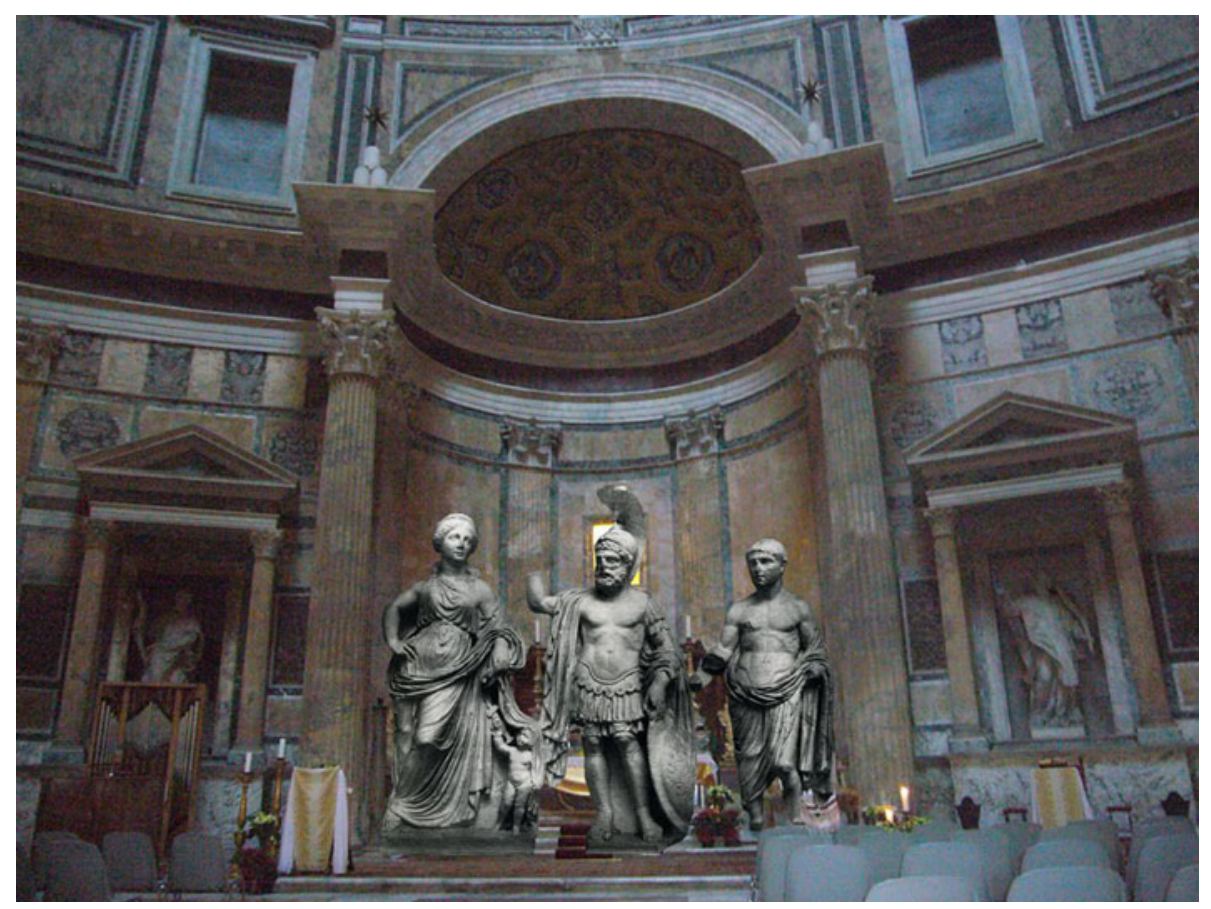

FIG. 45. Pantheon, rear apse, with statues from Algiers Relief superimposed. (Photo montage: author)

The number and less conspicuous location of the statues arrayed in niches around the rotunda of the Pantheon seen by Dio in the early third century easily explain the writer's vagueness in referring to the majority of agalmata displayed there. By contrast, the most visible place for particular statues of note was the rear apse, with its hierarchical position and lack of column screen in front. It is highly likely, therefore, that the three statues he mentions, those of Mars, Venus and the Deified Julius, were located there; the juxtaposition of these three figures on the Algiers Relief shows that, already in the early reception of Agrippa's Pantheon, they were considered to be a significant triad. Moreover, not only are the three statues of the Algiers Relief easily adapted to the dimensions of the rear apse of the Pantheon (Fig. 45), but the decoration is even structured to accommodate their positions. The rear wall of the exedra is divided by shallow fluted pilasters of pavonazzetto marble, the same material as the columns flanking the exedra on the outside and the column screens of the other two curved exedras. They have no apparent function beyond mere ornament. However, to the viewer from the body of the rotunda, they serve to separate the three statues of the group

193 The columns have now been re-erected in the curvilinear columnar screens of this hall, with copies made of cement for the other columns; but only one of these columns has an original marble termination. The statues found in this area include a Venus, a Hypnos and nymphs; and a frieze of mythological marine figures ran above the architrave: MacDonald and Pinto I995: I48. For further details, Ashby I908: 229, citing MS Vat. Lat. 5295 , f. I8r: 'on each side of the apse, statues of Venus, two of which were removed to the garden of the Cardinal on the Quirinal "with other figures which represented nymphs of the ocean, where was Inachis, or the Egyptian Venus, and Hipponoe"'; cf. Raeder I983: I 29. 
visually from one another, and the uniformity of material with the outer columns creates a unified aesthetic frame for the figures. It is hard to explain this detail unless the exedra was designed to enclose a three-figure statue group of this kind. Finally, this reconstruction may even help to explain the inscription found in the rear wall of the apse. The Empress Sabina's common association with Venus, and the similarity of the hairstyle with central parting in some of her later portraits (Fig. 46) to the Venus of the Pantheon group (Fig. 3), offer a reason for her name to be inscribed behind the statue of Venus in this group. ${ }^{194}$ It is not clear how formal this inscription was, but it was probably in the nature of a graffito, an illicit comment on the resemblance of the emperor's consort to the city's patron goddess.

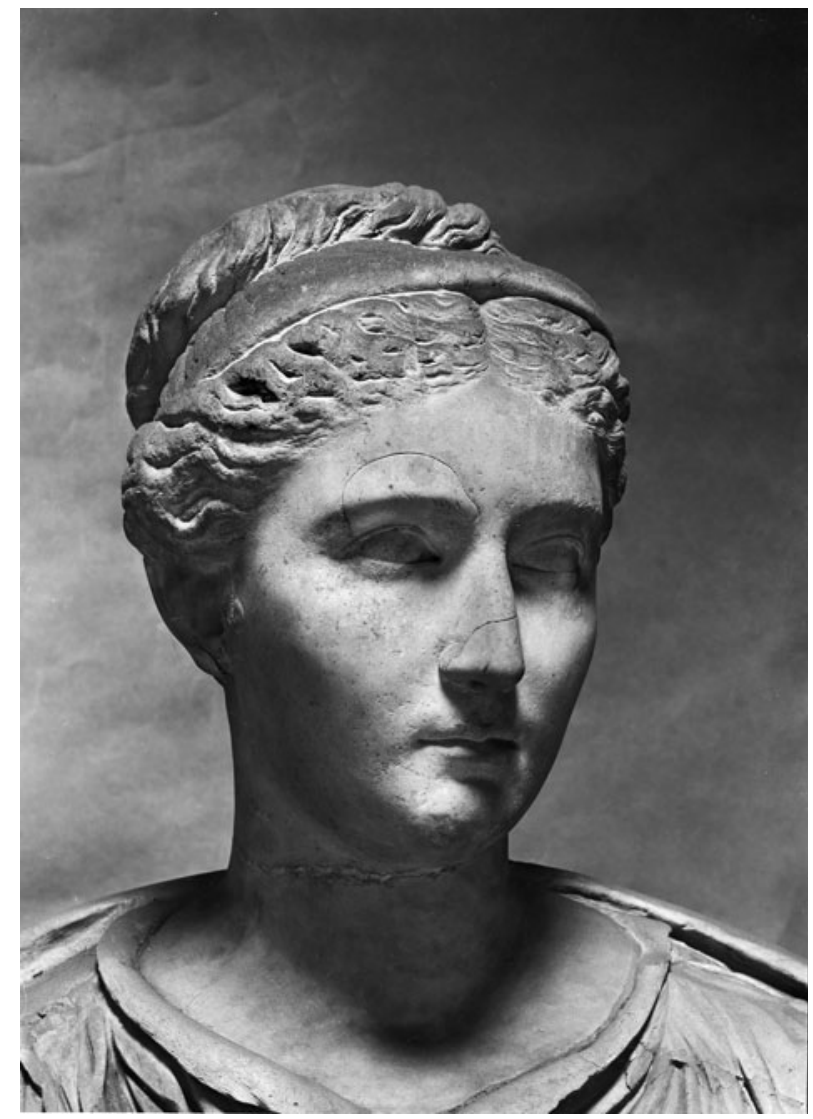

FIG. 46. Marble portrait head of Sabina attached to extraneous body. Antike Sammlung, Staatliche Museen zu Berlin, Sk 496 - Preussischer Kulturbesitz.

This article has argued that the images of greatest cultic significance, and perhaps the only ones in which we can reasonably assume a continuity between the Agrippan arrangement and those of the early second-century building, were those of Mars, Venus and the Deified Julius. These will have occupied the main exedra of the Trajano-Hadrianic

194 Comment by G. B. De Rossi on lecture by Lanciani, 3 February I 888, on 'mittelalterliche Verwendung von Säulen der Basilica Aemilia', in Anon 1888: 95: 'slabs of Phrygian marble belonging to the ancient restorations of the Pantheon.' Platner and Ashby 1929: n. 3: 'The name of Sabina, his wife, is said to have been read on the marble of the main apse (not on the pavonazzetto columns); see HJ 585 , n74.' See above. 
building, facing the entrance and flanked by free-standing columns and pilasters of high-quality pavonazzetto marble with cabled fluting and distinct arrowhead forms at either end. The fact that these columns are positioned over and across the axis of the paving (Fig. 36) may suggest that they were an after-thought to the original plan, but they cannot have been completed later than the restored rotunda as their entablatures are integrated with the entablature of the rest in the inner order. They should perhaps be seen as a Hadrianic feature adding emphasis to the principal statues, executed during the final phase of the building's construction when the interior order of the rotunda was finished. ${ }^{195}$

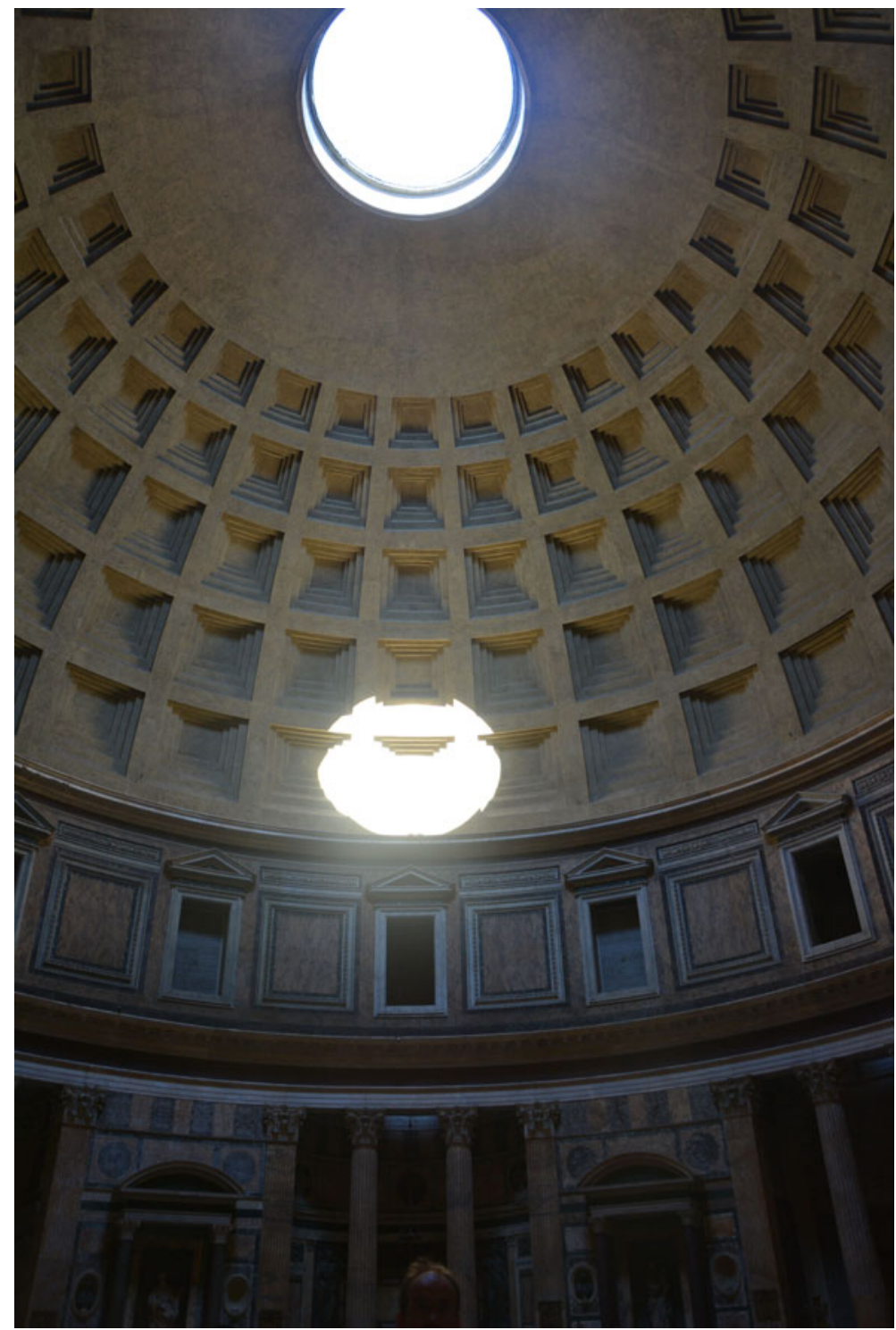

FIG. 47. Pantheon, east exedra, with alignment of sunbeam at summer solstice at I6h50. (Photo: author, 2 I June

195 DeLaine 2015: I89 includes the finishing of the interior order of the rotunda within 'Years 8-9' of the building's construction history, probably corresponding to A.D. I $22-\mathrm{I} 23$.

$20 I 6)$ 
The extensive preservation of the structure offers further room for speculation about the possible identity and arrangement of the other deities in the thirty-four niches around this main group. The alignment of the sunbeam on the coffers above the eastern exedra in the late afternoon at the summer solstice (Fig. 47) and its highlighting of the transition between the perfect hemisphere of the dome and the cylinder of the drum at noon on the equinox offer strong indications that the building could have continued to serve as a sundial after the rebuilding, even if this is not consistently evident in the present state of the building. ${ }^{196}$ Dio's second, preferred explanation of the building's name, that it resembled the heavens, may suggest that the gods were ordered by celestial hierarchy, which might fit recent cosmological interpretations of the interior architecture. ${ }^{197}$ The deities listed in Isidorus' Etymologies provide a possible order on this basis, but do not easily tally with the thirty-four statue niches in the building, and it would be hard to arrange them horizontally in a way that communicated this celestial hierarchy. ${ }^{198}$ Likewise, the twenty 'select gods' commended by Varro are hard to fit into the available spaces. ${ }^{199}$ If Mars and Venus were included in the main exedra, they cannot have been included among the deities of the other exedras. Moreover, the thirty-four wall niches, plus the three statues of the main exedra, provide for a group much larger than the twelve. A tentative reconstruction of the two curvilinear exedras which are the hierarchically secondary points of visual focus after the main apse, on the perpendicular axes of the building and likewise fronted by columns of pavonazzetto, could be based on prominent triads in Roman religion, such as the Capitoline triad of Jupiter, Juno and Minerva or the so-called Plebeian Triad of Ceres, Liber (Bacchus) and Libera (Proserpina). But it might be closer to the original planetary context of the building to envisage here triads expanded from the pairs of the Twelve Gods such as Apollo and Diana with their mother Latona and Jupiter and Juno with Cybele alongside Jupiter as co-guardian of Leo. ${ }^{200}$ This reconstruction still leaves it difficult to fit the remaining six of the Twelve Gods into the twenty spaces of the exedras on the diagonals. Of the four rectangular exedras on the diagonals with giallo antico screens, three could have been occupied by the three remaining pairs of 'Consenting Gods': Vulcan and Vesta; Neptune and Minerva; and Mercury and Ceres. Yet if there were five niches in each of these exedras it is difficult to see how this order could have been preserved. ${ }^{201}$ If three of these four exedras were each centred on one of these divine pairs, the positioning of Mars and Venus in the main exedra requires one triad to be added from the non-Olympians. Possible candidates include Bacchus, Hercules, the two Dioscuri, Castor and Pollux, and the nymph Juturna, but many more would be needed to fill the thirty-four niches, so

\footnotetext{
196 Hannah 2009: I 45-54 is cautious, but notes that any decorative scheme that might have marked, for example, a meridian line could have been lost since antiquity.

197 See Loerke I990; Wilson Jones 2000: I82-4. It was evident in the hemispherical dome; its five rows of twenty-eight coffers plausibly painted with stars on a blue background; the twenty-eight sections of the attic storey; and the division of the ground storey into sixteen sections, mirroring the division of the Etruscan sky.

198 Isid., Etym. 8.I I (Janus, at the door to the universe; Saturn and Jupiter, the furthest heavens and first principles; Neptune, Vulcan and Pluto, the elements; Mercury, Mars, Apollo and Diana, the lower planets; Ceres and Juno, gods of earth and air; and the inhabitants of the lower regions, Fauns, Genius, Parcae, Fortune, Fate, Furies, Nymphs, Heroes, Penates, Manes, Larvae, Incubi); cf. Chance I994: I.I42.

199 Aug., Civ. Dei 7.2.

200 Such a triad is found in the early Augustan temple of Palatine Apollo (Roccos I989), so it could plausibly be presented as consistent with the original Augustan scheme.

201 One could imagine each pair joined by other deities such as Hercules and Bacchus to fill the available niches. Hercules is included with other Olympians on the painted decoration of the compitum shrine on the Via dell'Abbondanza at Pompeii: Long 1987: 30-I. The companion of Ceres and Mercury might have been Cybele. In the votive relief from Marbach Cybele and Ceres appear together (with Jupiter and Juno) in the upper left register beside Mercury: Long I987: 25. Ovid (Ov, Am. 3.2.43-57) includes the Dioscuri in a procession of gods at the Circus, and their prominent temples at Rome gave them a claim to be included.
} 
one should perhaps think in terms of a mass of gods from the lower regions such as those listed by Isidorus.

An alternative reconstruction, therefore, would be to place eight of the Twelve in the aedicules around the rotunda. One might think that the planetary gods themselves should be within the reserved spaces of the exedras, leaving the detached aedicules for imperial statues as some have assumed were in the rotunda in the fourth century when Constantius II visited the building, if not in Hadrian's time. ${ }^{202}$ However, this is based on a misreading of Ammianus Marcellinus' account of Constantius' visit. ${ }^{203}$ Alternatively, the aedicules might appear well suited to standing or seated images of ancillary divine entities such as those that appear on Hadrian's coinage. ${ }^{204}$ Yet these have little claim to be present in a Pantheon of essentially astrological meaning. Moreover, the spatial prominence of the aedicules within the space of the rotunda, their greater height and depth by comparison with the wall niches of the exedras, allowing them to accommodate larger figures, and the porphyry columns that would originally have framed these, argue in favour of these being occupied by eight of the twelve planetary gods. That would leave two of the Twelve, perhaps Apollo and Diana or Jupiter and Juno, to stand at the centre of the curvilinear niches. That is as much as one can say about the organization of divine statuary in the Pantheon. As John North has warned, 'trying to arrange the Roman gods in any kind of authoritative overall sequence belongs to the efforts of modern scholarship, not to any ancient ritual order to which we can appeal'.205 That may seem less immediately obvious for a building with an astrological rôle, where the position of the images could potentially relate to the movements of the heavens; but the layout of the Pantheon is too rigid for statue positions to correspond directly with astronomical realities (Fig. 35 )..$^{206}$

The statuary was the main focus of the restoration of A.D. 202 witnessed by Dio. Few changes to the structure of the building are identifiable. The central area of the Campus Martius does not seem to have been affected by the fire of A.D. I9I. ${ }^{207}$ Perhaps some consolidation was needed to the rotunda after eighty years of subsidence. Yet the inscription on the architrave of the portico claims nothing more than that the building had fallen into disrepair, damaged or 'worn by the passage of time (vetustate corruptum)'.208 Some years ago I suggested that the claim of the inscription was therefore not borne out by the reality of work done and was potentially misleading. ${ }^{209}$ Yet the emphasis of the inscription is somewhat different and can be construed in such a

202 Fourth century: La Rocca 2015: 78 ('the emperors'); Hadrian: Opper 2008: II9 ('members of the imperial family').

203 Amm. Marc. I6.Io.I 4: 'Pantheum velut regionem teretem speciosa celsitudine fornicatam: elatosque vertices [qui] scansili suggestu consulum [consurgunt] et priorum principum imitamenta portantes'; 'the Pantheon like a rounded city-district, vaulted over in lofty beauty; and the exalted heights which rise with platforms to which one may mount, and bear the likenesses of former emperors'. The second phrase seems to refer, not to the Pantheon, but to the columns of Trajan and other emperors.

204 In the first year of Hadrian's reign the reverses of issues included Fortuna (seated), Pax (standing), Pietas (standing), Concordia (seated), Felicitas (standing) and Salus (standing): BMC Hadrian 68-73, 77-83, 88-96; a standing Fides is not dated to a specific year of Hadrian's reign: BMC Hadrian 627-32.

205 North 2010: 46.

206 For example, there would be no space for Aesculapius Eshmun, the half millennial anniversary of whose arrival in Rome was commemorated in A.D. 207, or for Dea Dia, the goddess of the Arval sanctuary, to whom Calpurnius Piso sacrificed at the Pantheon in A.D. 59. But the Pantheon was chosen in A.D. 59, not because there was a cult of Dea Dia there, but because of the associations of the site with the Gens Iulia (Scheid I990: 46I). Other notable absentees include Janus and Pluto.

207 In the Circus Flaminius to the south the Porticus Octaviae was damaged: Carandini 20I 2: I.523.

208 Parallels for this phrase suggest simple wear and tear, rather than any more substantial structural failings, and specifically put this down to the process of time, rather than any external cause; e.g. CIL XIV.2088 = ILS 30 I 6 (votive offerings in the sanctuary at Lanuvium).

209 Thomas and Witschel I992: I35. 
way that it did not wildly exaggerate the real contribution of the patrons. ${ }^{210}$ It states, quite literally, that the work of Severus and Caracalla was a restoration of the Pantheon cum omni cultu. ${ }^{211}$ This phrase is usually translated as 'with all the decoration'. Yet the proper meaning of the word cultus is 'religious worship'. The restoration by Severus and Caracalla involved not just replacing decorative or honorific statuary, but renewing functioning religious icons. ${ }^{212}$ That should imply at least the principal cult images of not just the preceding, Trajanic-Hadrianic structure, but of Agrippa's original building.

The fact that only cosmetic changes were involved did not make it less significant for Severus. Two years after the Severan restoration of the Pantheon, in A.D. 204, Manilius Fuscus, the master of the college of quindecimviri, proposed the Secular Games of that year to the Senate. In his speech he used a virtually identical phrase with unambiguous religious force:

Inter 1[aetitias] et ga[ud]ia generis / huma[ni ad gratias agendas prae]sentium bonorum et ad spem futur[orum curandum vobis e]st p.c. utei saeculari[a nunc te]mporis ratione poscente im[minentia $\mathrm{t}$ ]ot gen[it]alibus prosper[a] / com... s[ (-22-) sollem]nia in annum decernatis sumptusque communi e[xpensa f]ieri iubeatis omnique cultu adq[ue] veneratione immor[talium pro secu]rita[te] adque aeterni/t[ate imperii sa]nctissimo[s loco]s ag[e]ndis habe[n]disque gratia frequentetis, ut p[osteris dii] immortales referant, quae maior[e]s nostri condiderunt qu[aeque cum maior]ibu[s ante]a / [etiam temporib]us no[s]tris [concesse]runt.

Among the joys and pleasures of the human race you must take care to give thanks for the present good fortunes and for hope for the future, so that the imminent secular festival, favourable for so many fruitful ventures, as the reason of time demands, ... you should decree solemn rites for a year and order expenditures to be made at public cost, and you should, with all worship and veneration of the immortal gods, for the security and eternity of the empire, frequent the most sacred sites, for the rendering and giving of thanks, so that the immortal gods may pass on to the future generations what our ancestors have built up and the things which they have granted both to our ancestors previously and to our own times as well. ${ }^{213}$

To judge from the surviving fragments of this decree, the Pantheon played no part in the procession of A.D. 204, although one would not expect it to have done so, as it had previously only been used as a location for the indictio. Yet it could certainly be considered among the 'most sacred sites (sa]nctissimo[s loco]s)' of the city, and re-installation of the divine images of cult in Agrippa's building, restored under Trajan and Hadrian, was of the highest importance to Severus. As others have emphasized, divine support was central to the legitimation of the new reign, and this was above all

\footnotetext{
210 For valid criticisms of the original argument along these lines, see Fagan I996 and Cooley 201 2: 45 .

211 This statement of continuity is one argument against the possibility that the eight aedicules contained statues of the Divi, the deified emperors, since, after Augustus, only Claudius, Vespasian, Titus and Trajan could have been in place in the Hadrianic structure; Hadrian, Antoninus Pius and Marcus Aurelius could have brought the total to eight under Severus, but it seems undisputed that Augustus' statue stood only in the porch, and, given that, it is unlikely that his successors would have been in the interior.

212 cf. CIL VI.332 (a temple of Hercules Victor outside the Porta Portuensis, consecrated cum omni cultu by P. Plotius Romanus, cos. suff. c. A.D. 223); II.3I37 (a shrine at Falerii restored cum omni cultu et instrumento, 'with all its cult statuary and religious equipment'). The religious meaning of a similar phrase is insistent in the restoration of the Portico of the Consenting Gods in A.D. 367 by the Urban Prefect Vettius Agorius Praetextatus: '[deorum c] onsentium sacrosancta simulacra cum omni lo[ci totius adornatio]ne cultu in [formam antiquam restituto]' (CIL VI.IO2 $=I L S 4003$ ). Note, however, that in the building inscription for the Baths of Diocletian (CIL VI.r I3O) the phrase omni cultu seems to refer to decoration alone.

213 CIL VI.32326.2 I-5 (line 23: 'omnique cultu adque veneratione'). Translation from Birley I972: I57; my emphasis.
} 
manifested in the visual presence of the divine. ${ }^{214}$ Nowhere else in Rome had so many gods as the Pantheon, so it was the obvious place of resort for seeking divine sanction. Perhaps Severus' own dii auspices, Hercules and Bacchus, ${ }^{215}$ were even present in the exedras alongside the older 'Consenting Gods' of Rome and the divinities that afforded emperors protection and success.

Agrippa's Pantheon and its Trajano-Hadrianic replacement were not dedicated to public cults. The building did not experience the wholesale desecration applied to state temples. It survived into the seventh century in good structural condition, inviting its consecration as a Christian church. ${ }^{216}$ Later accounts of its conversion under Phocas and Boniface IV insist that it needed to be cleansed of the 'filth' of its multitude of demons before it could be converted to Christian use. ${ }^{217}$ Yet if, as moderns believe, its statuary had already disappeared by then as a result of the degeneration of the area in the preceding centuries, that would explain why it was so easily converted. In the sixteenth century only one bust remained. This Cybele had given rise to the medieval tradition that the building was the result of a vow to her by Agrippa, who, allegedly, placed a gilded statue 'on top of the temple, over the hole, and put over it a wonderful cover of gilded bronze', the famous pine cone now in the Vatican Belvedere Court. ${ }^{218}$ It also encouraged the belief that the building dedicated by Boniface to Mary 'mother of all saints' had originally been dedicated 'on the calends of November in honour of Cybele mother of the gods'. ${ }^{219}$ But by the fourteenth century a popular reading of Pliny's Natural History caused a view to spread that the Pantheon had been dedicated by Agrippa to Jupiter Ultor. ${ }^{220}$ Antiquarians in the early sixteenth century reconciled this opinion with the medieval tradition in a spurious combined dedication 'to Jupiter Ultor, Cybele and all the gods'. ${ }^{221}$ Only in the I 830 , after the young classical scholar Ludwig von Jan (I807-I869) rediscovered the Bamberg manuscript of Pliny ('B'), could those manuscripts which transmitted the word ultori finally be dismissed. ${ }^{222}$ Whether the head of Cybele remaining in the first chapel of the sixteenth-century Pantheon had come from the multitude of divine images in the original building cannot be proved. As we have seen, there is some reason to believe that the goddess belonged to the statuary of the Hadrianic rotunda, perhaps even alongside Jupiter and Juno as astrological co-guardian of Leo. As for 'Jupiter Ultor', the appearance of the word ultori in two rather early

\footnotetext{
214 Rowan 20I2.

215 Rowan 20I 2: 4I-5.

216 Thunø 2015: 234, suggesting that its architectural differences from other temples at Rome facilitated its conversion to a church.

217 Bede, HE 2.4 (in Migne, PL xcv, col. 88); Paul. Diac., Hist. Langob. 4.36 (in MGH, Scriptores rerum langob. et italic., ed. L. Bethmann and G. Waitz (Hannover, I878), I28). See Emerick I998: I, 230 with n. I5I; Elsner 2003: 218.

218 Mirabilia Urbis Romae, in Valentini and Zucchetti I940-53, 3.35; Kinney 2005: 35.

219 Benedict the Canon, Mirabilia, Ch. XVI, trans. Fr. Morgan Nichols, The Marvels of Rome (London/Rome, I889), 46-9, in Davis-Weyer I986: I 58.

220 Pliny, $H N$ 36.24.I02. Followed, e.g., by Petrarch and, in an amended form ('Jupiter Victor'), by Pomponio Leto: Valentini and Zucchetti I946: I.233; 4.426. Schofield 2016: I24-5; Fane-Saunders 201 6: 57 with 339 n. I9. 221 Published in Albertini I 5 IO, Book 2, Ch. 2, fol. Liiii v, lines I3-27- fol. M r, lines I-2: 'Templum Pantheon dedicatum erat Iovi ultori \& Cybeli \& omnibus diis: nu[n]c vero deo aeterno \& Mariae Vir.[gini] \& omnibus Martiribus: vulgo sa[n]cta Maria Rotunda cum portico pulcherrima. M. Agrippae in frontispitio cuius visuntur cubitales litterae cum hac inscriptione s.[cilicet] M. AGRIPPA. F. L. COS. Tertium Fecit.' But this composite dedication had already been imagined a few years earlier by an anonymous Vitruvius manuscript in Ferrara: Schofield 2016: I24-5. Rejected by 'Publius Victor' [Giano Parrasio], De regionibus Urbis Romae libellus aureus ( $1503-4)$, who had demonstrated that neither Pantheon nor Iovi were found in the manuscripts, the reading was not abandoned as swiftly as Schofield suggests: Palladio still believed that the Pantheon was dedicated 'after Jupiter ... to all the Gods' (Quattro Libri, IV, Ch. 20).

222 Reeve 2007: I I I-I 2. Jan's conjecture diribitori, making sense of B's reading dilibitori, made sense of Pliny's text as referring to Agrippa's Diribitorium instead, and this reading was adopted by Julius Sillig in ${ }^{2} 836$ in his first complete edition of Pliny's work (Sillig I83 I-36: 5, 230).
} 
manuscripts still needs an explanation. ${ }^{223}$ I have argued that Agrippa's Pantheon was created as a vast sundial which included an assemblage of planetary divinities modelled on Hellenistic precedents, particularly at Antioch, and that it focused particularly on the 'Roman' gods of Mars and Venus and the newest star of the Deified Julius. This essential focus continued after the Hadrianic and Severan restorations. The inclusion of the Deified Julius into this cosmic system was key to early Augustan ideology, when, following Octavian's recent victory at Actium, Mars still had the function of 'the Avenger (Ultor)' of Caesar. The manuscript reading ultori Pantheon, then, may betray how some early medieval readers of Pliny still recalled this original association of the building. ${ }^{224}$

\section{Durham University \\ e.v.thomas@durham.ac.uk}

\section{ABBREVIATIONS}

BMC Mattingly, H. 1923-64: Coins of the Roman Empire in the British Museum (6 vols), London RIC I ${ }^{2}$ Sutherland, C. H. V., and Carson, R. A. G. (eds) I984: The Roman Imperial Coinage, Vol. I, From 3 I B.C. to A.D. 69 (2nd edn), London

RIC II Mattingly, H., and Sydenham, E. A. I926: The Roman Imperial Coinage, Vol. II, Vespasian to Hadrian, London

\section{BIBLIOGRAPHY}

Albertini, F. I 5 Iо: Opusculum de mirabilibus novae et veteris urbis Romae, Rome

Amici, C. M. I991: Il Foro di Cesare, Florence

André, J. (ed.) I987: Ovide Tristes, Paris

Anon. I 867: 'Wissenschaftliche Vereine', Archäologischer Anzeiger, no. 220 (April I 867), included within Archäologische Zeitung 25, 49-62

Anon. I888: 'Sitzungsprotocolle', Mitteilungen des Deutschen Archäologischen Instituts: Römische Abteilung 3, 93-100

Ansel, C. 20I2: 'Le relief de Carthage, un remploi iconographique partiellement modifié', Cahiers d'histoire 31.2, I33-55

Arafat, K. W. I996: Pausanias' Greece: Ancient Artists and Roman Rulers, Cambridge

Ashby, T. I908: 'VII. The Villa d'Este at Tivoli and the collection of classical sculptures which it contained', Archaeologia 61, 219-56

Babelon, E. I963: Description historique et chronologique des monnaies de la république romaine vulgairement appellées monnaies consulaires, Bologna

Barkan, L. I999: Unearthing the Past: Archaeology and Aesthetics in the Making of Renaissance Culture, New Haven/London

Barresi, P. 2003: Province dell'Asia Minore: costo dei marmi, architettura pubblica e committenza, Rome

Bartoli, A. I9I4-22: I monumenti antichi di Roma nei disegni degli Uffizi di Firenze, 6 vols and text vol., Florence.

Bartsch, T. 2003: 'Francisco de Holanda und der Koloss von Barletta. Zum Antikenstudium nicht-italienischer Künstler der Renaissance "fuori Roma”, Pegasus. Berliner Beiträge zum Nachleben der Antike 4, I I 5-58

\footnotetext{
223 The two manuscripts with this reading in Eichholz's Loeb apparatus (I962: 80 n. 4) are 'R' (Florence, Ricc. 488 , mid-ninth century) and 'd' (Paris B. N. Lat. 6797, twelfth century); cf. Sillig I 83 I-6: 230 . For the dates of the manuscripts, see Reeve 2007: I 25-3I.

224 I am grateful to audiences at Durham and Oxford where earlier versions of this paper were presented and to the anonymous readers for JRS for their comments.
} 
Bartsch, T. 2007: 'Kapitell. Colosseum. Überlegungen zu Heemskercks Bildfindungen am Beispiel von fol. $28 \mathrm{r}$ des römischen Zeichnungsbuches', in K. Schade et al. (eds), Zentren und Wirkungsräume der Antikerezeption: zur Bedeutung von Raum und Kommunikation für die neuzeitliche Transformation der griechisch-römischen Antike. Festschrift für Henning Wrede, Münster, 27-38

Bartsch, T. 20I2: 'Praktiken des Zeichnens "drinnen" und "draußen". Zu van Heemskercks römischen Itinerar', in Bartsch and Seiler 201 2, 25-48

Bartsch, T., and Seiler, P. (eds) 20I2: Rom Zeichnen. Maarten van Heemskerck 1532-1536/37, Berlin

Birley, A. R. I972: The African Emperor: Septimius Severus, London

Boardman, J. 2009: The Marlborough Gems formerly at Blenheim Palace, Oxfordshire, Oxford

Bober, P. P., and Rubinstein, R. 1986: Renaissance Artists and Antique Sculpture. A Handbook of Sources, London/Oxford

Bober, P. P., and Rubinstein, R. 2010: Renaissance Artists and Antique Sculpture. A Handbook of Sources (2nd edn), London

Briggs, C. C. I930: 'The "Pantheon" at Ostia (and its immediate surroundings)', Memoirs of the American Academy at Rome 8, I6I-9

Burnett, A. M. I977: 'The authority to coin in the late Republic and early Empire', Numismatic Chronicle, 7 th series, $17,37-63$

Bury, J. B. I98I: 'Catalogue of Francisco de Holanda's writings, drawings, paintings and architectural designs', in Two Notes on Francisco de Holanda, London, 29-45

Cafà, V. 2004: 'I Massimo tra quattro e cinquecento: affari e ideali di una famiglia romana', Rivista storica del Lazio I2, 3-50

Cagiano de Azevedo, M. I95 I: Le antichità di Villa Medici, Rome

Carandini, A. 201 2: Atlante di Roma antica, 2 vols, Milan

Cary, E., and Foster, H. B. I9 17: Dio Cassius, Roman History, Vol. VI: Books 5I-55, Loeb Classical Library 83 , Cambridge, MA

Chance, J. I994: Medieval Mythography, Vol. I, From Roman North Africa to the School of Chartres, A.D. 433-II77, Gainsville, Fla.

Christian, K. Wren 20I2: 'For the delight of friends, citizens, and strangers: Maarten van Heemskerck's drawings of antiquities collections in Rome', in Bartsch and Seiler 20I2, I 29-54

Coarelli, F. I983: 'Il Pantheon, l'apoteosi di Augusto e l'apoteosi di Romolo', Città e architettura nella Roma imperiale, Analecta Romana Instituti Danici Io, 4 I-6

Conti, G. I970: Decorazione architettonica della "Piazza d'Oro" a Villa Adriana, Rome

Cook, A. B. I9I4-40: Zeus, a Study in Ancient Religion, 3 vols, London

Cooley, A. E. 20I 2: The Cambridge Manual of Latin Epigraphy, Cambridge

Cooper, R. 2013: Roman Antiquities in Renaissance France, I5I5-65, Farnham

Crawford, M. H. 1974: Roman Republican Coinage, London

Daly Davis, M. (ed.) I 994: Archäologie der Antike: aus der Beständen der Herzog August Bibliothek I 500-I700, Wiesbaden

Davis-Weyer, C. I986: Early Medieval Art, 300-I 150: Sources and Documents, Toronto

de Fine Licht, K. I968: The Rotunda in Rome: a Study of Hadrian's Pantheon, Copenhagen

DeLaine, J. 2015: 'The Pantheon builders: estimating manpower for construction', in Marder and Wilson Jones 201 5, I 60-92

Deswarte, S. I996: 'Francisco de Holanda', in J. Turner (ed.), The Dictionary of Art, London/ New York, 659-62

Donié, P. I996: Untersuchungen zum Caesarbild in der römischen Kaiserzeit, Hamburg

Doublet, G. I890: Museés de l'Algérie. Alger I, Paris

Dyggve, E. I94I: Ravennatum Palatium sacrum. La basilica ipetrale per ceremonie. Studii sull'architettura dei palazzi della tarda antichità, Copenhagen

Eichholz, D. E. I962: Pliny, Natural History, Vol. X: Books 36-37, Loeb Classical Library 4I9, Cambridge, MA

Elsner, J. 2003: 'Iconoclasm and the preservation of memory', in R. S. Nelson and M. Olin (eds), Monuments and Memory, Made and Unmade, Chicago, 209-3 I

Emerick, J. J. I998: The Tempietto del Clitunno near Spoleto (2 vols), University Park, PA

Erim, K. T., Reynolds, J., Wild, J. P., and Ballance, M. H. I970: 'The copy of Diocletian's Edict on Maximum Prices from Aphrodisias in Caria', Journal of Roman Studies 60, I 20-4I

Fabbrini, L. I961: 'Su una recente proposta di M. Claudio Marcello', Archeologia Classica I3, I 52-8 
Fagan, G. G. I996: 'The reliability of Roman rebuilding inscriptions', Papers of the British School at Rome 64, 8I-93

Fane-Saunders, P. 2016: Pliny the Elder and the Emergence of Renaissance Architecture, Cambridge

Fejfer, J. 2008: Roman Portraits in Context, Berlin/New York

Fensterbusch, C. (ed.) I964: Vitruv, Zehn Bücher über die Architektur. Vitruvii De Architectura libri decem, Darmstadt

Ferrea, L. 2002: Gli Dei di terracotta. La ricomposizione del frontone da Via di San Gregorio, Milan

Fishwick, D. I992: 'The statue of Julius Caesar in the Pantheon', Latomus 5 I.2 (April-June), 329-36

Fittschen, K. I976: 'Zur Panzerstatue in Cherchel', Jahrbuch des Deutschen Archäologischen Instituts 9I, I75-209

Francovich, G. de I970: Il Palatium di Teodorico a Ravenna e la cosidetta 'architettura' di Potenza, Rome

Fraschetti, A. I990: Roma e il principe, Bari

Frommel, C. L. I994: 'Introduction. The drawings of Antonio da Sangallo the Younger: history, evolution, method, function', in C. L. Frommel and N. Adams (eds), The Architectural Drawings of Antonio da Sangallo the Younger and his Circle, Vol. I, Fortifications, Machines, and Festival Architecture, New York/Cambridge, MA

Fullerton, M. D. I985: 'The Domus Augusti in imperial iconography of I3-I2 B.C.', American Journal of Archaeology 89.3 (July), 473-83

Fulvio, A. I 5 3 : Antiquaria Urbis, Rome

Furtwängler, A. I897: Sammlung Somzée: Antike Kunstdenkmäler, Munich

Galinsky, K. 1996: Augustan Culture: an Interpretive Introduction, Princeton, NJ

Ganzert, J. 1996: Der Mars-Ultor Tempel auf dem Augustusforum in Rom, Mainz

García, G. C. I987-88: 'Datos para el estudio del culto imperial en la Colonia Augusta Firma Astigi', Habis I 8-19, 365-8I

Gibbs, S. L. 1976: Greek and Roman Sundials, New Haven, CT

Godard, L. I857: 'Chronique', Revue Africaine. Journal des Travaux de la Société Historique Algérienne I, no. 6 (August I 857), 474-92

Godfrey, P., and Hemsoll, D. I986: 'The Pantheon: temple or rotunda?', in A. King and M. Henig (eds), Pagan Gods and Shrines of the Roman Empire, Oxford, 195-209

Gorski, G. J., and Packer, J. E. 20I 5: The Roman Forum. A Reconstruction and Architectural Guide, Cambridge

Gradel, I. 2002: Emperor Worship and Roman Religion, Oxford

Granger, F. 1932: 'The Greek origin of the Pantheon', Journal of the Royal Institute of British Architects 40, 57-6I

Granger, F. I933: 'Julius Africanus and the Library of the Pantheon', Journal of Theological Studies 34, I 57-6I

Granger, F. (ed.) 1934: Vitruvius, On Architecture, Vol. 2, Loeb Classical Library no. 280, Cambridge, MA/London

Granger, F. (ed.) I985: Vitruvius, On Architecture, Vol. 2 (4th reprint, gen. ed. F. H. Warmington), Loeb Classical Library no. 280, Cambridge, MA/London

Green, P. 1989: 'Caesar and Alexander: aemulatio, imitatio, comparatio', in P. Green, Classical Bearings: Interpreting Ancient History and Culture, Berkeley/Los Angeles/London, 193-209

Green, P. 2005: The Poems of Exile: Tristia and the Black Sea Letters, Berkeley, CA

Gruben, D., and Gruben, T. I997: 'Die Tür des Pantheon', Mitteilungen des Deutschen Archäologischen Instituts: Römische Abteilung I04, 3-74

Grueber, H. A. I910: Coins of the Roman Republic in the British Museum, London

Gsell, S. I 892: 'Le musée d'Alger', Revue africaine 36, 389-96

Gsell, S. I 899: 'Les statues du Temple de Mars Ultor à Rome', Revue Archéologique 33 34, 37-43

Gsell, S. I930: Histoire ancienne de l'Afrique du Nord (3rd edn), vol. 8, Paris

Hannah, R. 2009: Time in Antiquity, London/New York

Hansen, E. I960: La Piazza d'Oro e la sua cupola, Analecta Romana Instituti Danici suppl. I, Copenhagen

Harder, A. 20I 2: Callimachus Aetia: Introduction, Text, Translation, and Commentary, Oxford

Haskell, F., and Penny, N. I98 I: Taste and the Antique. The Lure of Classical Sculpture, I500-I900, New Haven/London

Heenes, V. 2003: Antike in Bildern. Illustrationen in antiquarischen Werken des I6. und I7. Jabrhunderts, Stendal 
Helbig, W. (ed.) I9I 2: Führer durch die öffentlichen Sammlungen klassischer Altertümer in Rom ${ }^{3}$ (with W. Amelung, E. Reisch and F. Weege), 2 vols, Leipzig

Herrmann, J. J. Jr., Attanasio, D., Tykot, R. H., and van den Hoek, A. 20I 2: 'Characterization and distribution of marble from Cap de Garde and Mt. Filfila, Algeria', in A. Gutiérrez Garcia-Moreno, P. Lapuente Mercadal and I. Rodà de Llanza (eds), Interdisciplinary Studies on Ancient Stone. Proceedings of the IX Association for the Study of Marbles and Other Stones in Antiquity (ASMOSIA) Conference (Tarragona 2009), Tarragona, 300-9

Heslin, P. J. 2015: The Museum of Augustus. The Temple of Apollo in Pompeii, the Portico of Philippus in Rome, and Latin Poetry, Los Angeles, CA

Hülsen, C., and Egger, H. I9I3-I6: Die römischen Skizzenbücher von Marten van Heemskerck im Königlichen Kupferstichkabinett zu Berlin, Berlin

Hurst, H. I975: 'Excavations at Carthage 1974: first interim report', Antiquaries Journal 55, I I-40

Iara, K. 20I 5: Hippodromus Palatii: die Bauornamentik des Gartenhippodroms im Kaiserpalast auf dem Palatin in Rom, Wiesbaden

Jeffreys, E., Jeffreys, M., and Scott, R. (eds) I986: The Chronicle of John Malalas, Melbourne

Jentel, M.-O. I98I: 'Aigyptos', in Lexicon Iconographicum Mythologiae Classicae vol. I.I, Zurich/ Munich, 379-8I

Johansen, F. S. I967: 'Antichi ritratti di C. Giulio Cesare nella scultura', Analecta Romana Instituti Danici 4, 7-68

Jones, H. S. I9I 2: A Catalogue of the Ancient Sculptures Preserved in the Municipal Collections of Rome. Vol. I. The Sculptures of the Museo Capitolino, Oxford

Jucker, H. 1976: 'Die Prinzen auf dem Augustus-Relief in Ravenna', in P. Ducrey et al. (eds), Mélanges d'histoire ancienne et d'archéologie offerts à Paul Collart, Lausanne, 237-67

Kellum, B. I997: 'Concealing/revealing: gender and the play of meaning in the monuments of Augustan Rome', in T. Habinek and A. Schiesaro (eds), The Roman Cultural Revolution, Cambridge, I $58-8$ I

Kiilerich, B. 2000: 'Representing an emperor: style and meaning on the Missorium of Theodosius I', in M. Almagro-Gorbea, J. M. Alvarez Martínez, J. M. Blázquez Martínez and S. Rovira (eds), El disco de Teodosio, Madrid, 273-80

Kinney, D. 2005: 'Spolia', in W. Tronzo (ed.), St Peter's in the Vatican, Cambridge/New York, I6-47

Kleiner, D. E. E. 2009: Cleopatra and Rome, Cambridge, MA

Kondratieff, E. 20I0: 'The Urban Praetor's tribunal in the Roman Republic', in F. de Angelis (ed.), Spaces of Justice in the Roman World, Leiden/Boston, 89-1 26

Koortbojian, M. 2013: The Divinization of Caesar and Augustus, Cambridge

Kousser, R. M. 2007: Hellenistic and Roman Ideal Sculpture: the Allure of the Classical, New York/ Cambridge

Kraft, K. I952-3: 'Der goldene Kranz Caesars', Jahrbuch für Numismatik und Geldgeschichte 3-4, 7-97

Kraft, K. I967: 'Der Sinn des Mausoleums des Augustus', Historia I6, I89-206

Kraus, T. I964: 'Mars Ultor, Münzbild und Kultbild', in E. Homann-Wederking and B. Segall (eds), Festschrift Eugen von Mercklin, Waldsassen, 66-75

Kraus, T. I979: 'Zum Mars Ultor-Relief in Algier', in G. Kopcke and M. B. Moore (eds), Studies in Classical Art and Archaeology: a Tribute to Peter Heinrich von Blanckenhagen, Locust Valley, 239-45

Kruse, T. I992: 'Zwei Denkmäler der Antigoniden in Olympia: eine Untersuchung zu Pausanias 6.I6.3', Mitteilungen des Deutschen Archäologischen Instituts: Athenische Abteilung 107, 273-93

Lafréry, A. 1575: Speculum Romanae Magnificentiae, omnia fere quaecunq. in vrbe monvmenta extant, partim ivxta antiquam, partim ivxta hodiernam formam accuratiss. delineata repraesentans, Rome

Lanciani, R. I902: Storia degli scavi di Roma e notizie intorno le collezioni romane di antichità, Vol. I, Rome

Langlotz, E. I954: 'Zwei römische Terrakottaköpfe', in R. Lullies (ed.), Neue Beiträge zur klassischen Altertumswissenschaft. Festschrift zur 60. Geburtstag von B. Schweitzer, Stuttgart, 3 I I-I 8

La Rocca, E. 20I 5: 'Agrippa's Pantheon and its origin', in Marder and Wilson Jones 201 5, 49-78

Lazzaro, C. I99I: 'The visual language of gender in garden sculpture', in M. Migiel and J. Schiesari (eds), Refiguring Women: Perspectives on Gender and the Italian Renaissance, Ithaca, NY, 7III 3 
Loerke, W. C. I990: 'A rereading of the interior elevation of Hadrian's Rotunda', Journal of the Society of Architectural Historians 49, no. I, 22-43

Long, C. R. 1987: The Twelve Gods of Greece and Rome, Leiden/New York

L'Orange, H. P. I932: 'Le statue di Marte e Venere nel Tempio di Marte Ultore sul Foro di Augusto', Symbolae Osloenses II, 94-9

Ma, J. 2013: Statues and Cities. Honorific Portraits and Civic Identity in the Hellenistic World, Oxford

MacCormack, S. G. 1981: Art and Ceremony in Late Antiquity, Berkeley, CA

MacDonald, W. L. I976: The Pantheon: Design, Meaning, and Progeny, Cambridge, MA

MacDonald, W. L., and Pinto, J. A. I995: Hadrian's Villa and its Legacy, New Haven

Maiuro, M. 20I0: 'What was the Forum Iulium used for? The Fiscus and its jurisdiction in first-century C.E. Rome', in F. de Angelis (ed.), Spaces of Justice in the Roman Empire, New York, I89-22I

Marder, T. A., and Wilson Jones, M. (eds) 2015: The Pantheon. From Antiquity to the Present, Cambridge

Márquez, C. 2003: 'Los restos romanos de la calle Mármoles en Sevilla', Romula 2, I27-48

Matheson, S. B., with J. J. Pollitt, 1994: An Obsession with Fortune. Tyche in Greek and Roman Art, New Haven, CT

Mattern, T. I995: 'Segmentstab-Kanneluren. $\mathrm{Zu}$ Entwicklung und Verbreitung eines Bauornamentes', Boreas. Münstersche Beiträge zur Archäologie 17, 57-76

Mattingly, H. 1923: Coins of the Roman Empire in the British Museum, vol. I, Augustus to Vitellius, London

Matz, F. I960: Review of A. Adriani, Divagazioni intorno ad un coppia paesistica del Museo di Alessandria (Rome, 1959), in Gnomon 32, 289-97

McCulloh, J. M. I980: 'From Antiquity to the Middle Ages: continuity and change in papal relic policy from the 6th to the 8th century', in E. Dassmann and K. Suso (eds), Pietas. Festschrift für Bernhard Kötting, Münster, 3 I 2-24

McKenzie, J. S., and Reyes, A. T. 20I3: 'The Alexandrian Tychaion: a Pantheon?', Journal of Roman Archaeology 26, 36-52

Mikocki, T. I995: 'Sub specie deae': les impératrices et princesses romaines assimilées à ses déesses. Etude iconologique, Rome

Millar, F. 1964: A Study of Cassius Dio, Oxford

Mommsen, T. I884: 'Der Denar des Q. Salvidienus und die Schätze von Peccioli und Metz', Zeitschrift für Numismatik I I, 7I-84

Montagu, J. I989: Roman Baroque Sculpture: the Industry of Art, New Haven/London

Müller, U. I982: 'Pyrrhos - zwei Ergänzungen und ein Nachspiel. Zur Statue des Mars Ultor im Kapitolinischen Museum', Bullettino della Commissione Archeologica Comunale di Roma 87 (I980-8I), I35-44

Naumann, R. 1979: Der Zeustempel in Aezanoi, Berlin

Newby, J. D. I938: A Numismatic Commentary on the Res Gestae of Augustus, Iowa City

Nissen, H. 1906: Orientation. Studien zur Geschichte der Religion, Berlin

North, J. 20I0: 'Pagan ritual and monotheism', in S. Mitchell and P. van Nuffelen (eds), One God: Pagan Monotheism in the Roman Empire, Cambridge, 34-52

Ohr, K. I991: Die Basilika in Pompeji, Berlin/New York

Oliver, A. Jr., 2002: 'The "Missorium of Theodosius", Journal of Roman Archaeology 1 5, 707-10

Opper, T. 2008: Hadrian: Empire and Conflict, London

Pasquali, S. I996: Il Pantheon: architettura e antiquaria nel Settecento a Roma, Modena

Pasquali, S. 2004: 'From the pantheon of artists to the pantheon of illustrious men: Raphael's tomb and its legacy', in M. Craske and R. Wrigley (eds), Pantheons: Transformations of a Monumental Idea, Aldershot, 35-56

Perry, M. 1972: 'The statuario publico of the Venetian Republic', Saggi e Memorie di Storia dell'Arte $8,75-\mathrm{I} 5 \mathrm{O}$

Piale, S. г833: Di un monumento interessantissimo della Basilica di S. Paolo, Rome

Pighi, G. B. 1965: De Ludis Saecularibus Populi Romani Quiritium (2nd edn), Amsterdam

Platner, S. B. I929: A Topographical Dictionary of Ancient Rome, completed and revised by T. Ashby, Oxford

Poinssot, M. I936: 'Inscriptions de Suo et de Maxula', Comptes-Rendus de l'Académie des Inscriptions (I936), 285. 
Pollini, J. I993: 'Ideology, rhetorical imagery and the creation of a dynastic narrative', in P. J. Holliday (ed.), Narrative and Event in Ancient Art, Cambridge, 258-98

Pollini, J. 20I 2: From Republic to Empire: Rhetoric, Religion, and Power in the Visual Culture of Ancient Rome, Norman, Oklahoma

Poulsen, V. I958: 'Portraits of Caligula', Acta Archaeologica 29, I75-90

Price, S. R. F. I984: Rituals and Power: the Imperial Cult in Asia Minor, Cambridge

Raeder, J. 1983: Die statuarische Ausstattung der Villa Adriana bei Tivoli, Frankfurt am Main

Rasch, J. J. I984: Das Maxentius-Mausoleum an der Via Appia in Rom, Mainz

Rasch, J. J. 1993: Das Mausoleum bei Tor de' Schiavi in Rom, Mainz

Reeve, M. D. 2007: 'The editing of Pliny's Natural History', Revue d'Histoire des Textes, n.s. 2, I07-79

Rich, J. W. I998: 'Augustus's Parthian honours, the temple of Mars Ultor and the arch in the Forum Romanum', Papers of the British School at Rome 66, 7I-I 28

Richter, G. M. A. I95I: Three Critical Periods in Greek Sculpture, Oxford

Rives, J. B. I995: Religion and Authority in Roman Carthage from Augustus to Constantine, Oxford

Roccos, L. Jones 1989: 'Apollo Palatinus: the Augustan Apollo on the Sorrento base', American Journal of Archaeology 93.4, 57I-88

Rockwell, P. 2003: 'The creative reuse of antiquity', in J. B. Grossman, J. Podany, and M. True (eds), History of Restoration of Ancient Stone Sculptures, Los Angeles, CA, 75-86

Roddaz, J.-M. I984: Marcus Agrippa, Rome

Romeo, I. I998: Ingenuus Leo. L'immagine di Agrippa, Xenia Antiqua 6, Rome

Rowan, C. 201 2: Under Divine Auspices, Cambridge

Rowland, I. D. (trans.) I999: Vitruvius. Ten Books on Architecture, with commentary and illustrations by T. N. Howe, Cambridge

Salviat, F. I960: 'Le bâtiment de scène du théâtre de Thasos', Bulletin de Correspondance Hellénique 84.I, 300-I 6

Scheid, J. I990: Le Collège des Frères Arvales: étude prosopographique du recrutement (69-304), Rome

Schenk von Stauffenberg, A. I93 I: Die romische Kaisergeschichte bei Malalas, Stuttgart

Schofield, R. (trans.) 2009: Vitruvius. On Architecture, London

Schofield, R. 2016: 'Notes on Leonardo and Vitruvius', in C. Moffatt and S. Taglialagamba (eds), Illuminating Leonardo: a Festschrift for Carlo Pedretti Celebrating his 70 Years of Scholarship (I944-2014), Leiden/Boston, I 20-33

Sillig, J. (ed.) I 83 I-36: C. Plini Secundi Naturalis Historia libri XXXVII, Leipzig

Simon, E. I963: 'Das neugefundene Bildnis des Gaius Caesar in Mainz', Mainzer Zeitschrift 58, I-I 8

Soubiran, J. (ed.) I969: Vitruve, De l'architecture, livre IX, Paris

Stemmer, K. I978: Untersuchungen zur Typologie, Chronologie und Ikonographie der Panzerstatuen, Berlin

Stewart, P. 2003: Statues in Roman Society: Representation and Response, Oxford

Stone, S. C. III I985: 'The imperial sculptural group in the Metroon at Olympia', Mitteilungen des Deutschen Archäologischen Instituts: Athenische Abteilung I00, 377-8I

Sumi, G. S. 2005: Ceremony and Power: Performing Politics in Rome between Republic and Empire, Ann Arbor, MI

Sutherland, C. H. V., and Carson, R. A. G. (eds) I984: Roman Imperial Coinage, Vol. I, From 3 I B.C. to A.D. 69 (2nd edn), London

Thacker, A. 2007: 'Rome of the martyrs: saints cults and relics, 4 th-7th century', in E. O'Carragain and C. Neuman de Vegvar (eds), Roma Felix. Formation and Reflections of Medieval Rome, Aldershot, I3-49

Thomas, E. V. 2007: Monumentality and the Roman Empire: Architecture in the Antonine Age, Oxford

Thomas, E. V. forthcoming: 'The Tychaion of Antioch between Seleucids and Rome', in preparation

Thomas, E. V., and Witschel, C. W. I992: 'Constructing reconstruction: claim and reality of Roman rebuilding inscriptions in the Latin West', Papers of the British School at Rome 60, I35-77

Thunø, E. 2015: 'The Pantheon in the Middle Ages', in Marder and Wilson Jones 2015, 23 I-54

Torelli, M. I982: Typology and Structure of Roman Imperial Reliefs, Ann Arbor, MI

Trunk, M. 2003: 'Early restorations of ancient sculptures in the Casa de Pilatos: sources and evidence', in J. B. Grossman, J. Podany, and M. True (eds), History of Restoration of Ancient Stone Sculptures, Los Angeles, CA, 25 5-64

Tuck, S. 20I 5: A History of Roman Art, Malden, MA 
Ulrich, R. B. I993: 'Julius Caesar and the creation of the Forum Iulium', American Journal of Archaeology 97, no. I (January), 49-80

Valentini, R., and Zucchetti, G. I940-53: Codice topografico della città di Roma, 4 vols, Rome

Veldman, I. M. 20I 2: 'The "Roman Sketchbooks" in Berlin and Maarten van Heemskerck's travel sketchbook', in Bartsch and Seiler 2012, I I-23

Vermeule, C. C. 1956: 'Hellenistic and Roman cuirassed statues', Berytus I3, I-82

Virgili, P., and Battistelli, P. I999: 'Indagini in piazza della Rotonda e sulla fronte del Pantheon', Bullettino della Commissione Archeologica Comunale di Roma Ioo, I37-54

Viscogliosi, A. 2000: I Fori Imperiali nei disegni d'architettura del primo cinquecento: ricerche sull'architettura e l'urbanistica di Roma, Rome

Visconti, E. Q. I790: Il Museo Pio-Clementino, III: Statue del Museo Pio-Clementino, Rome

Wace, A. J. B. I9 I0: 'The reliefs in the Palazzo Spada', Papers of the British School at Rome 5, I67200

Waga, H. I992: Vita nota e ignota dei Virtuosi al Pantheon. Contributi alla storia della pontificia academia artistica dei Virtuosi al Pantheon, Rome

Waldstein, C. I 887: 'Pasiteles and Arkesilaos, the Venus Genetrix and the Venus of the Esquiline', American Journal of Archaeology and the Fine Arts 3, I-I3

Weinstock, S. I971: Divus Julius, Oxford

Wilson Jones, M. 2000: Principles of Roman Architecture, New Haven/London

Wiseman, T. P. 1974: 'The Circus Flaminius', Papers of the British School at Rome 42, 3-26

Wuilleumier, P. I928: Musée d'Alger. Supplément, Paris

Zanker, P. 1987: Augustus und die Macht der Bilder, Munich

Zanker, P. I968: Forum Augustum: das Bildprogramm, Tübingen

Zanker, P. I988: The Power of Images in the Age of Augustus, Ann Arbor

Zanker, P. 2009: 'The irritating statues and contradictory portraits of Julius Caesar', in M. Griffin (ed.), A Companion to Julius Caesar, Oxford, 288-3 I4

Ziegenaus, O. 1981: Das Asklepieion von Pergamon. 3. Die Kultbauten aus römischer Zeit an der Ostseite des heiligen Bezirks, Altertümer von Pergamon I I.3, Berlin

Ziolkowski, A. 2007: 'Prolegomena to any future metaphysics on Agrippa's Pantheon', in A. Leone, D. Palombi and S. Walker (eds), Res Bene Gestae. Ricerche di storia urbana su Roma antica in onore di Eva Margareta Steinby, Lexicon Topographicum Urbis Romae Supplementum IV, Rome, 465-75 